\title{
SELEÇÃO DE FUNGOS ENTOMOPATOGÊNICOS E INFECÇÃO DE Hirsutella sp. EM Brevipalpus phoenicis (Geijskes, 1939)
}

\section{LuCiana SAvoi Rossi}

\author{
Dissertação apresentada à Escola Superior de \\ Agricultura "Luiz de Queiroz”, Universidade de São \\ Paulo, para obtenção do título de Mestre em \\ Ciências, Área de Concentração: Entomologia.
}

\section{PIRACICABA}

Estado de São Paulo - Brasil

Setembro - 2002 


\title{
SELEÇÃO DE FUNGOS ENTOMOPATOGÊNICOS E INFECÇÃO DE Hirsutella sp. EM Brevipalpus phoenicis (Geijskes, 1939)
}

\section{LUCIANA SAvoi Rossi}

Engenheiro Agrônomo

Orientador: Prof. Dr. SÉRGIO BATISTA ALVES

\author{
Dissertação apresentada à Escola Superior de \\ Agricultura "Luiz de Queiroz", Universidade de São \\ Paulo, para obtenção do título de Mestre em \\ Ciências, Área de Concentração: Entomologia.
}

PIRACICABA

Estado de São Paulo - Brasil

Setembro - 2002 


\section{Dados Internacionais de Catalogação na Publicação (CIP)} DIVISÃO DE BIBLIOTECA E DOCUMENTAÇÃO - ESALQ/USP

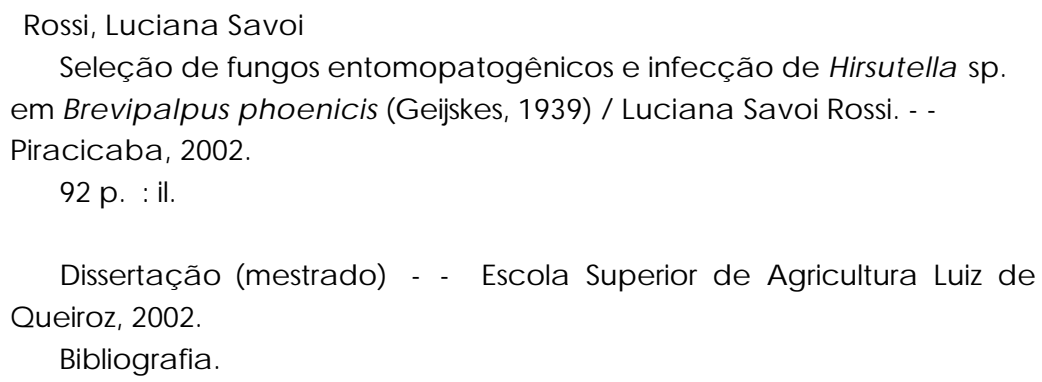

1. Ácaro de plantas2. Citric ultura 3. Fungos entomopatogênic os 4. Leprose 5. Vetores de doenças de planta I. Título

CDD 632.6542

\section{"Permitida a cópia total ou parcial deste documento, desde que citada a fonte - $\mathrm{O}$ autor"}


AOS MEUS PAIS, VIRGÍLIO E HELOISA ÀS MINHAS IRMÃS, BRUNA E LUÍSA

A HENRIQUE

OFEREÇO E DEDICO 


\section{AGRADECIMENTOS}

Ao Prof. Dr. Sérgio Batista Alves pela oportunidade para a realização deste trabalho e também pela confiança e amizade demonstrados à mim durante nosso convívio.

À bióloga Solange Aparecida Vieira pela amizade e auxílio na condução dos experimentos no laboratório.

A todos os colegas do laboratório de Patologia e Controle Microbiano de Insetos, Rogério (Phyto), Marco Tamai, Ricardo, Melissa, Adriana, Marcos Medeiros, Leonardo, Michelle, Marcel, Marcelo, Elizabeth e Daniella pela amizade e companheirismo.

Aos professores do Departamento de Entomologia (ESALQ/USP) pelos ensinamentos transmitidos durante o curso de pós-graduação.

Aos professores do curso de graduação em Engenharia Agronômica da Universidade Federal de São Carlos (Araras) em especial Maria Bernadette S. Campos e Dr. Newton Macedo pelos incentivos e contribuições para minha formação profissional.

Ao pessoal do laboratório de "Resistência de Artrópodes à Pesticidas" pelo fornecimento de frutos de laranja e população de ácaros que foram utilizados neste trabalho. 
Ao professor Dr. Celso Omoto pelas sugestões e correções do Summary.

Às professoras Dra. Marinéia de Lara Haddad e Dra. Clarice G. B. Demétrio e ao doutorando Adriano Ferretti pelo auxílio nas análises estatísticas.

À todas as pessoas da minha família, meus avós, tios (as), primos (as) que sempre estiveram presentes em todas as etapas de minha vida.

Às amigas Marcela Giotto Levy, Tatiele A. B. Fenilli e Ana Lia G. C. Parra pelo apoio.

A todos aqueles que sempre me incentivaram e me apoiaram.

Ao CNPq, pela bolsa de estudos que possibilitou a execução desse trabalho. 


\section{SUMÁRIO}

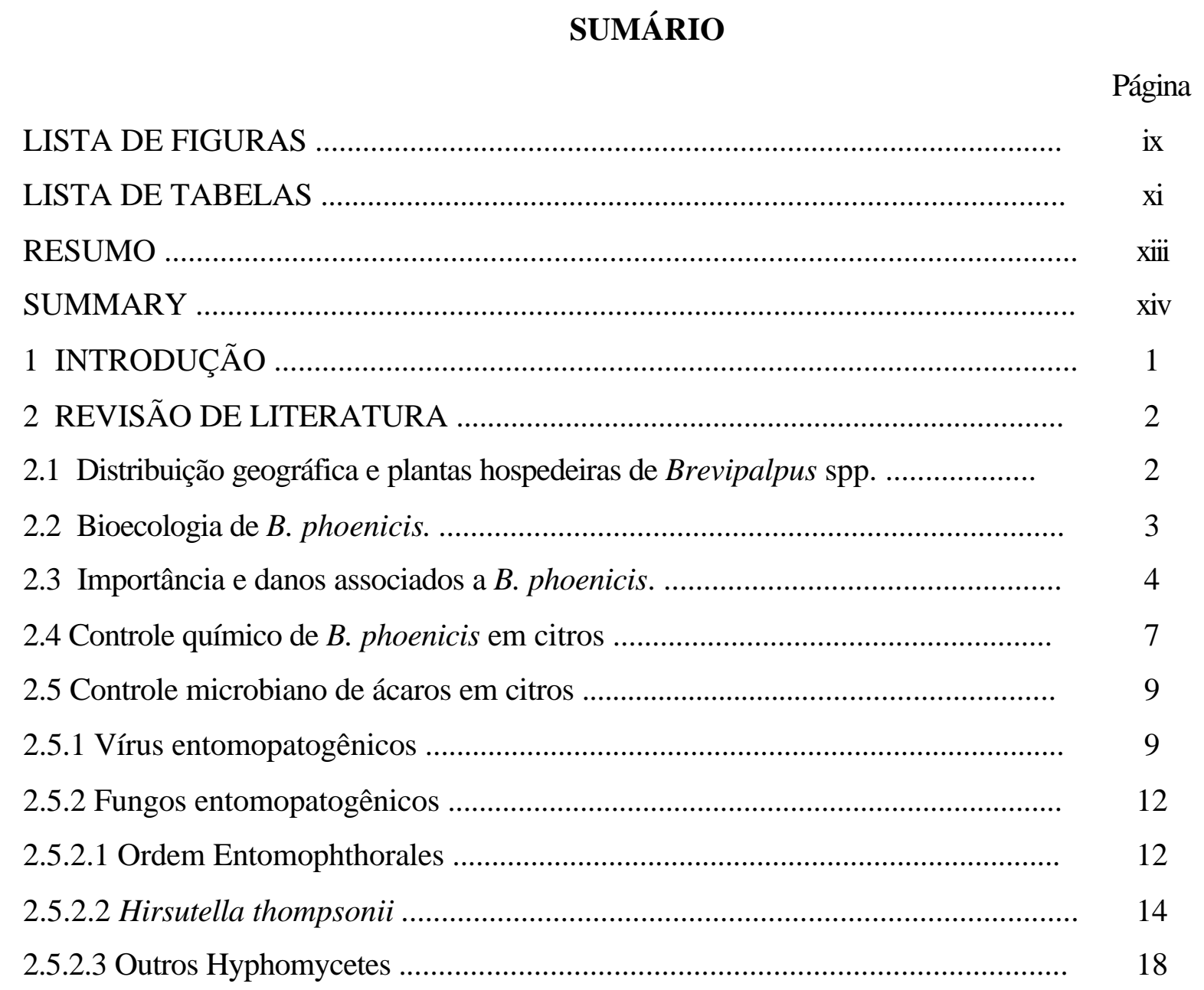

3 SELEÇÃO DE ISOLADOS DE FUNGOS ENTOMOPATOGÊNICOS PARA O CONTROLE DE Brevipalpus phoenicis .............................................................. 19

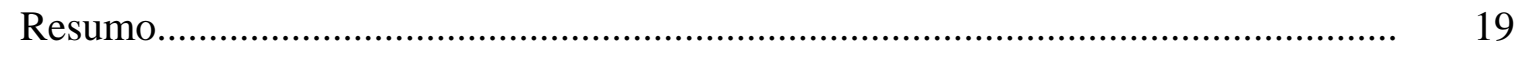

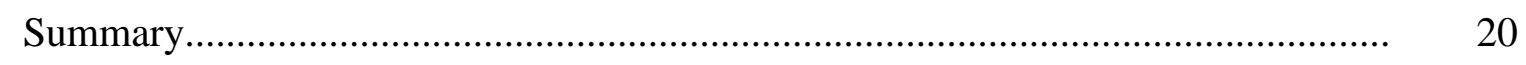

3.1 Introdução .............................................................................................. 21

3.2 Material e Métodos................................................................................... 22 
3.2.1 Criação e manutenção de B. phoenicis em laboratório ..................................... 22

3.2.2 Seleção de isolados para o controle de B. phoenicis ........................................ 23

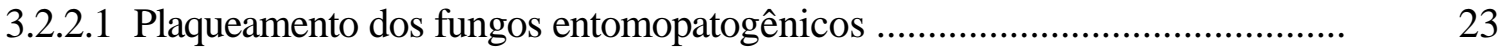

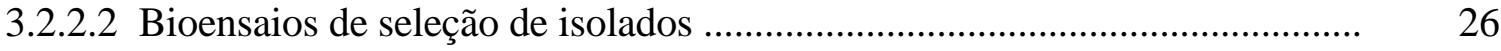

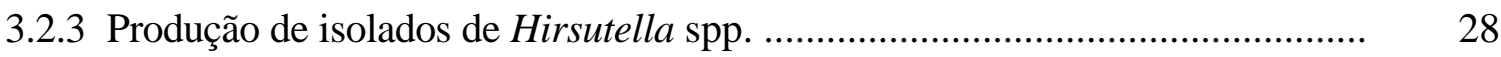

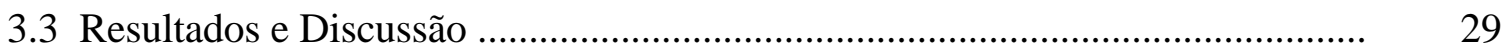

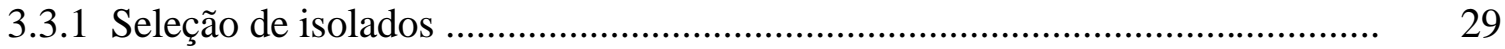

3.3.2 Produção de isolados de Hirsutella spp. ...................................................... 40

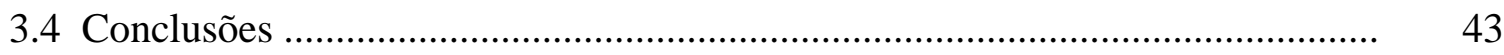

4 CIClO BIOLÓGICO E TRANSMISSÃO HORIZONTAL DE Hirsutella sp.

EM Brevipalpus phoenicis ......................................................................... 45

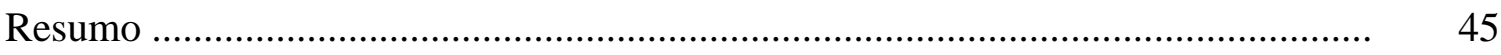

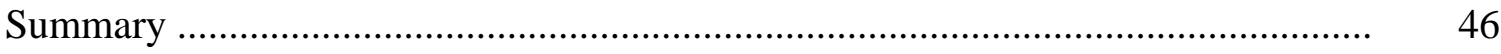

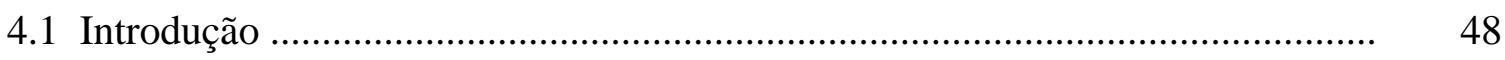

4.2 Material e Métodos .................................................................................... 49

4.2.1 Ciclo biológico de Hirsutella sp. sobre B. phoenicis ................................... 49

4.2.2 Transmissão horizontal de Hirsutella sp. entre adultos de $B$.

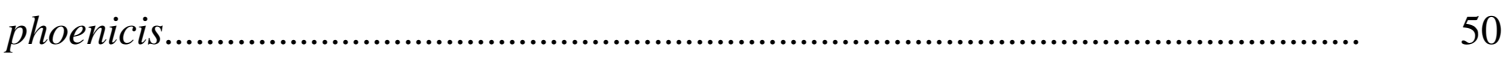

4.2.2.1 Transmissão horizontal de Hirsutella sp. entre cadáveres e adultos vivos de

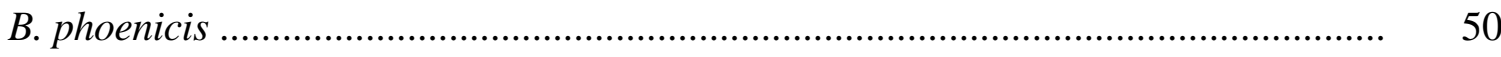

4.2.2.3 Transmissão horizontal de Hirsutella sp. para adultos de B. phoenicis à partir de substrato contaminado .................................................................... 51

4.3 Resultados e Discussão ........................................................................... 52

4.3.1 Etapas do ciclo biológico de Hirsutella sp. sobre B. phoenicis ...................... 52

4.3.2 Transmissão horizontal de Hirsutella sp. entre cadáveres e adultos vivos de

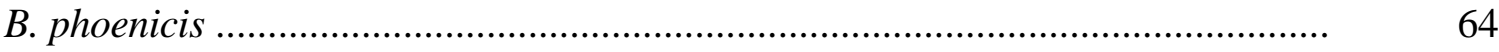

4.3.3 Efeito residual de Hirsutella sp. em adultos de B. phoenicis a partir de

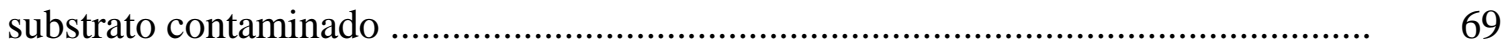

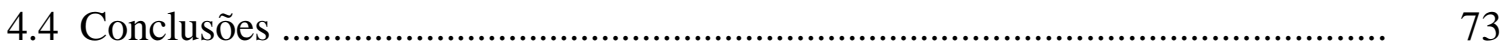


5 CONCLUSÕES GERAIS

REFERÊNCIAS BIBLIOGRÁFICAS................................................................. 


\section{LISTA DE FIGURAS}

Página

1 Bandeja contendo frutos utilizados para a criação de Brevipalpus phoenicis em laboratório (ESALQ/USP)

2 Arenas de folhas de citros utilizadas nos bioensaios de seleção de isolados para Brevipalpus phoenicis

3 Porcentagem de mortalidade corrigida de Brevipalpus phoenicis inoculados com diferentes isolados de fungos entomopatogênicos em dois dias de avaliação.

4. Mortalidade acumulada e corrigida de Brevipalpus phoenicis, inoculados com

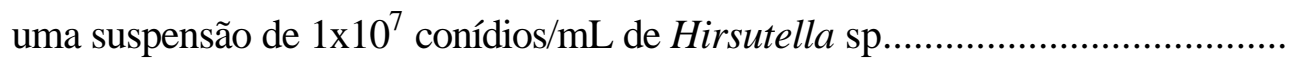

5 Detalhe de hifas e conidióforos de Hirsutella sp. emergindo de abertura anal de Brevipalpus phoenicis (Aumento: 40 vezes)

6 Etapas do ciclo biológico de Hirsutella sp. em adultos de Brevipalpus phoenicis.

7 Detalhes de Brevipalpus phoenicis. A) Adulto. B) Detalhe do ovo. C) Adultos agregados sobre a folha de citros 
8 Adesão de conídios de Hirsutella sp. ao corpo de Brevipalpus phoenicis (0 haa). A) Presença de conídios na folha e tarso do ácaro. B) Presença de conídios aderidos ao tegumento do ácaro

9 Início da germinação de Hirsutella sp. sobre Brevipalpus phoenicis (6 haa). A) Conídio presente no gnatossoma com aparente formação de apressório. B) Conídios aderidos nas proximidades das setas marginais do histerossoma..........

10 Germinação de Hirsutella sp. em Brevipalpus phoenicis (12 haa). A) Conídios aderidos ao tegumento apresentando formação do tubo germinativo. B) Detalhe de um conídio germinando na base de uma seta.

11 A) Crescimento micelial na região dorsal de Brevipalpus phoenicis (24 haa). B) Germinação (seta amarela) e desenvolvimento hifal (seta verde) de Hirsutella sp. na folha de citros.

12 Crescimento micelial de Hirsutella sp. após 48 e 72 horas da inoculação na região dorsal de Brevipalpus phoenicis. A) Micélio. B) Germinação de conídio e crescimento de micélio

13 Extrusão e conidiogênese de Hirsutella sp. (120 haa). A) Extrusão de hifas da parte posterior e anterior de Brevipalpus phoenicis. B) Extrusão e crescimento de hifas de Hirsutella sp. a longas distâncias do ácaro com detalhe do conidióforo.

14 Contato entre adultos vivos e cadáveres de Brevipalpus phoenicis colonizados por Hirsutella sp.

15 Proporção média ( \pm desvio padrão) de Brevipalpus phoenicis mortos após o quarto, quinto e sexto dia de contato com cadáveres de ácaros colonizados por Hirsutella sp. 


\section{LISTA DE TABELAS}

Página

1 Isolados de fungos entomopatogênicos testados para o controle de

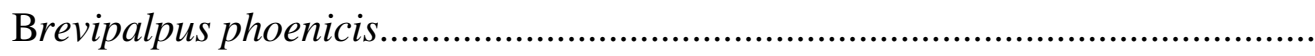

2 Mortalidade total, acumulada e corrigida de adultos de Brevipalpus phoenicis ao Terceiro e sexto dias após a inoculação com diferentes isolados de fungos entomopatogênicos

3 Mortalidade total, acumulada e corrigida de adultos Brevipalpus phoenicis, inoculados com uma suspensão de $1 \times 10^{8}$ conídios $/ \mathrm{mL}$ do isolado padrão de Beauveria bassiana (447) utilizado nos bioensaios de

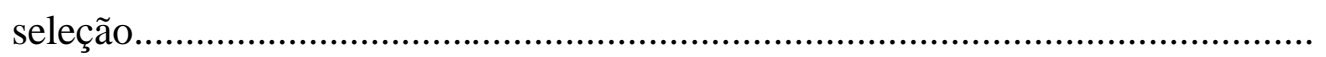

4 Análise de variância para o fator diâmetro de colônias $(\mathrm{cm})$ de quatro isolados de Hirsutella spp

5 Teste de Tuckey para médias de diâmetro de colônias $(\mathrm{cm})$ de quatro isolados de Hirsutella spp.

6 Análise de variância para o fator produção (conídios/colônias) de quatro isolados de Hirsutella spp. 
7 Teste de Tuckey para médias de produção (conídios/colônias) de quatro

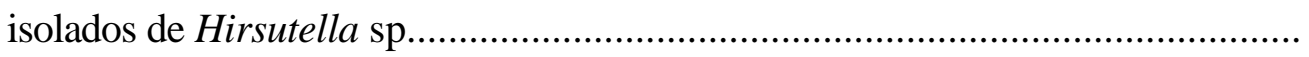

8 Mortalidade média (\%) de Brevipalpus phoenicis quando mantidos na presença de cadáveres esporulados pelo patógeno após o quatro e cinco dias........

9 Proporções médias (\%) de Brevipalpus phoenicis mortos em relação ao número de ácaros sadios misturados aos 5 cadáveres obtidas ao quarto, quinto e sexto dias após a transferência.

10 Análise de variância para o efeito de Hirsutella sp. (isolado 1269) na mortalidade de Brevipalpus phoenicis quando inoculada em folhas de citros.

11 Porcentagem de mortalidade média de Brevipalpus phoenicis quando mantidos em contato com substrato contaminado com as suspensões de Hirsutella sp. após o quarto dia da transferência 


\title{
SELEÇÃO DE FUNGOS ENTOMOPATOGÊNICOS E INFECÇÃO DE Hirsutella sp. EM Brevipalpus phoenicis (Geijskes, 1939)
}

\author{
Autor: LUCIANA SAVOI ROSSI \\ Orientador: Prof. Dr. SÉRGIO BATISTA ALVES
}

\section{RESUMO}

Avaliou-se em laboratório a patogenicidade de 52 isolados de fungos entomopatogênicos a Brevipalpus phoenicis e a produção, em meio sólido, de quatro isolados de Hirsutella spp.. Utilizando-se microscópio eletrônico de varredura, estudouse as etapas do ciclo biológico de Hirsutella sp. (isolado 1269) em adultos de $B$. phoenicis, além da ocorrência de transmissão horizontal deste patógeno para adultos do ácaro a partir de cadáveres esporulados e de substrato contaminado. Todos os isolados de Hirsutella sp. foram patogênicos para o ácaro causando mortalidade de adultos superiores a 90\% após seis dias da inoculação. Comprovou-se também que em meio de cultura completo (M.C.) que o isolado 1269 foi o que apresentou maior crescimento vegetativo e esporulação, sendo selecionado como o mais promissor. O ciclo biológico completo de Hirsutella sp., desde a adesão dos conídios ao ácaro até sua extrusão, ocorreu em 120 horas após a aplicação. A transmissão horizontal do patógeno a partir de cadáveres e do substrato contaminado ocasionou mortalidade superior a 50\% em ambas as situações, comprovando que o fungo foi capaz de infectar novos hospedeiros. Contatou-se que Hirsutella sp. é um patógeno eficiente no controle de B. phoenicis podendo ser utilizado em campo em estratégias de introdução inoculativa, inundativa, incremento e conservação. 


\title{
SELECTION OF ENTOMOPATHOGENIC FUNGI AND INFECCION OF Hirsutella sp. ON Brevipalpus phoenicis (Geijskes, 1939)
}

\author{
Author: LUCIANA SAVOI ROSSI \\ Adviser: Prof. Dr. SÉRGIO BATISTA ALVES
}

\section{SUMMARY}

In this research, the patogenicity of 52 isolates of entomopathogenic fungi against Brevipalpus phoenicis and the production of four isolates of Hirsutella spp. in solid medium (M.C.) were evalueted under laboratory condition. The stages of the biological cycle of Hirsutella sp. (isolated 1269) on adults of B. phoenicis were evalueted with the use of an electron scan microscope, besides the occurrence of horizontal transmission of this fungi from cadavers and from an inoculate substract to new hosts. The isolates of Hirsutella sp. tested were pathogenic to the mite, with high mortality (>90\%) after six days of the inoculation. The isolate 1269 showed high levels of vegetative growth and sporulation and was selected as the most promising one. The complete biological cycle of Hirsutella sp. ocurred after 120 hours of the inoculation, from adhesion to extrusion processes. The horizontal transmission of fungi from cadavers and inoculate substract ocurred by causing levels mortality superior to $50 \%$ in both cases, showing that the fungi was capable to infect new hosts in these situations. Hirsutella sp. was an efficient pathogen in the control of B. phoenicis and could be exploited in field control strategies through an inoculative introduction, increment or conservation. 


\section{INTRODUÇÃO}

No agroecossistema cítrico ocorrem diversas espécies de pragas que são responsáveis por perdas significativas na produção devido aos danos diretos e indiretos que ocasionam. Dentre todas as pragas consideradas chave na cultura dos citros, o ácaroda-leprose Brevipalpus phoenicis (Geijskes, 1939) é uma das mais importantes. Esse ácaro é vetor do vírus da leprose-dos-citros, doença que afeta ramos, folhas e frutos, ocasionando prejuízos à produção.

O controle desta doença é feito por meio da redução da população dos ácaros, basicamente pela utilização de acaricidas químicos que, quando aplicados de forma inadequada, podem favorecer o desenvolvimento de resistência do vetor ao produto, além de ocasionar desequilíbrios no agroecossitema.

Assim, medidas de controle biológico são alternativas para reduzir a população desta praga abaixo do nível de dano econômico, sem riscos de contaminação do ambiente. Dentre estas, destaca-se o controle microbiano pela utilização de microrganismos entomopatogênicos. O emprego do controle microbiano, além de reduzir a população do ácaro e número de plantas doentes, minimiza o problema do desenvolvimento de resistência do vetor aos agrotóxicos utilizados na cultura.

Assim, utilizando uma estratégia adequada que considera aspectos da cultura, da praga e do patógeno empregado, o controle microbiano de B. phoenicis representa uma alternativa viável e segura para a manutenção do equilíbrio no agroecossitema cítrico, além de minimizar os prejuízos ocasionados por este ácaro. 


\section{REVISÃO DE LITERATURA}

\subsection{Distribuição geográfica e plantas hospedeiras de Brevipalpus spp.}

Os ácaros fitófagos que apresentam importância econômica, estão distribuídos em duas superfamílias, a Tetranychoidea, da qual destacam-se as famílias Tetranychidae e Tenuipalpidae, e Eriophyoidea, que congrega a família Eriophyidae e reúne os gêneros com as espécies mais importantes (Chiavegato, 1979).

Vivendo em locais de clima tropical e subtropical, os representantes da família Tenuipalpidae, comumente denominados "ácaros planos" devido ao aspecto achatado da maioria das espécies, alimentam-se das plantas hospedeiras utilizando-se de um par de dígitos estiliformes da quelícera. O padrão reticulado do idiossoma, os tipos e disposição dos pêlos pelo corpo são caracteres importantes na identificação das espécies pertencentes a esta família (Jeppson et al., 1975).

O gênero mais importante é Brevipalpus, o qual é separado em dois grandes grupos de acordo com o número de setas marginais presentes no histerossoma e o número de setas sensoriais na parte distal do tarso (Yaninek \& Moraes, 1991). Existem diversas espécies descritas pertencentes a este gênero e somente em citros já foram identificadas dez espécies de Brevipalpus, incluindo Brevipalpus californicus (Banks), Brevipalus chilensis Baker, Brevipalpus karachiensis Chaudhri, Akbar \& Rasool, Brevipalpus lewisi (McGregor), Brevipalpus mcgregori Baker, Brevipalpus obovatus Donnadieu, B. phoenicis (Geijskes), Brevipalpus rugulosus Chaudhri, Akbar e Rasool e Breviplapus tinsukiaensis Sadena \& Gupta (Baker \& Suigong, 1988 citados por Childers et al., 2001a). No Brasil, a espécie de maior ocorrência é B. phoenicis que caracteriza-se por possuir apenas cinco pares de setas marginais no histerossoma (Gonzáles, 1975).

B. phoenicis é cosmopolita e polífago, ou seja, seus danos podem ser observados em diversas plantas hospedeiras como chá, algodão, maracujá, café, frutas de climas 
temperado e tropical, além de plantas ornamentais (Meyer, 1981; Young et al., 1995; Kitajima et al., 1997; Reis et al., 2000). Apesar deste ácaro ocorrer em mais de 83 gêneros de plantas no mundo, o de maior destaque é Citrus spp. devido aos sérios prejuízos que ocasiona à produção desta cultura (Flechtmann, 1977; Chiavegato \& Mischan, 1987).

Na América Central, há registros de um total de 177 hospedeiros para $B$. phoenicis, B. californicus e B. obovatus, abrangendo 114 hospedeiros para B. phoencis, 29 para B. californicus e 34 para B. obovatus (Ochoa et al., 1994). No Brasil já foram relatados trinta e sete hospedeiros destas três espécies de ácaros, especialmente fruteiras e café (Reis, 1974). Estudos conduzidos por Trindade \& Chiavegato (1994) comprovaram a existência 34 espécies de plantas hospedeiras de B. phoenicis, oito de $B$. obovatus e três de B. californicus em algumas localidades do Estado de São Paulo, evidenciando a maior ocorrência da primeira espécie.

\subsection{Bioecologia de $B$. phoenicis}

A reprodução de $B$. phoenicis é predominantemente partenogenética telítoca do tipo automítica, ou seja, fêmeas dão origem a fêmeas haplóides com dois cromossomos. Nesta espécie, a haploidia em fêmeas partenogenéticas é ocasionada por uma bactéria endosimbiótica do gênero Wolbachia a qual induz a "feminização" de machos por processos desconhecidos. $\mathrm{Na}$ ausência deste microrganismo, fêmeas adultas também podem, eventualmente, dar origem a machos haplóides (Helle et al., 1980; Weeks et al., 2001). Em populações naturais, ambos os sexos desta espécie são encontrados sendo os machos relativamente raros (Flechtmann, 1977; Pijnacker et al., 1980).

O ciclo biológico típico de Brevipalpus spp. envolve as fases de ovo, larva, protocrisálida, protoninfa, deutocrisálida, deutoninfa, teliocrisálida e adulto. Destas fases, quatro são ditas ativas (larva, protoninfa, deutoninfa e adulto) e quatro imóveis mas fisiologicamente ativas (protocrisálida, protoninfa, deutocrisálida e teliocrisálida) (Childers et al., 2001a). 
A taxa de desenvolvimento e tempo de duração de cada fase e de todo o ciclo de $B$. phoenicis são muito variáveis em função da temperatura, umidade relativa e especialmente, da planta hospedeira (Haramoto, 1969; Lal, 1978; Helle et al., 1980; Trindade \& Chiavegato, 1994). Para citros, o ciclo do ácaro em frutos de laranja "Pêra Rio" variou de 14,37 a 43,46 dias em temperaturas de $30^{\circ} \mathrm{C}$ e $20^{\circ} \mathrm{C}$ e umidade relativade $60 \%$, respectivamente . Quando comparados aos frutos, as folhas de citros constituiramse piores substratos com menor número de descendentes/fêmea e maior tempo de desenvolvimento $\left(17,62\right.$ dias a $30^{\circ} \mathrm{C}$ e $60 \%$ de umidade relativa) (Chivegato, 1986).

Após o período de pré-oviposição, a fêmea deposita os ovos nas folhas ou frutos, normalmente em locais abrigados, como fendas, lesões, escamas de cochonilhas, envolvidos nas próprias exúvias ou grânulos de poeira (Chiavegato, 1986). Assim, em estudos que compararam a preferência do ácaro dentre diversas partes da planta de citros comprovou-se que as maiores infestações ocorrem em frutos com sintomas de verrugose e menores em frutos sem estas características, além de ramos e folhas (Martinelli et d., 1976; Chiavegato \& Kharfan, 1993; Childers et al., 2001a).

Em pomares cítricos do Estado de São Paulo, B. phoenicis ocorre praticamente o ano todo, com picos populacionais em épocas de menor precipitação pluviométrica que correspondem ao período de julho a outubro (Oliveira, 1986). Outro fator que exerce grande influência no desenvolvimento da população do ácaro, além da umidade relativa e taxa de precipitação, é a temperatura do ar (Chiaradia et al., 2000). Semelhante ao observado em pomares paulistas, estes autores observaram que no município de Chapecó (SC), os níveis populacionais de B. phoenicis em pomar de "Valência" mantiveram-se elevados durante todo o período de estudo (julho de 1997 a agosto de 1998), com picos entre os meses de setembro e dezembro.

\subsection{Importância e danos associados a B. phoenicis}

B. phoenicis é considerado uma das pragas-chave da cultura de citros no Brasil, devido à sua capacidade de transmissão do vírus da leprose, um rabdovírus de ação localizada que ataca ramos folhas e frutos (Gonzáles, 1975; Chiavegato, 1979; Oomen, 
1982). Na América, esta doença foi constatada pela primeira vez em 1962 em pomares da Flórida (EUA) e, atualmente, há descrições de sua ocorrência em países como Argentina, Paraguai, Venezuela, Colômbia, Uruguai e Panamá (Rodrigues, 2000; Domingues et al., 2001; Childers et al., 2001b). Outras espécies de Brevipalpus também estão associadas a disseminação do vírus da leprose em citros como $B$. obovatus e $B$. californicus no sul dos Estados Unidos (Flórida e California), Argentina, Costa Rica, Honduras e África do Sul (Musumeci \& Rossetti, 1963; Knorr et al., 1968; Evans et al., 1993; Ochoa et al., 1994).

Após seu desaparecimento na Flórida, a leprose está praticamente restrita a América do Sul, o que levou os EUA a imporem limitações severas de importação de frutas provenientes de países desta região (Childers et al., 2001b). No Brasil, levantamentos efetuados em pomares cítricos das regiões norte, sul, noroeste e centro do Estado de São Paulo realizados pelo Fundo Paulista de Defesa da Citricultura (Fundecitrus) em 1995, mostraram que em mais de $60 \%$ dos pomares vistoriados apresentam aproximadamente $26 \%$ de plantas com sintomas de leprose (Rossetti et al., 2002).

Os sintomas desta doença são caracterizados por manchas cloróticas nas folhas, ramos e frutos, queda acentuada e diminuição no peso dos frutos e até a morte da planta quando o ataque é severo. Desta forma, a qualidade e a quantidade de frutos são afetados e a planta pode tornar-se improdutiva dependendo da intensidade do ataque da praga (Guinado \& Silvério, 1992; Rodrigues et al., 1994; Oliveira, 1994; Salva \& Massari, 1995). Nas folhas, as manchas cloróticas, muitas vezes, acompanham o sentido das nervuras, apresentando um formato alongado e tornando-se necrosadas (Chiavegato et al., 1982; Childers, 1994; Reis et al., 2000).

A intensidade dos sintomas nas folhas, brotos verdes e frutos pode variar em função da variedade da planta hospedeira e estágio de infecção pelo vírus. As variedades de "laranja doce" (Citrus sinensis) são consideradas as mais suscetíveis (Childers et al., 2001a) ao passo que, a baixa incidência de sintomas de leprose na variedade "Murcote" indica a resistência ou tolerância desta variedade ao agente causal (Oliveira, 1986). 
As primeiras observações e especulações a respeito da relação entre o desenvolvimento da doença e a presença do ácaro foram realizadas por pesquisadores na Argentina e, posteriormente, confirmadas no Brasil e Estados Unidos (Musumecci \& Rossetti, 1963; Knorr, 1968). Devido ao desconhecimento do agente etiológico, inicialmente duas hipóteses foram sugeridas para explicar o aparecimento dos sintomas de leprose nas plantas: produção e introdução de uma toxina na planta pelo ácaro durante sua alimentação; inoculação de uma partícula de vírus transmitida pelo vetor (Rodrigues et al., 1997).

A análise de secções ultrafinas de tecidos de B. phoenicis em microscópio eletrônico revelou a ocorrência de partículas de vírus similares aos vírus fitopatogênicos dos grupos Badnavirus e Rhabdovirus (Kitajima et al., 1971). Observações em células do tecido foliar de citros com sintomas de leprose foram realizadas e detectou-se a presença de partículas tipo "bastonetes", semelhantes a vírus, de 40-50 nm x 100-110 nm no núcleo e no citoplasma (Kitajima, 1972), confirmando a etiologia viral da doença. Tais partículas, porém, não foram verificadas em folhas infectadas sem sintomas e também em áreas onde o tecido foliar apresentava-se normal.

Estudos recentes e observações no núcleo e membranas do retículo endoplasmático indicaram que existem dois tipos de vírus da leprose, o "nuclear" e o “citoplasmático", ambos comprovadamente transmitidos por Brevipalpus spp.. Apesar de provocarem alterações em locais distintos da célula e apresentarem aspectos morfológicos diferentes, os sintomas da doença são muito semelhantes para ambos, sendo o tipo citoplasmático o mais comum (Kitajima et al., 1997; Childers et al., 2001).

A natureza viral da leprose foi comprovada por meio da inoculação mecânica do agente causal e constatação do aparecimento de sintomas similares aos da doença em diferentes variedades de citros e outras hospedeiras (Colaricio et al.,1995). Nestes estudos, as partículas virais não foram encontradas em áreas adjacentes ao tecido contaminado, indicando a característica não-sistêmica do vírus. A transmissão por meio da implantação de tecido foliar infectado de citros em tecido caulinar verde e sadio também foi comprovada, embora nesta situação o índice de transmissibilidade tenha sido baixo (Knorr et al., 1968; Chagas \& Rossetti, 1980). Estes aspectos ressaltam a 
importância do vetor $B$. phoenicis na epidemiologia, porque a presença do ácaro é condição essencial, sem a qual não ocorre a disseminação da leprose (Rodrigues et al., 1997). Além de citros, há relatos da ocorrência de doenças associadas a B. phoenicis como a "clorose zonada", "mancha anular do cafeeiro", "mancha anular do ligustro" (Ligustrum lucidum) "pinta verde" no maracujazeiro e "rind spotting" em uva, cujos sintomas são semelhantes aos da leprose em citros (Musumeci \& Rossetti, 1963; Rossetti et al., 1965; Chagas, 1973; Reis et al., 2000;Childers, 1994; Kitajima et al., 1997).

A aquisição do vírus pelos ácaros ocorre por meio da alimentação em substratos contaminados e todos os estágios de desenvolvimento de B. phoenicis que se alimentam são capazes de transmití-lo para a planta hospedeira (Chiavegato, 1995). As larvas são capazes de transmitir o vírus após 24 da aquisição, mais rapidamente em comparação à ninfas e adultos (Chiavegato \& Salibe, 1984 citados por Childers, 1994). Apesar da hipótese da transmissão transovariana entre progênies de B. obovatus e B. californicus, para B. phoenicis apenas a transmissão transestadial foi comprovada (Boaretto et al., 1993; Rodrigues et al., 1997). Assim, uma vez que as larvas adquirem o vírus, são capazes de transmití-lo durante todos os estágios de desenvolvimento subseqüentes e durante a fase adulta, agravando o problema devido ao longo ciclo de vida desta espécie.

\subsection{Controle químico de B. phoenicis em citros}

Para evitar o aparecimento dos sintomas da leprose e perdas na produção devido a doença, é necessário o controle do vetor $B$. phoenicis. De acordo com Rossetti et al. (2002), medidas de manejo do pomar como plantio de mudas sadias, poda de limpeza, controle de plantas daninhas que servem como hospedeiros alternativos, colheita antecipada dos frutos, inspeções regulares, limpeza dos equipamentos e controle químico podem colaborar para diminuição de infestações desta e de outras pragas que ocorrem em citros.

A utilização de acaricidas é a tática mais difundida no controle deste ácaro. Somente no ano de 1999 estimou-se que os gastos efetuados para o controle de $B$. 
phoenicis tenham sido de US\$ 75 milhões apenas no Estado de São Paulo (FNP, 2000). Segundo Omoto (1998), os gastos com o controle de B. phoenicis representam cerca de $21 \%$ dos custos totais da produção de citros no Brasil.

No mercado encontram-se diversos produtos para o manejo do ácaro da leprose e dentre estes pode-se citar os grupos dos organoestânicos (cyhexatin, óxido de fenbutatin, azociclotin), piretróides (bifentrina, fenpropatrina), carboxamides (hexythiazox), organoclorados (dicofol), phenoxipirazoles (fenpyroximate), oxithioquinoxes (quinometionato), norpirétricos éster (acrinathrin) e sulfites éster (propargite) (Rossetti et al. 2002).

Dos trabalhos publicados que avaliam o potencial do controle químico para o ácaro da leprose, a maioria testa a eficiência dos produtos em situações de campo (Veloso et al., 1988; Arashiro et al., 1988; Mariconi et al., 1989; Raga et al., 1990; Chiavegato et al., 1993; Chiavegato et al., 1994; Moraes et al., 1995; Oliveira et al., 1998).

Além da utilização de acaricidas para controle de B. phoenicis, há a ocorrência no pomar cítrico de outro ácaro considerado de grande importância devido aos prejuízos que ocasiona à produção: Phyllocoptruta oleivora, ou ácaro da falsa-ferrugem-dos-citros (Flechtmann, 1977; Gravena, 1990; Oliveira, 1994; Gravena, 1998). Apesar dessas espécies ocorrerem praticamente o ano todo, o período crítico de infestação de cada uma é diferente sendo que $P$. oleivora é maior problema durante o verão quando a população de B. phoenicis é relativamente baixa. Assim, no Brasil, a freqüência de aplicação de produtos em citros é grande e realizada, em média, duas a quatro vezes ao ano somente para estas pragas, sendo considerada entre as frutíferas, a que uitliza mais defensivos químicos (Omoto, 1998; Rossetti et al., 2002).

Nos últimos anos, falhas no controle do ácaro da leprose vêm sendo observadas. Uma das causas já comprovadas em estudos de laboratório e em campo é o desenvolvimento de resistência de B. phoenicis devido à intensidade do uso de muitos acaricidas (Omoto, 1998). Este problema vem se agravando principalmente devido à bioecologia da praga, táticas de controle mal empregadas e genética da resistência que são os principais fatores envolvidos com o desenvolvimento acelerado deste processo 
mediante grande pressão de seleção (Georghiou \& Taylor, 1977). Para alguns dos acaricidas mais utilizados como o Dicofol e o Hexythiazox já foi detectada e caracterizada resistência desta praga (Alves et al., 1998; Alves, 1999, Alves et al., 2001).

\subsection{Controle microbiano de ácaros em citros}

Uma das principais estratégias de manejo estudadas e utilizadas para minimizar o problema da resistência de B. phoenicis são os agentes de controle biológico. Estes agentes, representados por predadores, parasitóides e patógenos, são de grande importância no controle natural das pragas em culturas perenes, podendo ser introduzidos em áreas que não ocorram, incrementados ou protegidos em locais que já estejam presentes (Costa Junior. \& Lopes, 2000). Neste trabalho serão abordados apenas os agentes microbianos de controle.

Doenças que ocorrem em populações de ácaros têm recebido pouca atenção, devido, especialmente, à dificuldade da identificação dos sintomas em organismos de tamanho tão reduzido. Apesar do grande número de espécies de ácaros identificadas e sua importância agrícola e médico-veterinária, a maioria das pesquisas na área de

patologia de ácaros concentram-se, especialmente, em patógenos de eriofiídeos e tetraniquídeos (Van der Geest et al., 2000).

Dentre os diversos agentes de controle microbiano, Alves (1998) destaca os fungos e vírus entomopatogênicos como os principais patógenos que apresentam potencial para redução da população de ácaros fitófagos, como já foi constatado para as espécies Panonychus citri e P. oleivora que ocorrem em citros (Spears \& Yothers, 1924; Bearvers \& Reed, 1972).

\subsubsection{Vírus entomopatogênicos}

Os trabalhos referentes à ocorrência de doenças virais em ácaros de citros retringem-se à espécie $P$. citri conhecida como ácaro purpúreo dos citros. 
A primeira descrição de vírus não-inclusos atacando esta praga foi feita por Muma em 1955 em pomares cítricos da Flórida (EUA), o qual constatou a ocorrência de ácaros com sintomas de diarréia. Os ácaros mortos apresentavam o corpo flácido e uma substância negra e resinosa no ânus que permitia que ficassem colados na superfície da folha. Posteriormente, a presença desta mesma espécie, com sintomas semelhantes, foi verificada em pomares da Califórnia (EUA). Nestes ácaros foi constatada a presença de partículas de 35 mu de diâmetro semelhantes a vírus (Smith et al., 1959).

A comprovação da etiologia da doença somente foi realizada por Reed \& Hall (1972), os quais verificaram no núcleo de células epiteliais do intestino médio dos ácaros a presença de partículas em forma de bastonete, inclusas em um envelope.

Os sintomas e sinais da doença viral em $P$. citri são complexos e bem característicos. Além da ocorrência de diarréia, é bastante evidente a completa imobilização dos ácaros após a morte, enrrijecimento das pernas e fixação no substrato devido a substância exudada do ânus. No hemocele é possível observar em alguns exemplares, numerosos cristais birefringentes, de formato irregular, os quais são resultado de distúrbios metabólicos (Lipa, 1971).

Estudos conduzidos em laboratório comprovaram que $P$. citri infectados por vírus podem levar de 7 a 18 dias para manifestar os primeiros sintomas da doença, dependendo do potencial de inóculo do patógeno e do estágio de desenvolvimento do ácaro (Munger et al., 1959). Este trabalho também demonstrou que todos os estágios de desenvolvimento de P. citri são suscetíveis, exceto o ovo. Gilmore \& Tashiro (1966), avaliaram parâmetros como fecundidade, longevidade e transinfectividade de $P$. citri infectados por vírus não-inclusos e concluíram que a redução na longevidade e fecundidade das fêmeas adultas é mais intensa quando estas adquirem o vírus em algum estágio da fase imatura. A taxa de mortalidade das fêmeas adultas recém-emergidas foi de $40 \%$ após 6 dias da inoculação e 100\% após 9 dias.

A transmissão do vírus entre os ácaros foi verificada inicialmente por Munger et al. (1959). Neste estudo, tanto na aplicação de uma suspensão aquosa preparada a partir de ácaros doentes sobre ácaros sadios, quanto na transferência de ácaros sadios para colônias de ácaros infectados foi possível verificar a transmissão horizontal do vírus. O 
período ótimo em que ocorre maior transmissão do patógeno é entre o terceiro e quarto dias da inoculação, continuando após a morte do ácaro (Gilmore \& Tashiro ,1966). Em condições naturais, os "vírions" liberados do ânus, boca, ou aberturas do aparelho reprodutivo mantém-se nos substratos e são ingeridos pelos ácaros sadios em consequência da alimentação (Poinar Júnior \& Poinar, 1998). De acordo com Lipa (1971), não foi identificada transmissão transovariana de vírus não-inclusos para as progênies de $P$. citri.

A ocorrência natural de epizootias ocasionadas por vírus em populações de $P$. citri vem sendo descrita a partir de meados da década de 50 nas principais zonas citrícolas dos EUA (Munger et al., 1959; Tashiro \& Beavers, 1966; Shaw et al., 1968).

Estudos de epizotiologia conduzidos por Shaw et al. (1968), foram realizados no centro da Califórnia e comprovaram que dos cinqüenta e um pomares amostrados durante o período de fevereiro de 1966 a maio de 1967, em 68,6\% foram coletados ácaros infectados. Os níveis de infecção permaneceram relativamente baixos até que a população do ácaro aumentasse quando então ocorriam os picos da epizootia. Nenhum fator ambiental ou relacionado à práticas culturais favoreceu a doença, que se manteve em níveis enzoóticos durante a maior parte do ano.

Observações semelhantes feitas em Corona (Califórnia) por Tashiro \& Beavers (1966) revelaram que o maior índice de ácaros doentes ocorria quando a sua população estava muito alta, concluindo que em determinados períodos do ano a doença tem papel muito importante na supressão populacional de $P$. citri.

Assim, devido à distribuição da doença, às drásticas reduções das populações de $P$. citri em alguns períodos do ano e a capacidade de transmissão do patógeno em condições naturais, muitos trabalhos foram conduzidos para o desenvolvimento de um produto microbiano que pudesse ser utilizado no controle do ácaro em campo.

No Brasil, ainda não existem relatos da ocorrência desta doença em populações de $P$. citri. As primeiras tentavas de utilizar vírus visando o controle de infestações de $P$. citri em campo foram estudadas por Gilmore (1965). Durante um período de dois anos, foram realizadas liberações de ácaros doentes, além de aplicações consecutivas de suspensões aquosas contendo vírus em pomares cítricos infestados por P. citri. Nesta 
ocasião, não foi possível verificar efetivamente o desempenho das liberações devido às constantes epizootias naturais que ocorriam na área. Posteriormente, Shaw et al. (1968b) realizaram aplicações da suspensão aquosa produzida a partir de um macerado de ácaros doentes, não observando diferenças nos tratamentos realizados.

Apesar dos resultados obtidos nos trabalhos conduzidos em campo, as aplicações de vírus em grande escala nunca foram realizadas devidos a alguns entraves. Além de comprovações do efeito negativo que altas temperaturas e radiação solar promovem nas partículas virais, os custos de produção da suspensão aquosa os quais envolviam a criação massal do ácaro associada ànecessidade de sua coleta em campo, eram muitos altos (Poinar Júnior \& Poinar, 1998; Van der Gesst et al., 2000).

\subsubsection{Fungos entomopatogênicos}

De acordo com Alves (1998), os fungos são patógenos mais freqüentemente encontrados em populações de ácaros, contribuindo para seu controle em diferentes culturas. Os estudos para a utilização destes patógenos em ácaros que ocorrem em citros concentram-se em Hirsutella thompsonii, Verticillium lecanii e a várias espécies pertencentes à ordem Entomophthorales.

\subsubsection{Ordem Entomophthorales}

As espécies de fungos pertencentes a ordem Entomophthorales são importantes patógenos de ácaros de maneira geral (Lipa, 1971). Apesar da taxonomia deste grupo ser confusa e passar constantemente por revisões, os principais gêneros que atacam ácaros descritos são Entomophthora e Neozygites (Lipa, 1971; Van der Geest et al., 2000).

A maioria dos representantes de Entomophthorales são parasitas obrigatórios, o que significa que parasitam apenas em indivíduos vivos e sua reprodução e morte do hospedeiro ocorrem quando todos os nutrientes são esgotados (Hajek, 1997 citado por Van der Geest et al., 2000). 
A primeira observação de Entomophthorales infectando ácaros foi a ocorrência de uma espécie de Neozygites atacando P. citri em pomares cítricos da Flórida. Nesta situação, observou-se que este patógeno ocasionava índices de mortalidade variando de 32 a 95\% durante o fim do verão e começo do outono. Os ácaros mortos pelo fungo apresentavam o corpo distendido, sem consistência, com uma coloração avermelhada e com aspecto "mumificado" (Fisher, 1951; Poinar Júnior. \& Poinar, 1998).

Posteriormente, Weiser \& Muma (1966) identificaram e caracterizaram aspectos morfológicos de $N$. floridana como um importante inimigo natural de Eotetranychus banksi, ou "texas-citros-mite". Apesar desta espécie ser capaz de infectar todos os estágios de desenvolvimento do ácaro, com exceção dos ovos, as fêmeas adultas apresentaram índice de infecção de 49,2\%, enquanto que para protoninfas e deutoninfas estes valores foram de 16,5\% e 20,2\%, respectivamente (Selhime \& Muma, 1966).

$\mathrm{O}$ ciclo das relações patógeno-hospedeiro de $N$. floridana em E. banksi foi descrito por Selhime \& Muma (1966). A duração do ciclo do fungo neste hospedeiro varia de cinco a seis dias. Este inicia-se com a adesão e penetração dos conídios, terminando com a extrusão do patógeno e produção de conídios infectivos. Após a penetração, o fungo se desenvolve por todo o interior do corpo do ácaro ocasionando sua morte e rompendo o tegumento para a produção de conidióforos. Estas estruturas produzem conídios primários que são ejetados a grandes distâncias do ácaro em condições adequadas de umidade relativa. A partir dos conídios primários ocorre a produção de conídios secundários que são os propágulos infectivos deste grupo de fungos (Van der Geest et al., 2000).

As epizootias de Entomophthorales estão diretamente associadas às condições ambientais, especialmente a períodos de mudanças bruscas de temperatura com aumento da umidade relativa (Lipa, 1971; Smitley et al., 1986; Alves, 1998; Poinar Júnior \& Poinar, 1998; Van der Geest et al., 2000). Níveis de umidade relativa próximos a 100\% e temperaturas na faixa de 16 a $27^{\circ} \mathrm{C}$ são condições essenciais para que estes patógenos promovam o desenvolvimento de doenças em hospedeiros (Alves, 1998).

Para a maioria dos trabalhos verificados, os picos epizoóticos da doença ocorrem durante o outono ou final do verão, normalmente precedidos de uma chuva (Wilding, 
1981; Selhime \& Muma, 1966; Van der Geest et al., 2000). Segundo com Muma (1969) citado por Lipa (1971) epizootias naturais de N. floridana em E. banksi ocasionaram níveis de mortalidade que variaram entre $36,8 \%$ a $86,3 \%$ das amostras avaliadas em seis diferentes pomares cítricos, durante um período de quatro anos de observações constantes.

\subsubsection{Hirsutella thompsonii}

O gênero Hirsutella é um dos mais importantes patógenos que ocorrem em populações de ácaros, especialmente eriofiídeos (Lipa, 1971; McCoy, 1996; Alves, 1998; Poinar Júnior \& Poinar, 1998; Van der Geest et al., 2000).

Segundo Van der Geest et al. (2000), já foram descritas nove espécies de Hirsutella infectando ácaros, com destaque para a espécie $H$. thompsonii que é a mais estudada.

A primeira constatação de Hirsutella sp. ocorrendo em citros foi realizada na Flórida em 1924 em populações de P. oleivora (Spears \& Yothers, 1924). Estes autores observaram que em determinados períodos do ano, quando cada fruto apresentava em média 5.000 ácaros, ocorria uma queda repentina na densidade populacional reduzindo seus níveis a próximos de zero. Nesta ocasião, foram observados sobre o corpo dos ácaros mortos estruturas do patógeno. Apesar da descrição ter sido realizada em 1924, já em 1912 o desaparecimento repentino de P. oleivora dos pomares nas estações chuvosas havia sido notificado. Somente em 1950, Fisher identificou o fungo como $H$. thompsonii (Van der Geest et al., 2000).

Os sintomas típicos de $P$. oleivora infectados por $H$. thompsonii caracterizam-se pela lentidão dos movimentos dos ácaro além da mudança na coloração que passa de amarelo-pálida a amarelo-bronzeado (Lipa, 1971). Observações em campo constataram que ácaros infectados por este fungo podem apresentar um comportamento característico, o qual migram para áreas com incidência direta de luz solar, diferentemente de indivíduos sadios que procuram se abrigar em locais sombreados (Spears \& Yothers, 1924). 
Segundo Van der Geest et al. (2000), uma vez os conídios de Hirsutella sp. aderidos ao corpo do ácaro a penetração do fungo ocorre normalmente pelas pernas apesar de poder romper o tegumento em outras partes do corpo. Após a penetração, o patógeno se desenvolve e produz micélio que se ramifica dentro do hospedeiro. Estas estruturas podem, em certas condições, formar clamidósporos multinucleados os quais germinam e produzem um micélio que se reproduz assexuadamente no substrato foliar (McCoy, 1988). A extrusão do patógeno é normalmente pelas aberturas genital, anal, boca ou apêndices, ocorrendo o desenvolvimento externo de hifas e produção dos conídios formados isoladamente nos conidióforos. A distância a que se desenvolvem as hifas e projetam-se os conidióforos a partir do corpo do hospedeiro depende do tamanho do mesmo (Sosa-Gómes \& Nasca, 1983; McCoy, 1996).

Trabalhos recentes identificaram e avaliaram a atividade metabólica de algumas toxinas produzidas por diferentes isolados de Hirsutella sp. (Vey et al., 1993; Liu et al., 1996; Omoto \& McCoy, 1998). Testes realizados em larvas de Galleria mellonella, adultos de Drosophila melanogaster e Bombyx mori revelaram altos níveis de mortalidade além dos efeitos citotóxicos de uma proteína extraída de $H$. thompsonii em várias partes do corpo dos insetos (Vey et al., 1993). Após a comprovação de seus efeitos deletérios à células de invertebrados, este peptídeo foi denominado Hirsutellin A (Liu et al., 1996). O efeito de contato e residual de Hirsutellin A na sobrevivência e taxa de oviposição de $P$. oleivora indicaram que há diminuição no número de ovos produzidos por fêmea e que altos níveis de mortalidade são atingidos quando se aumenta a concentração da toxina (Omoto \& McCoy, 1998). Segundo estes últimos autores, são necessárias pesquisas que revelem a relação entre os efeitos das toxinas e o crescimento vegetativo do patógeno dentro do hospedeiro, e sua atuação simultânea na mortalidade do ácaro.

Além da verificação de epizootias naturais em populações de $P$. oleivora, outras espécies de ácaros estão sujeitas a infecções por Hirsutella sp. Em pomares cítricos da região central da Flórida foi identificada $H$. tydeicola atacando Tydeus gloveri. Coletas destes ácaros em campo revelaram índices de infecção de 40 a 100\% (Samson \& McCoy, 1982). Além de P. oleivora, a ocorrência natural de H. thompsonii também foi 
verificada em P. citri, B. phoenicis, Polyphagotarsonemus latus e Eriophyes sheldoni em alguns locais dos EUA e América Central (Muma, 1955; Zoebisch et al., 1992; Alves, 1998). No Brasil, a ocorrência natural de $H$. thompsonii em P. oleivora foi relatada para pomares cítricos do Estado de São Paulo (Alves, 1986; Correia et al., 1992; Alves, 1998).

Devido à sua importância e capacidade de reduzir drasticamente a população de $P$. oleivora em sua época de maior infestação, foi desenvolvido na década de 70 um micoacaricida $\left(\right.$ Mycar $^{\circledR}$ ) obtido de fermentação bifásica a base de H. thompsonii (strain Fla CBS 556.77b) (McCoy \& Couch, 1978; McCoy \& Couch, 1982; McCoy, 1996). Este produto, comercializado pela Abbott Laboratories até 1985 nas formulações pó seco e pó molhável, foi registrado e utilizado com bons resultados como produto microbiano para controle de ácaros em citros (Van der Geest et al., 2000).

Em campo, a estratégia chave de sucesso para a utilização deste produto foi a aplicação do produto em épocas adequadas que permitissem ao patógeno um estabelecimento de suas estruturas infectivas na área até o aumento da população do ácaro (McCoy, 1996). Testes em campo indicaram redução na população de $P$. oleivora a praticamente zero após quatro semanas da aplicação de 4 e 6 lbs/100 gal. Nesta mesma ocasião, na área em que não foi realizada aplicação do patógeno, observou-se uma média de 30\% de cadáveres esporulados pelo fungo (McCoy \& Couch, 1982).

Em 1985, apesar da utilização do Mycar $^{\circledR}$, sua produção e comercialização foi encerrada. Isto ocorreu, especialmente, devido a problemas relacionados a formulação que afetaram a estabilidade das estruturas infectivas do patógeno durante a estocagem, transporte, além da baixa aceitação de muitos centros citrícolas a um produto diferenciado e com particularidades no modo de ação (Alves, 1986; McCoy, 1996; Van der Geest et al., 2000).

De acordo com Van der Geest et al. (2000), mesmo após a retirada de Mycar ${ }^{\circledR}$ do mercado, países como o Brasil e Argentina continuaram realizando pesquisas com diferentes isolados de $H$. thompsonii para sua utilização prática no controle de ácaros fitófagos. Em um estudo realizado no México em pomar de Citrus aurantifolia avaliou- 
se a flutuação populacional de $B$. phoenicis e B. obovatus mediante a aplicação com suspensões de micélio de $H$. thompsonii $(50 \mathrm{~g} / \mathrm{L})$, malation $(3 \mathrm{ml} / \mathrm{L})$ e diazinon $(3 \mathrm{ml} / \mathrm{L})$ além da testemunha (água). $\mathrm{O}$ tratamento com fungo mostrou-se o mais eficiente, promovendo maior diminuição na taxa populacional e conseqüente redução dos danos de Brevipalpus spp em frutos e folhas. Depois de três aplicações, o patógeno ainda persistiu nas plantas tratadas por até seis meses, demonstrando possibilidade de estabelecimento na área (Acevedo \& Rosas, 2000).

A eficiência de Hirsutella sp. em campo está diretamente relacionada a fatores como alta virulência dos isolados sobre a praga-alvo, condições ambientais favoráveis e estratégia de controle empregada (McCoy \& Lye, 1995; McCoy, 1996; Van der Geest et al., 2000; Alves et al., 2000). Estes fatores, associados a seletividade a outros inimigos naturais, compatibilidade a produtos químicos e baixa periculosidade ao homem e outros animais também são aspectos que devem ser considerados para sua utilização prática.

Com relação ao impacto de Hirsutella sp. em outros organismos benéficos, alguns estudos tem sido realizados. Para os coccinelídeos Coccidophilus citricola e Lindorus lophantae, dois importantes agentes de controle biológico em pomares cítricos da Argentina, não foi observada patogenicidade de H. thompsonii (Sosa Gomez et al., 1985). Entretanto, para Amblyseius peregrinus (Phytoseiidae) e Trachyuropoda coccinea (Trachyuropodidae), este patógeno mostrou-se pouco seletivo (McCoy, 1981; Balazy \& Wisniewski, 1982 citados por Van der Geest et al., 2000). Com relação a mamíferos, formulações de micélio de $H$. thompsonii não apresentaram efeitos nocivos a estes organismos não-alvo (McCoy, 1996).

Os fatores ambientais mais influentes no desenvolvimento de $H$. thompsonii são temperatura e umidade relativa. De acordo com Keneth et al. (1979), a temperatura ideal para o desenvolvimento deste patógeno é de 25 a $30^{\circ} \mathrm{C}$, afetando especialmente os processos de germinação e conidiogênese quando a variação é muito superior ou inferior a estes limites. As epizootias naturais de Hirsutella sp. ocorrem quando há interação entre temperatura, umidade e patógeno, além da presença do hospedeiro-alvo (Poinar Júnior. \& Poinar, 1998). 


\subsubsection{Outros Hyphomycetes}

Apesar da grande importância da ordem Entomophthorales e de Hirsutella spp., outras espécies de fungos da classe dos Hyphomycetes tem sido descritos como patógenos de ácaros que ocorrem em citros.

De acordo com Peña et al. (1996), além de H. thompsonii, a patogenicidade de Beauveria bassiana e Paecilomyces fumosoroseus foi comprovada para P. latus. Em condições controladas de temperatura e umidade relativa, estes patógenos ocasionaram morte rápida dos ácaros.

Recentemente, constatou-se em laboratório a patogenicidade por avaliaram a patogenicidade de B. bassiana para $P$. oleivora, verificando níveis de $91 \%$ de mortalidade ao quinto dia após a inoculação. Ao microscópio eletrônico, os ácaros mortos apresentavam na região posterior do corpo um grande número de conídios aderidos, com formação do grande quantidade de micélio no interior do corpo do ácaro (Rossi et al., 2001).

Para Eutetranychus orientalis, o ácaro-marron-dos-citros, observou-se a virulência de um isolado de Verticillium lecanii em condições de laboratório. Todos os estágios de desenvolvimento do ácaro, inclusive os ovos, foram suscetíveis ao patógeno quando aplicado na concentração de $10^{7}$ conídios/ml. A DL50 de $V$. lecanii para esta espécie foi estimada em $1,7 \times 10^{5}$ conídios infectivos/ml (Sewify \& Mabrouk, 1991).

Apesar da ausência de relatos na literatura de outros Hyphomycetes ocorrendo naturalmente em populações de ácaros em citros, estudos que viabilizem sua utilização em pomares, de acordo com uma estratégia adequada de manejo, são importantes, uma vez que muitos patógenos são eficientes no controle de ácaros-pragas em outras culturas. 


\section{SELEÇÃO DE ISOLADOS DE FUNGOS ENTOMOPATOGÊNICOS PARA O CONTROLE DE Brevipalpus phoenicis (Geijskes, 1939)}

\section{Resumo}

Avaliou-se a patogenicidade de 52 isolados de 12 espécies de fungos entomopatogênicos para $B$. phoenicis assim como a produção dos isolados selecionados em meio de cultura sólido (meio completo). Nos ensaios de seleção, ácaros adultos foram confinados em arenas de folhas de citros confeccionadas em placas acrílicas contendo ágar-água a 2\%. Para todos os isolados testados, à exceção de Hirsutella spp. em que se utilizou $1 \times 10^{7}$ conídios/mL, aplicou-se sobre os ácaros uma suspensão de $1 \times 10^{8}$ conídios/mL utilizando-se Torre de Potter (15 libras/pol $\left.{ }^{2}\right)$. Nos ensaios de produção, a avaliação do crescimento e esporulação dos isolados de Hirsutella spp. foi realizada inoculando-se o patógeno em placas de Petri contendo meio sólido completo (M.C.). Nesta etapa avaliaram-se diâmetro das colônias ( $\mathrm{cm}$ ) e número de conídios produzidos por colônia/mL. Dos isolados avaliados, 48 foram patogênicos ao ácaro, causando mortalidades variáveis de $1 \%$ a $100 \%$ após seis dias da inoculação. Os isolados de Hirsutella foram os que causaram maiores mortalidade de B. phoenicis, com índices superiores a 90\%. Na avaliação da produção de Hirsutella spp., o isolado 1269 foi o que apresentou maior crescimento vegetativo e esporulação em meio de cultura completo, duas caracteríticas importantes para a transmissão horizontal do patógeno entre os indivíduos de uma população. 
Palavras-Chave: Ácaro-da-leprose-dos-citros; Controle microbiano; Fungos entomopatogênicos; Hirsutella sp.

\section{SELECTION ISOLATED OF ENTOMOPATOGENIC FUNGI FOR THE CONTROL OF Brevipalpus phoenicis (Geijskes, 1939)}

\section{Summary}

The patogenicity of 52 isolates of entomopatogenic fungi against B. phoenicis and the production of the selected isolates on solid medium were evalueted in this research. Adults of the mite were confined in arenas of citrus leaves placed inside acrylic dishes containing ágar-water (2\%). Suspensions of $1 \times 10^{7}$ conidia/mL of Hirsutella spp. and $1 \times 10^{8}$ conidia/mL of the other pathogens were applied on the mites by a Potter spray tower $\left(15\right.$ pounds/pol $\left.{ }^{2}\right)$. In the production bioassays, the growth and sporulation of Hirsutella's isolates were evaluated. Each strain tested was inoculated in Petri dishes containing complete solid midium (M.C.) and the parameters observed were diameter of the colonies $(\mathrm{cm})$ and number of conidia produced by colonie/mL. From the isolates evaluated, 48 were pathogenic to B. phoenicis with mortality varing from $1 \%$ to $100 \%$ at the sixth day after the inoculation. The isolates of Hirsutella sp. were the most pathogenic against the mite, giving mortality higher than 90\%. The isolate 1269 of Hirsutella sp. showed high levels of vegetative growth and sporulation, two of the most important characteristics for the horizontal transmisson of the pathogen among individuals in a population.

Keywords: Brevipalpus phoenicis; Microbial control; Entomopathogenic fungi; Hirsutella $\mathrm{sp}$. 


\subsection{Introdução}

A utilização de patógenos como agentes de controle em diferentes estratégias do manejo integrado pragas depende, inicialmente, do entendimento das relações entre patógeno, hospedeiro e ambiente. As características de cada componente, bem como a influência que exercem entre si, são determinantes tanto na ocorrência de epizootias e enzootias naturais como no sucesso de um programa de controle microbiano.

As características inerentes aos fatores bióticos, representados por hospedeiro e patógeno, são diretamente afetadas pelos fatores abióticos, climáticos e não-climáticos.

Em relação ao hospedeiro, pode-se considerar os aspectos biológicos e comportamentais, densidade populacional além de sua predisposição ao agente de controle. Quanto ao patógeno, sua reprodução e disseminação, vias de inoculação, transmissão, capacidade de sobrevivência, potencial de inóculo, infectividade, patogenicidade e virulência são importantes. Assim, uma vez conhecidos aspectos da praga-alvo, da cultura envolvida e da capacidade de um patógeno provocar uma epizootia em sua população é possível escolher o agente de controle microbiano mais adequado (Alves \& Leucuona, 1998).

Os fungos são considerados um dos mais importantes entomopatógenos, especialmente devido a ampla variabilidade genética de espécies e isolados, os quais ocorrem atacando diversas pragas em muitas culturas. Devido a estes aspectos, é possível selecionar por meio de bioensaios em laboratório, linhagens virulentas, com características adequadas para serem empregadas como inseticidas microbianos (Alves, 1998).

No Brasil, a avaliação da patogenicidade e virulência em estudos de seleção de isolados para diversas pragas em diferentes culturas foram realizados com êxito e muitos destes permitiram a aplicação prática do material selecionado em condições de campo, em diferentes estratégias de controle (Almeida et al., 1997; Moino Jr. et al., 1998; Lopes, 1999; Tamai, 2002; Tanzini, 2002). 
Desta forma, a seleção de isolados representa a etapa inicial de um programa de controle microbiano, constituindo-se de informação básica e imprescindível para a avaliação do potencial de um patógeno como ingrediente de um inseticida microbiano.

\subsection{Material e Métodos}

\subsubsection{Criação e Manutenção de B. phoenicis em laboratório}

Para a realização dos bioensaios, B. phoenicis foi criado sobre frutos de laranja, os quais foram mantidos no Laboratório de Patologia e Controle Microbiano de Insetos. A população inicial de ácaros foi obtida de uma criação proveniente do laboratório de Resistência de Artrópodes a Pesticidas, do Setor de Entomologia da ESALQ/USP.

Inicialmente, foram coletados em um pomar livre da aplicação de acaricidas e inseticidas, frutos de laranja das variedades "Pêra Rio" e/ou "Valência". Foram selecionados frutos maduros e que apresentavam sintomas de verrugose sobre a casca para o favorecimento da manutenção do ácaro nestas condições.

Os frutos coletados foram encaminhados ao laboratório, lavados em água corrente e secos com papel toalha para limpeza e desinfestação. Após esta etapa, cada um foi submetido a um banho de parafina derretida em $2 / 3$ de sua área total deixando uma arena de aproximadamente $4 \mathrm{~cm}$ de diâmetro sobre a superfície. Esta arena foi delimitada com cola adesiva (Tanglefoot ${ }^{\circledR}$, Grand Rapids, NI, Estados Unidos) para evitar a fuga dos ácaros. Para os frutos sem ou com poucos sintomas de verrugose, foi pincelada sobre a arena de confinamento uma mistura de gesso, areia e água destilada (3:1:1) com o objetivo de simular esta condição.

Em seguida, foram transferidos 50 ácaros adultos por fruto, os quais foram acondicionados em caixas plásticas $(28 \times 43 \times 12 \mathrm{~cm})$ contendo placas de isopor perfuradas e mantidos em sala climatizada $\left(25 \pm 5^{\circ} \mathrm{C} ; 12\right.$ horas de fotofase e $75 \pm 10 \%$ UR) durante um período de 20 dias aproximadamente (Figura 1). 


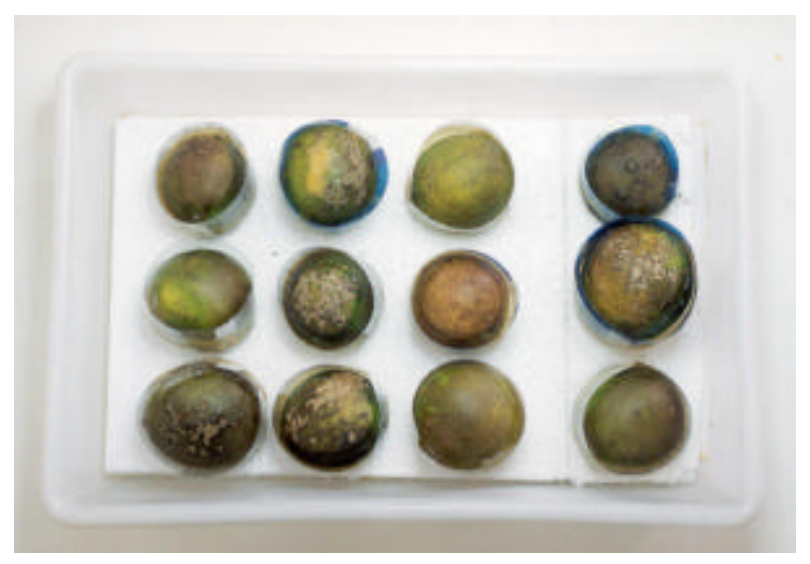

Figura 1 - Bandeja contendo frutos utilizados para a criação de Brevipalpus phoenicis em laboratório (ESALQ/USP).

Após 20 dias foi realizada a substituição dos frutos velhos por novos bem como a transferência dos ácaros, inicialmente com o auxílio de um pincel e em seguida encostando-se a arena de confinamento do fruto velho com a do fruto novo para garantir a infestação dos mesmos.

\subsubsection{Seleção de isolados para o controle de B. phoenicis}

\subsubsection{Plaqueamento dos fungos entomopatogênicos}

Os isolados de fungos entomopatogênicos utilizados nos bioensaios de seleção foram os provenientes do Banco de Patógenos do Laboratório de Patologia e Controle Microbiano de Insetos do Setor de Entomologia e encontram-se armazenados em freezer $\left(-12^{\circ} \mathrm{C}\right)$ na forma de conídios puros, sob óleo mineral e/ou liofilizados. Nesta etapa, foram testados isolados de diferentes espécies, provenientes de locais e hospedeiros distintos (Tabela 1).

Uma amostra de cada isolado testado foi, inicialmente, transferida para placas de Petri esterilizadas contendo meio de cultura completo $\left(0,36 \mathrm{~g}\right.$ de $\mathrm{KH}_{2} \mathrm{PO}_{4} ; 1,05 \mathrm{~g}$ de $\mathrm{NaHPO}_{4} .7 \mathrm{H}_{2} \mathrm{O} ; 0,60 \mathrm{~g}$ de $\mathrm{MgSO}_{4} .7 \mathrm{H}_{2} \mathrm{O} ; 1,0 \mathrm{~g}$ de $\mathrm{KCl} ; 10,0 \mathrm{~g}$ de Glucose; $5 \mathrm{~g}$ de Extrato de Levedura; $20 \mathrm{~g}$ de Agar) previamente autoclavado a $120^{\circ} \mathrm{C}$ por 20 minutos. 
Após a inoculação, as placas foram mantidas durante dez dias em câmara climatizada tipo B.O.D. $\left(26 \pm 0,5^{\circ} \mathrm{C} ; 12\right.$ horas de fotofase e $70 \pm 10 \%$ UR) para o crescimento e esporulação do patógeno.

Tabela 1. Isolados de fungos entomopatogênicos testados para o controle de Brevipalpus phoenicis.

\begin{tabular}{|c|c|c|c|}
\hline Espécie & Isolado & Procedência & Hospedeiro \\
\hline Beauveria bassiana & 447 & Cuiabá (MT) & Solenopsis invicta \\
\hline Beauveria bassiana & 307 & Araras (SP) & Diatraea saccharalis \\
\hline Beauveria bassiana & 457 & Goiás & Euchistus heros \\
\hline Beauveria bassiana & 957 & Piracicaba(SP) & Desconhecido \\
\hline Beauveria bassiana & 1036 & Porto Alegre (RS) & Solenopsis sp. \\
\hline Beauveria bassiana & 1083 & Londrina (PR) & Solo \\
\hline Beauveria bassiana & 1208 & Piracicaba (SP) & Cigarrinha de citros \\
\hline Beauveria bassiana & 1248 & Bebedouro (SP) & Auchenorryncha \\
\hline Beauveria bassiana & 1249 & Boa Esperança do Sul (SP) & Phasmatodea \\
\hline Beauveria bassiana & 1250 & Piracicaba (SP) & Coleoptera \\
\hline Beauveria bassiana & 1258 & Caçú (GO) & Leptopharsa heveae \\
\hline Beauveria bassiana & 1259 & Desconhecida & Auchenorryncha \\
\hline Beauveria bassiana & 1260 & Itiquira (MT) & Leptopharsa heveae \\
\hline Beauveria bassiana & 1273 & Itatinga (SP) & Stictoscarta dissimilis \\
\hline Beauveria bassiana & 1284 & Espírito Santo & Rhynchophorus palmarum \\
\hline Beauveria bassiana & PL63 & Piracicaba (SP) & Atta sp. \\
\hline Beauveria brongniartii & 621 & Alambari (SP) & Solenopsis saevissima \\
\hline Metarhizium anisopliae & 319 & Goiânia (GO) & Mahanarva posticata \\
\hline Metarhizium anisopliae & 798 & Cuiabá (MT) & Solenopsis invicta \\
\hline Metarhizium anisopliae & 860 & Piracicaba (SP) & Macropsis sp. \\
\hline Metarhizium anisopliae & 1037 & Porto Alegre (RS) & Solenopsis sp. \\
\hline
\end{tabular}


Tabela 1. Isolados de fungos entomopatogênicos testados para o controle de Brevipalpus phoenicis.

\begin{tabular}{|c|c|c|c|}
\hline Espécie & Isolado & Procedência & Hospedeiro \\
\hline Metarhizium anisopliae & 1076 & Arapongas (PR) & Solo \\
\hline Metarhizium anisopliae & 1104 & São João do Piauí (PI) & Solo \\
\hline Metarhizium anisopliae & 1172 & Córrego Rico (SP) & Solo \\
\hline Metarhizium anisopliae & 1189 & Corumbá (MT) & Solo \\
\hline Metarhizium anisopliae & 1203 & Pernambuco & Blattodea \\
\hline Metarhizium anisopliae & 1204 & Piracicaba (SP) & Mahanarva fimbriolata \\
\hline Metarhizium anisopliae & 1220 & Piracicaba (SP) & Auchenorryncha \\
\hline Metarhizium anisopliae & 1247 & Turvínia (SP) & Solo \\
\hline Metarhizium anisopliae & 1256 & Concórdia (SP) & Auchenorryncha \\
\hline Metarhizium anisopliae & 1286 & Valparaíso(SP) & Mahanarva fimbriolata \\
\hline Metarhizium anisopliae & E6 & Pernambuco (PE) & Diatraea saccharalis \\
\hline Metarhizium anisopliae & E9 & Boca da Mata (AL) & Mahanarva posticata \\
\hline Metarhizium anisopliae & PL43 & Fleixeira del Estado & Mahanarva sp. \\
\hline Metarhizium anisopliae & PL47 & Rio de Janeiro (RJ) & Mahanava posticata \\
\hline Paecilomyces lillacinus & 508 & Piracicaba (SP) & Solenopsis sp. \\
\hline Paecilomyces lillacinus & 581 & Cuiabá (MT) & Solenopsis invicta \\
\hline Paecilomyces lillacinus & 623 & Cuiabá (MT) & Solo \\
\hline Paecilomyces lillacinus & 774 & Região sul do Brasil & Solenospsis sp. \\
\hline Paecilomyces lillacinus & 827 & Piracicaba (SP) & Solo \\
\hline Paecilomyces fumosoroseus & 1200 & Amélia Rodrigues (BA) & Mahanarva fimbriolata \\
\hline Paecilomyces fumosoroseus & 1297 & Ipeúna (SP) & Lagria vilosa \\
\hline Paecilomyces farinosus & 1205 & Santa Fé do Sul (SP) & Bemisia tabaci \\
\hline Hirsutella thompsonii & 1221 & Itiquira (MT) & Calacarus heveae \\
\hline Hirsutella sp. & 1266 & Pindorama (SP) & Calacarus heveae \\
\hline Hirsutella sp. & 1269 & Caçú (GO) & Calacarus heveae \\
\hline Hirsutella sp. & 1282 & Caçú (GO) & Calacarus heveae \\
\hline Verticillium lecanii & 870 & Piracicaba (SP) & Coccus viridis \\
\hline Verticillium sp. & 972 & Piracicaba (SP) & Coccus viridis \\
\hline Sporothrix sp. & 1224 & Brasília (DF) & Leptopharsa heveae \\
\hline
\end{tabular}


Tabela 1. Isolados de fungos entomopatogênicos testados para o controle de Brevipalpus phoenicis.

\begin{tabular}{llll}
\hline Espécie & Isolado & Procedência & Hospedeiro \\
\hline Sporothrix sp. & 1229 & Itiquira (MT) & Leptopharsa heveae \\
Sporothrix sp. & 1230 & Itiquira (MT) & Leptopharsa heveae \\
\hline
\end{tabular}

\subsubsection{Bioensaios de seleção de isolados}

Os bioensaios de seleção de isolados foram realizados utilizando-se folhas de laranja da variedade "Pêra-Rio" coletadas em um pomar livre da aplicação de defensivos químicos. A desinfestação de cada folha foi realizada mediante a lavagem superficial em água corrente e em seguida a secagem utilizando-se algodão. Após esta etapa, foram recortadas arenas de 2,6cm de diâmetro com a utilização de um vazador de metal.

Cada arena foi colocada em uma placa acrílica $(3,5 \mathrm{~cm}$ de diâmetro) contendo uma mistura de $5 \mathrm{~mL}$ de ágar-água $(2 \%)$ solidificado. Para fixar a folha ao ágar e permitir maior durabilidade da mesma, foi confeccionada sobre esta uma borda de $2 \mathrm{~mL}$ da mistura ágar-água $(2 \%)$ de maneira a delimitar uma arena de confinamento (Figura 2). Em cada arena, foram transferidas 20 fêmeas adultas de B. phoenicis provenientes da colônia estoque. As fêmeas selecionadas foram aquelas que apresentavam alta mobilidade.

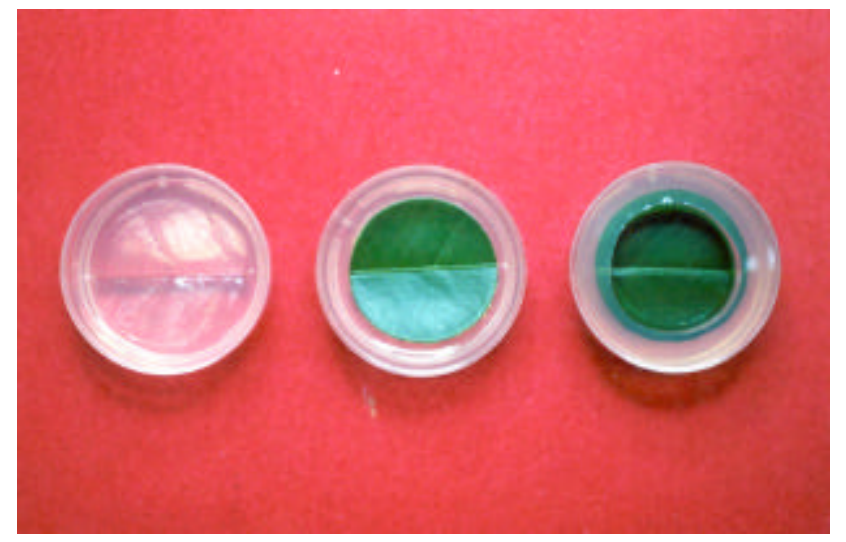

Figura 2 - Arenas de folhas de citros utilizadas nos bioensaios de seleção de isolados para Brevipalpus phoenicis. 
Após o preparo das folhas e transferência dos ácaros, as placas foram pulverizadas com uma suspensão de $1 \times 10^{8}$ conídios/mL para todos os isolados testados, à exceção de Hirsutella sp. o qual foi aplicado na concentração de $10^{7}$ conídios $/ \mathrm{mL}$. A escolha desta concentração foi realizada considerando-se que, para realizar a seleção de materiais patogênicos a determinada praga, é necessária a aplicação de um grande número de conídios viáveis. Para Hirsutella spp., não foi possível a obtenção de concentrações superiores a $1 \times 10^{7}$ conídios $/ \mathrm{mL}$, uma vez que a produção de conídios aéreos deste patógeno em meio sólido é baixa. Como critérios de seleção, os isolados considerados mais eficientes foram aqueles com maior capacidade de infecção dos conídios aéreos e mortalidade sobre o ácaro.

O tratamento testemunha consistiu da aplicação de água estéril mais espalhante adesivo a $0,01 \%$ (Tween $40^{\circledR}$ ). Além do tratamento testemunha, foi utilizado em todos os bioensaios um isolado padrão (isolado 447 de $B$. bassiana), pulverizado na concentração de $10^{8}$ conídios $/ \mathrm{mL}$. A escolha deste isolado como padrão deu-se em função de ser um material registrado e selecionado para controle de outras pragas (Alves, 1998).

Para o preparo da suspensão, as placas de Petri contendo o patógeno foram raspadas com o auxílio de uma espátula de borracha esterilizada e o fungo transferido para tubos de dieta contendo $10 \mathrm{~mL}$ de água destilada mais espalhante adesivo a 0,01\% (Tween 40). Após a realização de três diluições em série, os conídios foram contados em câmara de Neubauer e foi preparada, à partir da suspensão original, a suspensão que foi pulverizada.

Para cada isolado testado foram pulverizadas 5 placas acrílicas com os ácaros, constituindo-se 5 repetições por tratamento e um total de 20 ácaros por repetição. A pulverização foi realizada em Torre de Potter (Burkard Manufactring Rickmansworth, Herts, Reino Unido) calibrada a 15 libras/pol ${ }^{2}$, utilizando-se $2 \mathrm{~mL}$ da suspensão de conídios $\left(0,2 \mu l\right.$ da suspensão/ $\left.\mathrm{cm}^{2}\right)$.

Em seguida à pulverização, as placas acrílicas foram mantidas alguns minutos em ambiente para a secagem da suspensão e em seguida transferidas para caixas plásticas $(11 \times 33 \times 20,5 \mathrm{~cm})$ fechadas, contendo uma folha de papel toalha umedecida no fundo e 
mantida em câmara climatizada tipo B.O.D. $\left(26 \pm 0,5^{\circ} \mathrm{C} ; 12\right.$ horas de fotofase e $70 \pm 10 \%$ UR) durante todo o período de avaliação.

As avaliações foram diárias até o sexto dia após a aplicação, registrando-se o número de ácaros mortos em cada disco de folha. Como critério de avaliação, foram considerados mortos apenas os ácaros que não apresentavam movimentação do corpo e das pernas, não sendo considerados aqueles moribundos ou mesmo com sintomas de infecção.

Os ácaros mortos foram separados, transferidos para recipientes acrílicos contendo a mistura ágar-água $(2 \%)$ e estes mantidos em câmara B.O.D. $\left(26 \pm 0,5^{\circ} \mathrm{C} ; 12\right.$ horas de fotofase e $70 \pm 10 \%$ UR) durante 5 dias para a confirmação da morte pelo fungo. Assim, após a esporulação, cada ácaro foi montado em lâmina com meio Hoyer + Azul láctico (2:1) e observado em microscópio ótico para a visualização de estruturas do patógeno.

Os valores de mortalidade foram corrigidos pela fórmula proposta por Abbott (1925) e submetidos à análise gráfica.

\subsubsection{Produção de isolados de Hirsutella sp.}

Nesta etapa avaliou-se a produção de quatro isolados de Hirsutella sp. selecionados para o controle do ácaro B. phoenicis. em meio de cultura completo (M.C.).

Inicialmente, inóculos puros de cada isolado do patógeno foram produzidos e incubados a $26 \pm 1^{\circ} \mathrm{C}$ e fotofase 12 horas em câmara climatizada tipo B.O.D. durante um período de 15 dias.

A partir do material puro, uma pequena porção do fungo foi transferida para placas de Petri contendo meio de cultura completo. Com o auxílio de uma alça de platina estéril o patógeno foi transferido para as placas em três pontos eqüidistantes para promover o crescimento de três colônias independentes. Para cada isolado testado foram preparadas 5 placas e estas incubadas em B.O.D. $\left(26 \pm 1^{\circ} \mathrm{C}\right.$ e fotofase 12 horas) durante 15 dias.

Os parâmetros avaliados foram o diâmetro das colônias $(\mathrm{cm})$ e o número de conídios produzidos/colônia. Para estimar o número de conídios/colônia, cada uma foi cortada com o auxílio de um vazador de metal e inserida em um tubo de dieta estéril 
contendo água destilada mais espalhante adesivo a 0,01\% (Tween 40). Após uma diluição, contou-se o número de conídios produzidos com o auxílio de câmara de Neubauer.

Os resultados obtidos foram submetidos a análise de variância e as médias comparadas pelo Teste de Tukey (5\% de probabilidade).

\subsection{Resultados e Discussão}

\subsubsection{Seleção de Isolados}

Os valores de mortalidade corrigida e confirmada de adultos de B. phoenicis referentes aos 52 isolados de fungos entomopatogênicos constam da Tabela 2.

Tabela 2. Mortalidade total, acumulada e corrigida de adultos de Brevipalpus phoenicis, ao terceiro e sexto dias após a inoculação com diferentes isolados de fungos entomopatogênicos.

\begin{tabular}{lllll}
\hline $\begin{array}{l}\text { Isolado } \\
\text { Grupo } 1\end{array}$ & \% de mortalidade acumulada e corrigida & \multicolumn{2}{c}{ \% de mortalidade confirmada } \\
& $\mathbf{3 ~ d . a . i . ~}$ & $\mathbf{6}$ d.a.i. & $\mathbf{3}$ d.a.i. & 6 d.a.i. \\
\hline $447^{*}$ & 0,56 & 9,77 & 1,125 & 10,62 \\
PL63 & 0,00 & 9,00 & 0,00 & 7,5 \\
621 & 2,00 & 3,09 & 0,00 & 3,00 \\
1273 & 2,04 & 17,35 & 3,00 & 17,00 \\
1036 & 2,00 & 16,49 & 2,00 & 15,00 \\
1083 & 1,00 & 14,43 & 1,00 & 16,00 \\
1208 & 3,06 & 22,45 & 4,00 & 22,00 \\
1248 & 0,00 & 14,43 & 0,00 & 16,00 \\
1249 & 0,00 & 7,00 & 0,00 & $1.4,00$
\end{tabular}


Tabela 2. Mortalidade total, acumulada e corrigida de adultos de Brevipalpus phoenicis, ao terceiro e sexto dias após a inoculação com diferentes isolados de fungos entomopatogênicos.

\begin{tabular}{|c|c|c|c|c|}
\hline \multirow{2}{*}{$\begin{array}{l}\text { Isolado } \\
\text { Grupo } 1\end{array}$} & \multicolumn{2}{|c|}{ \% de mortalidade acumulada e corrigida } & \multicolumn{2}{|c|}{ \% de mortalidade confirmada } \\
\hline & 3 d.a.i. & 6 d.a.i. & 3 d.a.i. & 6 d.a.i. \\
\hline 1250 & 1,00 & 6,00 & 1,00 & 5,00 \\
\hline 1284 & 0,00 & 0,00 & 0,00 & 0,00 \\
\hline 1258 & 1,00 & 5,05 & 0,00 & 3,00 \\
\hline 1259 & 1,00 & 12,12 & 1,00 & 11,00 \\
\hline 1260 & 2,00 & 5,15 & 1,00 & 5,00 \\
\hline 957 & 0,00 & 6,25 & 0,00 & 8,00 \\
\hline 457 & 4,04 & 10,42 & 4,00 & 13,00 \\
\hline 1037 & 2,00 & 15,00 & 3,00 & 13,00 \\
\hline E9 & 5,00 & 24,00 & 5,00 & 21,00 \\
\hline 1104 & 8,08 & 29,30 & 7,00 & 21,00 \\
\hline 860 & 2,00 & 13,00 & 1,00 & 12,00 \\
\hline 798 & 2,00 & 7,00 & 1,00 & 7,00 \\
\hline 319 & 1,00 & 5,00 & 0,00 & 8,00 \\
\hline 307 & 5,05 & 10,42 & 6,00 & 12,00 \\
\hline 1203 & 3,00 & 22,68 & 1,00 & 23,00 \\
\hline 1204 & 6,00 & 29,00 & 5,00 & 24,00 \\
\hline 1220 & 7,00 & 16,00 & 7,00 & 16,00 \\
\hline 1172 & 2,00 & 4,00 & 1,00 & 4,00 \\
\hline 1076 & 0,00 & 6,32 & 1,00 & 8,00 \\
\hline E6 & 6,00 & 6,06 & 4,00 & 5,00 \\
\hline PL47 & 2,00 & 5,15 & 1,00 & 6,00 \\
\hline 1247 & 5,00 & 8,25 & 2,00 & 8,00 \\
\hline 1256 & 5,00 & 19,00 & 3,00 & 16,00 \\
\hline 1286 & 2,00 & 23,71 & 2,00 & 26,00 \\
\hline 1189 & 7,00 & 18,00 & 6,00 & 14,00 \\
\hline PL43 & 5,32 & 24,24 & 6,00 & 23,00 \\
\hline
\end{tabular}


Tabela 2. Mortalidade total, acumulada e corrigida de adultos de Brevipalpus phoenicis, ao terceiro e sexto dias após a inoculação com diferentes isolados de fungos entomopatogênicos.

\begin{tabular}{lllll}
\hline Isolado & \% de mortalidade acumulada e corrigida & \multicolumn{2}{c}{ \% de mortalidade confirmada } \\
Grupo 1 & 3 d.a.i. & 6 d.a.i. & 3 d.a.i. & 6 d.a.i. \\
\hline 581 & 2,00 & 8,00 & 0,00 & 15,00 \\
623 & 0,00 & 3,00 & 0,00 & 2,00 \\
774 & 0,00 & 0,00 & 0,00 & 1,00 \\
508 & 0,00 & 0,00 & 1,00 & 3,00 \\
827 & 1,01 & 2,08 & 1,00 & 4,00 \\
1200 & 0,00 & 16,49 & 0,00 & 14,00 \\
1205 & 5,00 & 23,23 & 5,00 & 18,00 \\
1297 & 0,00 & 0,00 & 0,00 & 0,00 \\
972 & 4,00 & 22,68 & 2,00 & 24,00 \\
870 & 1,00 & 1,01 & 0,00 & 1,00 \\
1224 & 3,00 & 10,31 & 1,00 & 7,00 \\
1229 & 3,00 & 5,15 & 3,00 & 8,00 \\
1230 & 0,00 & 4,16 & 0,00 & 4,00 \\
Grupo 2 & & & & 83,00 \\
$1221 * *$ & 13,27 & 94,92 & 16,00 & 95,00 \\
$1266 * *$ & 39,175 & 100 & 34,00 & 75,00 \\
$1269 * *$ & 24,49 & 97,87 & 23,00 & 89,00 \\
$1282 * *$ & 4,00 & 92,78 & 4,00 & 83 \\
\hline Para este & $1501 a d 0$ & $v a x$ & 900 \\
\hline
\end{tabular}

* Para este isolado (padrão), os valores de mortalidade ao terceiro e sexto dias após a inoculação são a média de todos os experimentos realizados.

** Para os isolados de Hirsutella sp., a suspensão aplicada foi de $1 \times 10^{7}$ conídios $/ \mathrm{mL}$.

De acordo com os valores de mortalidade total, acumulada e corrigida de ácaros, é possível separar os isolados testados em dois grupos distintos: o primeiro reúne cepas de B. bassiana, B. brongniartii, M. anisopliae, Sporothrix sp., Verticillium spp. e Paecilomyces spp.; e o segundo grupo com cepas de Hirsutella spp. (Figura 3). 


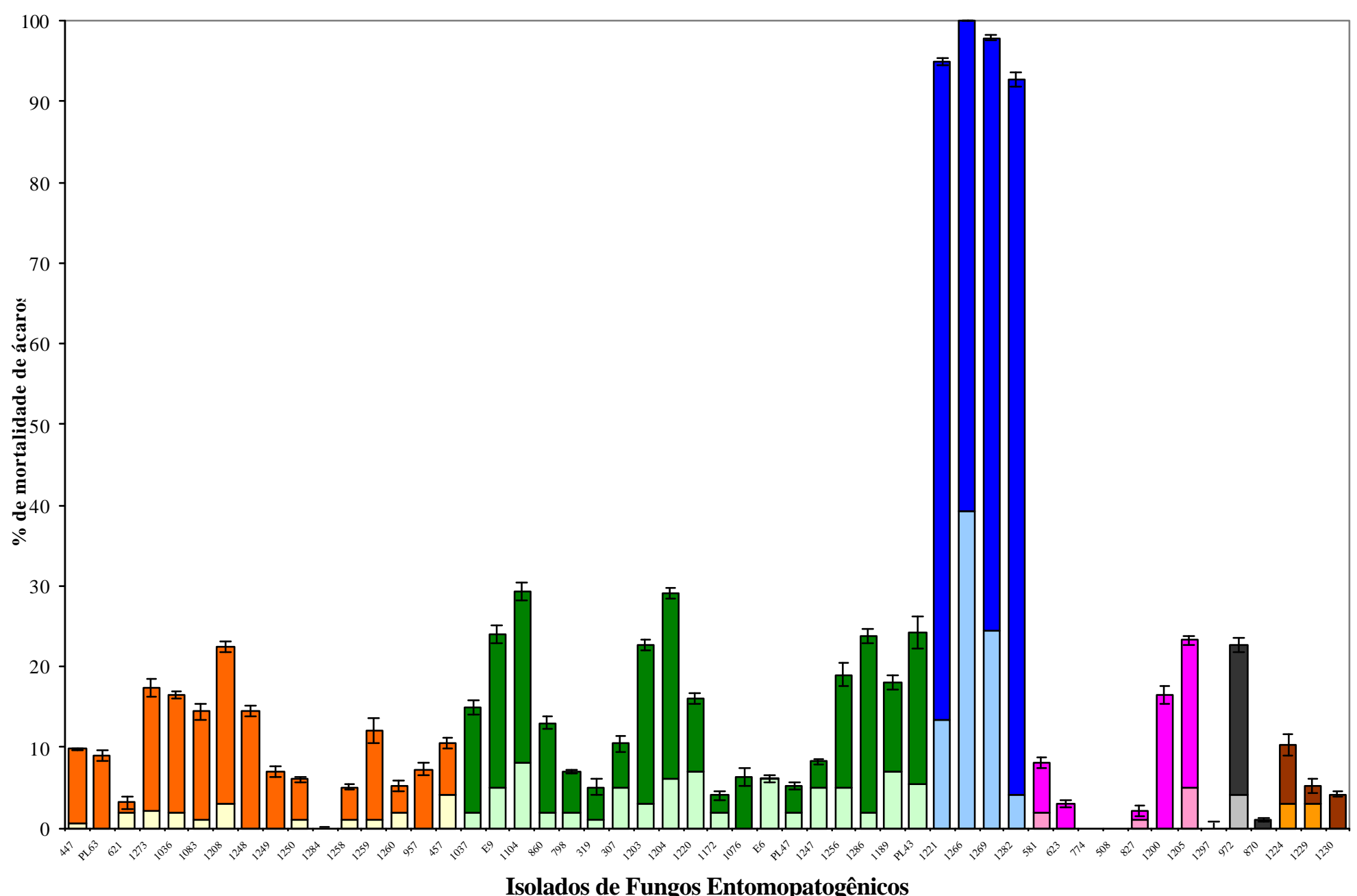

Figura 3 - Porcentagem de mortalidade corrigida de Brevipalpus phoenicis, inoculados com diferentes isolados de fungos entomopatogênicos, ao terceiro (cor clara) e sexto (cor escura) dias da aplicação. 
Para o primeiro grupo, apesar da grande variabilidade genética das linhagens, observou-se índices de mortalidade de ácaros inferiores a 30\%, com uma variação de 0\% a 29,30\%, após o sexto dia da aplicação. A maioria dos trabalhos de seleção de isolados não relacionam a patogenicidade e virulência de um material à sua origem, podendo este ocasionar altos índices de mortalidade em uma ampla gama de hospedeiros como foi comprovado para pragas de grãos armazenados, Heterotermes tenuis, T. urticae, Frankliniella occidentalis, Bemisia tabaci, entre outros (Moino Júnior et al., 1998; Almeida et al., 1997, Tamai, 1998; Lopes, 1999; Ramos, 2001). Esta variação da patogenicidade é, com frequiência, observada em bioensaios de seleção, podendo estar associada à fatores como baixa virulência do isolado, especificidade, tolerância do hospedeiro, entre outros (Alves, 1998).

Variações intraespecíficas na mortalidade foram observadas entre os isolados de $B$. bassiana e M. anisopliae, os quais ocasionaram ao terceiro e sexto dias após a aplicação, índices médios de mortalidade de $2 \%$ e $10,4 \%$ e $3,9 \%$ e $15,1 \%$, respectivamente.

Apesar de haverem poucos relatos da ocorrência natural destes fungos em ácaros fitófagos, outras espécies mostraram-se bastante susceptíveis a atuação destes organismos, diferentemente do constatado para B. phoenicis neste estudo. A avaliação de isolados de B. bassiana, M. anisopliae, entre outros, para o ácaro rajado (T. urticae), em condições de laboratório e semi-campo, comprovou a alta virulência de cepas de $B$. bassiana, possibilitando o desenvolvimento de um programa de controle microbiano para esta praga em casa-de-vegetação (Tamai, 2002). Em citros, a aplicação de $1 \times 10^{8}$ conídios/mL do isolado 447 de $B$. bassiana proporcionou índices de mortalidade superiores a 90\% de P.oleivora após 5 dias da inoculação (Rossi et al., 2001).

O isolado 447 de B. bassiana, utilizado como padrão nos 16 experimentos de seleção, apresentou média de mortalidade corrigida de $9,77 \%$, ao sexto dia da aplicação. Para T. urticae, este isolado apresentou mortalidade corrigida de $22,5 \%$ ao sexto dia da aplicação, sendo considerado pouco patogênico para este ácaro, diferentemente do observado para P. oleivora (Tamai et al., 1999; Rossi et al., 2001). Para outras espécies de insetos, de uma forma geral, este isolado apresenta boa eficiência e já foi selecionado 
como promissor em programas de controle microbiano (Alves, 1986; Stimac et al., 1989; Alves, 1998).

A pequena variação da mortalidade corrigida do isolado padrão entre os experimentos, representou uma indicação da variabilidade da população de ácaros utilizada, bem como uma garantia de que algumas condições externas não exerceram influência na mortalidade dos ácaros (Tabela 3).

Tabela 3. Mortalidade total, acumulada e corrigida de adultos Brevipalpus phoenicis inoculados com uma suspensão de $1 \times 10^{8}$ conídios $/ \mathrm{mL}$ do isolado padrão de Beauveria bassiana (447) utilizado nos bioensaios de seleção.

\begin{tabular}{ccccc}
\hline \multirow{2}{*}{ Experimento } & & \multicolumn{3}{c}{ \% de mortalidade total, acumulada e corrigida } \\
& $\mathbf{3 ~ d . a . i . ~}$ & $\mathbf{4}$ d.a.i. & $\mathbf{5}$ d.a.i. & $\mathbf{6 ~ d . a . i . ~}$ \\
\hline $\mathbf{1}$ & 0,00 & 3,03 & 4,04 & 8,16 \\
$\mathbf{3}$ & 1,00 & 2,00 & 7,00 & 11,00 \\
$\mathbf{4}$ & 1,01 & 8,08 & 9,09 & 27,27 \\
$\mathbf{5}$ & 0,00 & 2,00 & 7,00 & 10,00 \\
$\mathbf{6}$ & 0,00 & 1,01 & 4,00 & 13,00 \\
$\mathbf{7}$ & 1,00 & 2,00 & 3,06 & 7,216 \\
$\mathbf{8}$ & 0,00 & 0,00 & 2,06 & 6,25 \\
$\mathbf{9}$ & 0,00 & 0,00 & 2,15 & 6,31 \\
$\mathbf{1 0}$ & 0,00 & 1,02 & 6,12 & 8,16 \\
$\mathbf{1 1}$ & 0,00 & 3,03 & 8,08 & 14,14 \\
$\mathbf{1 2}$ & 1,00 & 1,00 & 3,03 & 5,05 \\
$\mathbf{1 3}$ & 2,00 & 4,00 & 9,09 & 10,31 \\
$\mathbf{1 4}$ & 1,00 & 2,00 & 7,00 & 13,00 \\
$\mathbf{1 5}$ & 0,00 & 2,00 & 9,18 & 13,40 \\
$\mathbf{1 6}$ & 0,00 & 0,00 & 1,01 & 3,12 \\
$\mathbf{M e ́ d i a}$ & 0,56 & 0,00 & 1,06 & 3,19 \\
\hline & & 2,011 & 5,122 & 9,97 \\
\hline
\end{tabular}


Os isolados 1104, 1203 e 1204 de M. anisopliae e o isolado 927 de Verticilium sp. causaram um aumento considerável na mortalidade de ácaros após o terceiro dia da inoculação. Apesar da baixa mortalidade, foi possível observar, ao sexto dia da inoculação, ácaros vivos com sintomas de infecção, os quais seriam, dentro de algumas horas, mortos pelo patógeno. Este fato pode ser explicado devido às características do patógeno, como tempo de germinação e colonização, os quais são variáveis e podem determinar a virulência do isolado e seu tempo de incubação necessário para que promova a morte do hospedeiro (Alves, 1998).

A principal vantagem da utilização prática de $M$. anisopliae ou Verticillium sp. para o controle da praga alvo é a facilidade de produção em larga escala, o que viabiliza a utilização destes agentes de maneira inundativa (Alves \& Pereira, 1998). Para os ácaros cujos danos à cultura são diretos, a utilização de linhagens patogênicas porém pouco virulentas é possível, desde que o intervalo entre a aplicação e o controle efetivo não comprometa a produtividade da cultura. No caso de B. phoenicis em citros, a adoção desta estratégia pode ser arriscada devido à capacidade desta espécie transmi tir um vírus. Como esta transmissão é do tipo persistente-circulativa, o tempo decorrido entre a aquisição do vírus pelo ácaro e sua transmissão é menor do que o tempo necessário para a infecção e morte do ácaro pelo fungo, podendo comprometer a eficiência de controle da doença. Por outro lado, a alteração do comportamento de hospedeiros infectados por fungos, especialmente a redução de sua alimentação, é um aspecto que pode alterar e reduzir a taxa de transmissão do vírus pelo ácaro (Hajek \& Leger, 1994). Desta forma, o controle associado entre estes fungos e acaricidas compatíveis, desde que tenham um efeito sinérgico, é uma possibilidade que pode ser avaliada, especialmente no contexto de manejo da resistência (Alves et al., 2000).

Dentre os isolados de Paecilomyces spp., a espécie P. farinosus (isolado 1205) foi a que apresentou maior taxa de mortalidade corrigida (5\% e $23 \%$, após o terceiro e sexto dias da inoculação) em comparação às demais. A ausência ou baixa patogenicidade destas espécies, especialmente $P$. lillacinus, está relacionada ao fato destes serem patógenos que atacam organismos que vivem no solo, como nematóides e alguns insetos (Alves, 1998). 
Sporothrix spp. apresentaram média de mortalidade corrigida de $2 \%$ e $6,5 \%$ de ácaros, ao terceiro e sexto dias, respectivamente. Estes organismos, freqüentemente aplicados como para controle de Leptopharsa heveae em seringueira, apresentam-se pouco patogênicos para Tenuipalpus heveae e Calacarus heveae, dois ácaros que ocorrem nesta cultura (M.R.Tanzini, 2002. Comunicação pessoal).

Em todas as espécies do grupo 1, altos índices de mortalidade confirmada foram observados, indicando que, do número total de mortos, grande parte foi devido à infecção pelo patógeno.

Os sintomas visuais de B. phoenicis infectados e mortos pelo patógeno foram, de maneira geral, semelhantes entre as espécies de fungos testadas. Os ácaros contaminados por M. anisopliae, B. bassiana, B. brongniartti, Paecilomyces spp. e Sporothrix sp. apresentaram alterações na coloração do tegumento e na movimentação, com evidente enrijecimento ventral das pernas. Quando incomodados pelo toque do pincel ou pela incidência direta de luz, os indivíduos doentes exibiam um comportamento de "jogar" o corpo para trás mantendo apenas as pernas posteriores aderidas ao substrato. Para o isolado 972 de Verticillium spp., à partir do quinto dia de inoculação, os ácaros apresentavam crescimento de micélio por toda a região do idiossoma e lentidão dos movimentos, além dos sintomas anteriormente descritos. Todos os indivíduos mortos apresentavam as pernas enrijecidas ventralmente e mudanças na coloração do tegumento.

Os isolados do segundo grupo são de Hirsutella thompsonii (1221) e Hirsutella spp. (1269, 1282 e 1266). Estes materiais, mesmo tendo sido aplicados em uma concentração dez vezes menor que os demais fungos $\left(1 \times 10^{7}\right.$ conídios $\left./ \mathrm{mL}\right)$, promoveram maior taxa de mortalidade em B. phoenicis. Esta é uma característica interessante e que indica a superioridade desta espécie em relação às demais, uma vez que quanto menor a necessidade de propágulos infectivos do patógeno aderidos ao corpo hospedeiro para que ocorra o desenvolvimento da doença, maior a virulência de um material (Oduor et al., 1997). Para Varroa destructor, uma espécie de ácaro que parasita abelhas, a aplicação de suspensões de $1 \times 10^{6}$ conídios/ml de diferentes isolados de Hirsutella spp. proporcionou índices de mortalidade de 97\% (7 d.a.i) semelhantes aos obtidos pela 
aplicação de $1 \times 10^{8}$ conídios/ml de M. anisopliae, V. lecanii, B. bassiana e Paecilomyces app. (Shaw et al., 2002).

À exceção do isolado 1282, aumentos expressivos nas taxas de mortalidade foram observados a partir do terceiro dia da inoculação do patógeno. No último dia de avaliação, os índices de mortalidade total, acumulada e corrigida foram superiores a $90 \%$ para os isolados 1221, 1282 e 1269 e $100 \%$ para 1266 (Figura 4).

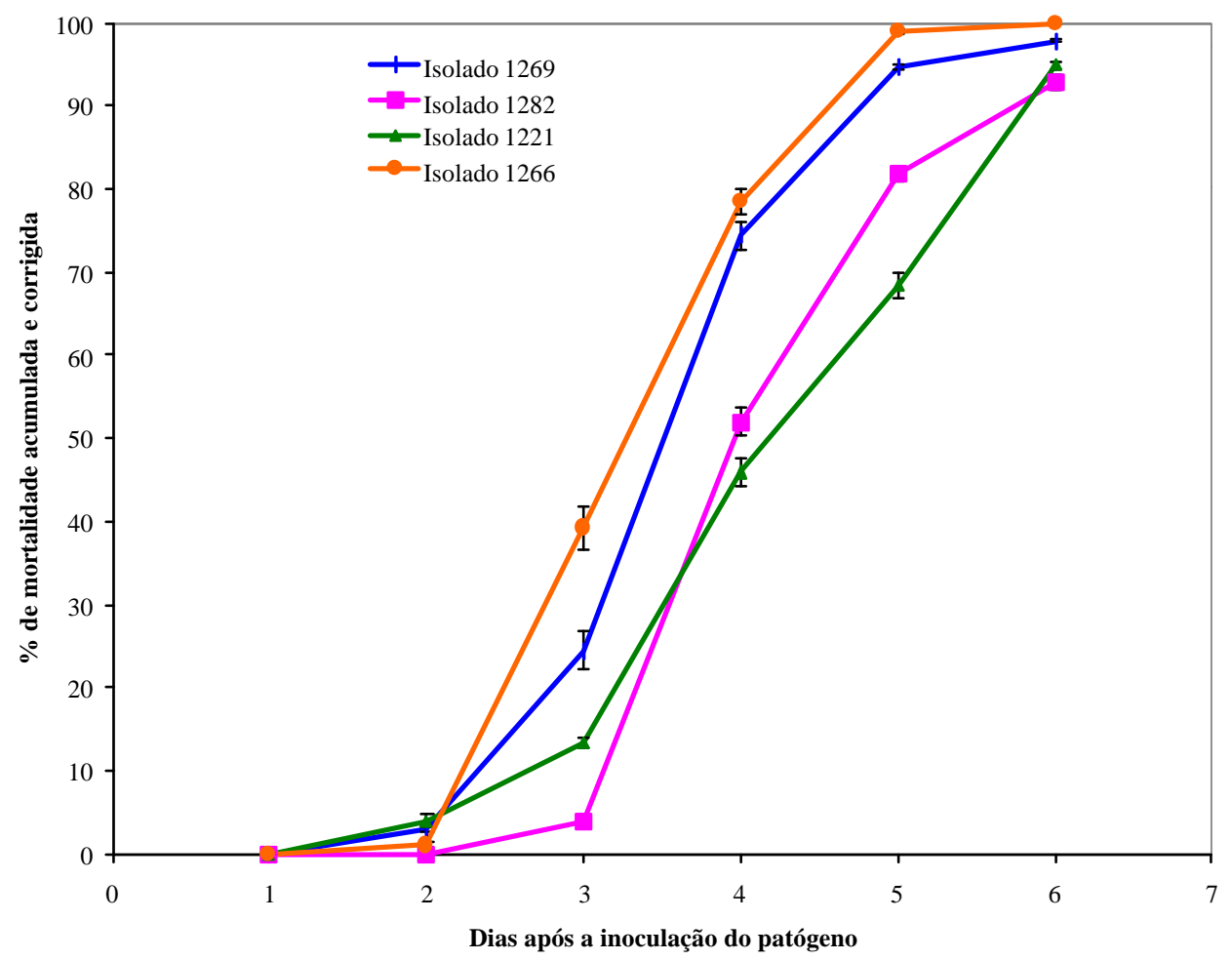

Figura 4 - Mortalidade acumulada e corrigida ( \pm desvio padrão da média) de Brevipalpus phoenicis, inoculados com uma suspensão de $1 \times 10^{7}$ conídios $/ \mathrm{mL}$ de Hirsutella sp.

Diversas espécies de Hirsutella são consideradas importantes inimigos naturais de várias espécies de ácaros, pois causam altos índices de mortalidade em populações de campo (Lipa, 1971; Alves, 1998; McCoy, 1996; Acevedo \& Rosas, 2000; Shaw et al., 2002). A alta virulência e especificidade deste grupo para ácaros pode estar relacionada 
a uma série de eventos decorrentes do ciclo de relações patógeno-hospedeiro (Alves, 1998).

A ação de metabólitos secundários produzidos durante o processo de colonização de Hirsutella spp. pode ser um dos fatores responsáveis pela rapidez com que este fungo é capaz de matar adultos de B. phoenicis, como já foi observado para outros organismos. Experimentos realizados com larvas de Galleria mellonella e Drosophila melanogaster e adultos de $P$. oleivora constataram que toxinas de $H$. thompsonii var. thompsonii são produzidas e liberadas no início do crescimento micelial deste patógeno, ocasionando altos índices de mortalidade após um tempo que pode ser variável de acordo com o hospedeiro e concentração da toxina (Vey et al., 1993; Omoto \& McCoy, 1998). A ação destes metabólitos enzimáticos pode ser um fator determinante na virulência e patogenicidade do isolado (Hajek \& Leger, 1994). Mesmo assim, a comprovação destas evidências somente é possível se a ausência ou remoção da toxina de um sistema diminui ou elimina estes dois fatores (Roberts \& Krasnoff, 1998).

Os sintomas da doença também foram observados a partir do terceiro dia da inoculação em ácaros moribundos e mortos, sendo estes muito semelhantes ao que foi constatado para os outros isolados. Ao microscópio ótico foi possível observar a presença de hifas no interior e externamente ao corpo do hospedeiro, com presença de conidióforos emergindo por meio das aberturas oral e posteriores (Figura 5). De acordo com a literatura, os eriofiídeos $P$. oleivora; Aceria vaccinii e $C$. heveae quando infectados por $H$ thompsonii, apresentam sintomas semelhantes aos observados em $B$. phoenicis (Lipa, 1971; Baker \& Neunzig, 1968; Tanzini et al., 2000). 


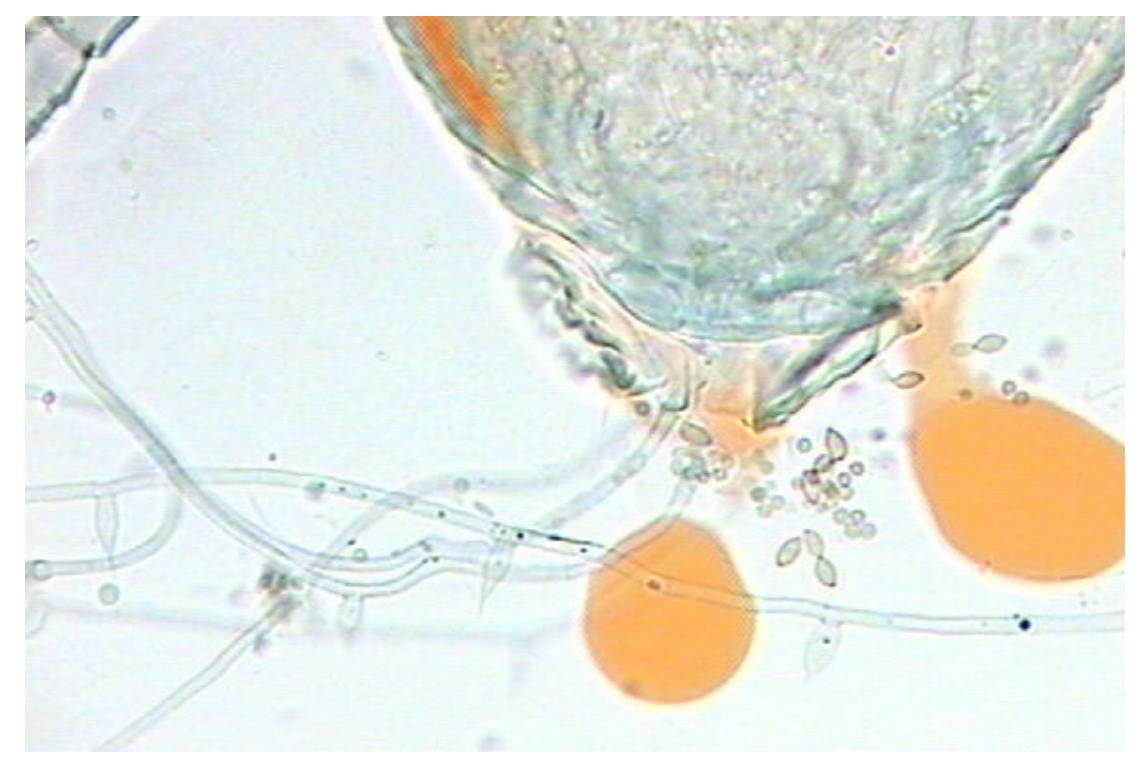

Figura 5 - Detalhe de hifas e conidióforos de Hirsutella sp. emergindo de abertura anal de Brevipalpus phoenicis (Aumento: 40 vezes).

Para todos os isolados deste grupo, a porcentagem de mortalidade confirmada ao terceiro e sexto dias de aplicação foi elevada (Tabela 1). Esta capacidade de cada indivíduo infectado produzir propágulos do patógeno é um aspecto importante e que pode levar ao desencadeamento de epizootias em campo, uma vez que, em condições ambientais favoráveis, mantém ou aumenta o potencial de inóculo em uma determinada área (Alves \& Lecuona, 1998).

Em comparação às outras espécies de fungos analisadas neste trabalho, os testes de patogenicidade revelaram a superioridade de Hirsutella spp. para B. phoenicis, em condições de laboratório. Apesar do pequeno número de cepas avaliadas, ficou evidente que para esta praga, há necessidade de se efetuar outros estudos que complementem a etapa de seleção deste fungo, como a avaliação de outros isolados, testes de virulência, influência de radiação, temperatura e umidade, ciclo de vida, disseminação e produção. Todos estes estudos complementares são de grande importância para o desenvolvimento deste agente como inseticida microbiano. 


\subsubsection{Produção de Isolados de Hirsutella spp.}

A patogenicidade de um determinado isolado é uma aspecto de grande importância para o processo de seleção, pois sendo uma característica qualitativa, determina a capacidade do microrganismo provocar a doença em um hospedeiro (Alves \& Lecuona, 1998). Após essa etapa, há a necessidade de conhecer outros aspectos inerentes aos patógenos para que, dentro de um grupo de linhagens que apresentem alta patogenicidade, seja possível separar os que apresentam potencial para serem utilizados em programas de controle microbiano. Um destes aspectos é a capacidade de produção do fungo em determinado meio de cultura durante as fases iniciais e finais do processo produtivo, com o objetivo de avaliar sua capacidade de crescimento e desenvolvimento (Alves \& Pereira, 1998).

Os resultados das avaliações do crescimento micelial e do número de conídios produzidos por cada isolado de Hirsutella spp. quando cultivados em meio sólido completo (M.C.) estão apresentados nas Tabelas 4, 5, 6 e 7.

Tabela 4. Análise de variância para o fator diâmetro de colônias $(\mathrm{cm})$ de quatro isolados de Hirsutella spp.

\begin{tabular}{lccccc}
\hline Causas de variação & G.L. & S.Q. & Q.M. & Valor de F & Prob.>F \\
\hline Diâmetro & 3 & 5.4723637 & 1.8241212 & 8.1518 & $0.00031^{* *}$ \\
Resíduo & 52 & 11.6360298 & 0.2237698 & & \\
Total & 55 & 17.1083935 & & & \\
\hline
\end{tabular}

** significativo a 1 e $5 \%$ de probabilidade 
Tabela 5. Teste de Tuckey para médias de diâmetro de colônias $(\mathrm{cm})$ de quatro isolados de Hirsutella spp.

\begin{tabular}{|c|c|c|c|c|}
\hline \multicolumn{2}{|c|}{ Isolados } & Número de repetições & o médio das & olônias ${ }^{1}$ \\
\hline \multicolumn{2}{|l|}{1269} & 13 & 2,561 a $A$ & \\
\hline \multicolumn{2}{|l|}{1266} & 13 & 2,507 a $\mathrm{A}$ & \\
\hline \multicolumn{2}{|l|}{1221} & 15 & $2,000 \mathrm{~b} \mathrm{AB}$ & \\
\hline \multicolumn{2}{|l|}{1282} & 15 & $1,840 \mathrm{~b} \mathrm{~B}$ & \\
\hline \multicolumn{5}{|c|}{$\begin{array}{l}\text { Médias seguidas por letras distintas diferem entre si ao nível de } 5 \% \text { e } 1 \% \text { de } \\
\text { probabilidade, respectivamente. }\end{array}$} \\
\hline \multicolumn{5}{|c|}{$\begin{array}{l}\text { Tabela 6. Análise de variância para o fator produção (conídios/colônias) de quatro } \\
\text { isolados de Hirsutella spp. }\end{array}$} \\
\hline $\begin{array}{l}\text { Causas de } \\
\text { variaçãa }\end{array}$ & G.L. & S.Q. & Valor de $F$ & Prob.>F \\
\hline Produção & 3 & 1309351187942.613 & 30.8673 & $0.00001 * *$ \\
\hline Resíduo & 52 & 2205773069743.6 & & \\
\hline Total & 55 & 133826633571.41 & & \\
\hline
\end{tabular}

** significativo a 1 e $5 \%$ de probabilidade

Tabela 7. Teste de Tuckey para médias de produção (conídios/colônias) de quatro isolados de Hirsutella sp.

\begin{tabular}{|c|c|c|}
\hline Isolados & Número de repetições & Produção de conídios/colônias ${ }^{\top}$ \\
\hline 1269 & 13 & $7,028 \times 10^{5}$ a $\mathrm{A}$ \\
\hline 1282 & 15 & $7,153 \times 10^{5}$ a $\mathrm{A}$ \\
\hline 1266 & 13 & $4,110 \times 10^{5}$ b B \\
\hline 1221 & 15 & $8,046 \times 10^{4}$ c $\mathrm{C}$ \\
\hline
\end{tabular}


De acordo com a análise de variância, houve diferenças estatísticas do crescimento micelial e da produção de conídios entre os quatro isolados de Hirsutella spp. a 5\% e 1\% de probabilidade. Exceto entre o 1282 e 1269, as variações nos parâmetros de produção avaliados podem ser explicadas em decorrência da diferença genética entre os isolados testados, os quais são provenientes de hospedeiros e origens distintas entre si. Deste grupo, a única linhagem identificada taxonomicamente até "espécie" é o 1221, um exemplar de $H$. thompsonii. Os demais materiais somente foram classificados em nível de gênero, podendo pertencer a outras espécies. Embora estes aspectos morfológicos possam ser indicativos das diferenças nos padrões genotípicos dos materiais, a caracterização específica somente pode ser comprovada mediante análises bioquímicas, serológicas, moleculares enzimáticas e de DNA (Sosa-Gómez et al., 1998).

Quanto ao crescimento da colônia, os isolados 1269 e 1266 foram os que apresentaram maiores médias, indicando maior desenvolvimento em relação aos demais. Apesar de não terem sido observadas diferenças estatísticas entre estes materiais, 1269 foi numericamente superior ao 1266. Em relação à produção, determinada pelo número de conídios produzidos por colônia, 1269 e 1282 apresentaram os melhores índices, não diferindo entre si estatisticamente. Para os dois parâmetros avaliados, o pior isolado foi o 1221, o qual apresentou produção de conídios bem como crescimento micelial bastante inferiores aos demais.

A capacidade de produção de fungos em meios de cultura sólidos ou líquidos pode ser muito variável entre isolados da mesma espécie, pois além de seu potencial genético, depende das condições nas quais são cultivados. Observações realizadas entre isolados de $B$. bassiana produzidos em dois meios artificiais (Batata-Dextrose-Ágar e arroz cozido) e em cadáveres de $H$. tenuis, evidenciam estas diferenças. $\mathrm{O}$ isolado selecionado para o controle deste inseto foi aquele que apresentou alta produção em cadáveres de $H$. tenuis, alta produção em meio de cultura de arroz e alta virulência (Almeida et al., 1997). Tamai (1998) após identificar 9 isolados de B. bassiana patogênicos a T. urticae, selecionou o isolado PL63 baseando-se em sua maior capacidade de produção em arroz cozido em relação aos demais. 
Devido a importância de Hirsutella spp. como patógeno de P. oleivora, estudos iniciais avaliaram a produção deste fungo por fermentação em meio semi-sólido e submerso para a obtenção de micélio e conídios em larga escala (McCoy, 1996). Posteriormente, com o desenvolvimento do produto comercial Mycar ${ }^{\circledR}$ obtido por fermentação bifásica, aplicações em campo para o controle do ácaro da ferrugem foram realizadas, apresentando altos níveis de controle (McCoy \& Couch, 1982). Mesmo diante destes resultados, problemas relacionados a instabilidade do produto durante a estocagem, além da baixa aceitação pelo mercado, foram responsáveis pela interrupção da utilização deste fungo de maneira prática (McCoy, 1996).

Mais recentemente, a aplicação de suspensões de micélio $(50 \mathrm{~g} / \mathrm{l})$ e conídios $\left(1 \times 10^{6}\right.$ conídios/mL) para controle B. phoenicis em condições de campo, proporcionou altos índices de mortalidade da praga, inclusive superiores aos acaricidas aplicados (Acevedo \& Rosas, 2000). Apesar da possibilidade de produção do patógeno in vitro do patógeno por fermentação em meio líquido, a virulência e longevidade das estruturas submersas produzidas nestes meios podem ser inferiores às apresentadas por conídios aéreos, como foi verificado para $B$. bassiana, Metarhizium flavoviridae e inclusive $H$. thompsonii (Burges, 1998). Assim, testes de patogenicidade comparando as diversas estruturas do patógeno devem ser realizados, bem como a capacidade de produção em novos meios de cultura.

Mediante os resultados obtidos neste trabalho, o isolado selecionado foi o 1269 , pois além da patogenicidade e maior produção de conídios em meio de cultura completo, este fungo apresentou maior desenvolvimento micelial, uma característica que pode favorecer a transmissão horizontal do patógeno entre indivíduos de uma população (citar).

\subsection{Conclusões}

- As espécies B. bassiana, B. brongniartii, M. anisopliae, Verticillium spp., Sporothrix sp. e Paecilomyces spp. são pouco patogênicas para B. phoenicis; 
- Os isolados de Hirsutella spp. são patogênicos para B. phoenicis, sendo promissores para a utilização no controle desta praga;

-O isolado 1269 de Hirsutella sp. apresenta grande crescimento micelial e produção de conídios em meio de cultura completo. 


\section{CICLO BIOLÓGICO E TRANSMISSÃO HORIZONTAL DE Hirsutella sp. EM Brevipalpus phoenicis}

\section{Resumo}

Neste estudo objetivou-se observar as etapas do ciclo biológico e a transmissão horizontal de Hirsutella sp. em adultos de B. phoenicis. O ciclo biológico do fungo sobre o ácaro foi determinado avaliando-se o desenvolvimento do patógeno em diferentes períodos após sua inoculação. Utilizando-se um microscópio eletrônico de varredura realizaram-se observações após $0 ; 6 ; 12 ; 24 ; 48 ; 72$ e 120 horas da aplicação de uma suspensão de $1 \times 10^{7}$ conídios/ml de Hirsutella sp. (isolado 1269). Decorridas 0; 6; 12 e 24 horas da inoculação foram observados conídios aderidos ao tegumento do ácaro, os quais posteriormente germinaram e penetraram no corpo do hospedeiro. Os principais locais de penetração foram as bases das setas intersegmentais do histerossoma. A colonização do patógeno ocorreu a partir das 48 horas, evidenciada pela taxa de mortalidade dos indivíduos. A extrusão e conidiogênese de Hirsutella sp. foram observadas 120 horas após a inoculação, com evidências do crescimento externo de hifas e presença de conidióforos, ambos emergindo da parte posterior e anterior de $B$. phoenicis. Nos estudos de transmissão foram avaliadas duas situações: cadáveres de ácaros mortos pelo fungo misturados a ácaros vivos; ácaros vivos em contato com substrato inoculado com diferentes suspensões de Hirsutella sp. Na primeira situação os adultos vivos foram confinados em arenas de folhas de citros juntamente com os cadáveres em diferentes proporções: 100\%; 50\%; $25 \%$ e 15\%, totalizando 4 tratamentos 
além da testemunha. No segundo experimento, ácaros vivos foram transferidos para folhas de citros pulverizadas com suspensões de $1 \times 10^{5} ; 1 \times 10^{6} ; 1 \times 10^{7}$ conídios $/ \mathrm{ml}$, além de água estéril. No primeiro experimento observou-se inicialmente maior mortalidade $(23,2 \%)$ na proporção de $50 \%$, sendo ao sexto dia de observação, estatisticamente igual à proporção de $25 \%$ com $55 \%$ de mortalidade. No segundo experimento observou-se mortalidade de ácaros a partir do terceiro dia após a transferência, com $100 \%$ de mortalidade para as maiores concentrações do fungo. A transmissão horizontal de Hirsutella sp. verificada em suas situações diferentes promove mortalidade de $B$. phoenicis, podendo ser influenciada pela densidade populacional do hospedeiro e potencial de inóculo do patógeno na área.

Palavras-Chave: Transmissão horizontal; Brevipalpus phoenicis; Hirsutella sp.; Microscopia eletrônica de varredura.

\section{LIFE CYCLE AND HORIZONTAL TRANSMISSION OF Hirsutella sp. ON Brevipalpus phoenicis}

\section{Summary}

The objectives of this research were to describe some stages of the biological life cycle and the occurrence of horizontal transmission of Hirsutella sp. in adults of $B$. phoenicis. The observations of Hirsutella's life cicle on adults of the mite were done by using an electron scan microscope (SEM) at 0;6;12;24; 48; 72 and 120 hours after the aplication of $1 \times 10^{7}$ conidia/ml. The adhesion, germination and penetration of conidia through the mite ocurred at $0 ; 6 ; 12$ and 24 hours after inoculation. It was observed many spores stucked on the surface of the integument and the principal site of the penetration was the base of the intersegmental setae of histerossoma. The colonization process started at 48 hours after inoculation evidenced by adult mortality. The extrusion, 
reproduction and dissemination of Hirsutella sp. were observed $120 \mathrm{hpi}$, with evidences of the external growth of hyfae and presence of conidiophore, both emerging from the posterior and anterior sides of B. phoenicis. For the transmission bioassays two different situations were tested: cadavers mixed to live adults of $B$. phoenicis and live mites in contact to contaminated substract. In the first situation the mites were confined into arenas of citrus leaves and mixed with the cadavers in different proportions: 100\%; 50\%; $25 \%$ and $15 \%$ (4 treatments plus control). In the second bioassay, the mites were transferred to citrus leaves powdered with different suspensions of Hirsutella sp. $\left(1 \times 10^{5}\right.$; $1 \times 10^{6} ; 1 \times 10^{7}$ conidia/ml) besides sterile water. In the first bioassay, $23,2 \%$ of mortality was observed in the second porportion tested (50\%) which was estatistically equal to the third porportion (25\%) six days with $55 \%$ of mite control. In the second bioassay $100 \%$ of adult mortality was observed at third day after mite infestation on the substract with $1 \times 10^{6}$ and $1 \times 10^{7}$ conidia/ml. Thus, the horizontal transmission of Hirsutella sp. was observed in both situations promoting B. phoenicis control. The efficacy of this pathogen can be influenced by the population density of host and inoculum threshold of the pathogen in a given area.

Key-Word: Horizontal transmission; Brevipalpus phoenicis; Hirsutella sp.; Electron scan microscope. 


\subsection{Introdução}

Os fungos entomopatogênicos são microrganismos de largo espectro, capazes de infectar vários estágios de desenvolvimento de hospedeiros que habitam diferentes ambientes. Estes organismos apresentam um ciclo de vida bem definido e as variações nas relações fungo-hospedeiro são influenciadas por condições ambientais ou abióticas (temperatura, umidade, luz e radiação ultravioleta), por fatores nutricionais e pela suscetibilidade do hospedeiro (Alves, 1998).

Uma das etapas mais importantes do ciclo de vida de um patógeno, incluindo os fungos, é a dispersão de seus propágulos infectivos no ambiente após a morte do hospedeiro (Hajeck \& Leger, 1994). Os processos de produção de esporos, disseminação e capacidade de sobrevivência frente às condições adversas são aspectos tão

determinantes no desencadeamento das epizootias quanto a virulência do entomopatógeno (Alves, 1998).

A transmissão de um patógeno, ou seja, a passagem deste de uma fonte de inóculo ou de um hospedeiro infectado para outro sadio pode ser do tipo horizontal ou vertical, ocorrendo de maneira direta ou indireta com a ajuda de agentes de disseminação do ambiente. A transmissão horizontal é aquela em que o patógeno é transmitido entre indivíduos, podendo ser dependente ou não dos agentes de disseminação. Por outro lado, na transmissão vertical, o patógeno é disseminado pelos ovos de maneira hereditária (Tanada \& Kaya, 1993; Alves, 1998).

Estas características permitem que o agente de controle, uma vez liberado, mantenha ou aumente seu potencial de inóculo em uma determinada área em que esteja presente o hospedeiro. A avaliação das etapas do ciclo biológico e capacidade de transmissão do entomopatógeno entre os indivíduos de uma população é uma etapa fundamental na seleção de isolados, uma vez que o conhecimento destes aspectos determinam qual a melhor estratégia de controle a ser adotada. 


\subsection{Material e Métodos}

\subsubsection{Etapas do ciclo biológico de Hirsutella sp. sobre B. phoenicis}

Algumas etapas do desenvolvimento de Hirsutella sp. (isolado 1269) sobre adultos de B. phoenicis foram estudadas em laboratório com o auxílio de microscopia eletrônica de varrredura. Neste experimento, à semelhança do que foi realizado nos bioensaios de seleção de isolados anteriormente descritos, arenas de folhas de citros da variedade "Pêra Rio" foram utilizadas como substrato para os ácaros.

Adultos de B. phoencis provenientes da criação do laboratório foram transferidos para as folhas (15 adultos/arena foliar) e pulverizados por meio de Torre de Potter com uma suspensão contendo $10^{7}$ conídios/ml do isolado 1269 de Hirsutella sp. Após a aplicação do patógeno, as placas foram acondicionadas em caixas plásticas contendo uma folha de papel toalha umedecida no fundo e armazenadas em B.O.D. (Biological Oxygen Demand) a $26 \pm 0,5^{\circ} \mathrm{C}$ de temperatura, $70 \pm 10 \%$ de umidade relativa e 12 horas de fotofase.

Após $0 ; 6 ; 12 ; 24 ; 48 ; 72$ e 120 horas da inoculação, cada grupo de 3 placas foi retirado da câmara climatizada e armazenado em freezer a $-40^{\circ} \mathrm{C}$ para causar a morte do ácaro e a preservação do material. A preparação dos ácaros foi realizada sobre "stubs", aparatos metálicos utilizados para observações realizadas em microscópio eletrônico. Para cada placa foi preparado um "stub" correspondente, o qual continha um pedaço da folha com um número variável de ácaros.

Em seguida ao preparo das amostras, estas foram fixadas em vapor de tetróxido de ósmio $\left(\mathrm{OsO}_{4}\right)$ por 48 horas, e deixados por 72 horas em desumidificador de vidro com sílica-gel para manutenção da umidade relativa próxima a $0 \%$. Posteriormente, o material foi metalizado com ouro em Evaporador Balzers, modelo MED 010, por 120 segundos e observado em microscópio eletrônico de varredura da marca Zeiss, modelo LEO 435 VP, no NAP/MEPA (Microscopia Eletrônica Aplicada a Pesquisa Agropecuária) da ESALQ/USP. 


\subsubsection{Transmissão Horizontal de Hirsutella sp. entre adultos de B. phoenicis}

Estudou-se em laboratório aspectos da transmissão horizontal de Hirsutella sp. (isolado 1269) entre adultos de B. phoenicis em duas condições: a) cadáveres esporulados servindo de fonte de inóculo para adultos vivos; b) adultos vivos transferidos para arenas de folhas de citros contaminadas com diferentes suspensões do patógeno. Os experimentos foram realizados utilizando-se ácaros provenientes da criação do laboratório.

\subsubsection{Transmissão horizontal de Hirsutella sp. entre cadáveres e adultos vivos de B. phoenicis}

Nesta etapa foram realizados dois bioensaios. O primeiro foi um teste preliminar para comprovação da ocorrência da transmissão horizontal tendo cadáveres como fonte de inóculo, e o segundo, para avaliar este fenômeno utilizando-se diferentes proporções de adultos vivos em relação a um determinado número de mortos pelo patógeno.

Para obtenção dos cadáveres os ácaros foram transferidos para arenas de folhas de citros, confeccionadas em placas acrílicas contendo ágar solidificado, semelhante ao que foi utilizado nos bioensaios de seleção. Foram preparadas 10 arenas sendo que cada uma recebeu 40 ácaros adultos. Após a transferência dos adultos, as placas foram pulverizadas utilizando-se uma Torre de Potter (15 libras/pol ${ }^{2}$ ) com uma suspensão de $1 \times 10^{7}$ conídios/mL de Hirsutella sp. (isolado 1269). A produção do inóculo, preparação e quantificação da suspensão foram realizadas de maneira semelhante às descritas no capítulo de seleção de isolados.

As placas contendo os ácaros inoculados foram mantidas durante oito dias dentro de uma caixa acrílica com tampa forrada por uma folha de papel toalha umedecida no fundo a qual foi acondicionada em câmara climatizada $\left(26 \pm 0,5^{\circ} \mathrm{C} ; 70 \pm 10 \%\right.$ UR e 12 horas de fotofase).

Após este período, no primeiro bioensaio, cinco cadáveres apresentando sinais de esporulação foram transferidos para novas arenas de folhas de citros contendo 15 adultos 
de B. phoenicis vivos, sendo posicionados próximos ás nervuras. Para comparação, utilizou-se uma testemunha composta por 20 indivíduos vivos. Para o segundo experimento, os mortos foram misturados aos vivos de acordo com quatro tratamentos nos quais cinco cadáveres foram distribuídos aleatoriamente sobre a superfície da arena foliar e misturados às diferentes proporções de ácaros vivos $(5 ; 10 ; 20 ; 32$, correspondendo a 100\%; 50\%; $25 \%$ e 15\% de vivos). Neste ensaio, para cada tratamento, foram realizadas quatro repetições além da testemunha constituída apenas de ácaros vivos. No primeiro experimento as avaliações foram diárias e no segundo realizadas a partir do quarto dia após a transferência dos ácaros vivos até o sexto dia, anotando-se o número de mortos.

No bioensaio preliminar os resultados foram analisados comparando-se as médias (Tukey a 0,05 de probabilidade) utilizando-se o programa estatístico SANEST. No segundo bioensaio, os dados foram analisados por meio de análise de variância (p 0,06$)$ considerando-se que a proporção de ácaros mortos apresentou distribuição probabilística binomial. $\mathrm{O}$ modelo matemático utilizado foi $\log \pi / 1-\pi=\alpha+\beta \mathrm{x}+\gamma \mathrm{x}$ (programa GENMOD - SAS).

\subsubsection{Efeito residual de Hirsutella sp. para adultos de $B$. phoenicis a partir de substrato contaminado}

Para se avaliar o efeito de substrato contaminado com Hirsutella sp. na infecção de adultos de B. phoenicis, foram preparadas arenas de folhas de citros em placas acrílicas contendo ágar-água $2 \%$. Estas placas foram pulverizadas com diferentes suspensões do patógeno que constituíram os tratamentos: $1 \times 10^{5}$ conídios $/ \mathrm{ml} ; 1 \times 10^{6}$ conídios $/ \mathrm{ml} ; 1 \times 10^{7}$ conídios/ml, além de água estéril mais espalhante adesivo. A pulverização foi realizada utilizando-se uma Torre de Potter calibrada a pressão de $15 \mathrm{lb} / \mathrm{pol}^{2}$.

Em seguida, as placas foram mantidas durante alguns minutos em câmara de fluxo laminar para secagem das arenas. Para cada arena foram transferidos 20 ácaros adultos, totalizando cinco repetições por tratamento. As avaliações foram diárias observando-se a mortalidade dos ácaros até o sexto dia após a inoculação. Os resultados foram 
submetidos à análise de variância e teste de comparação de médias (Tukey a 5\% de probabilidade) utilizando-se o programa estatístico SANEST.

\subsection{RESULTADOS E DISCUSSÃO}

\subsubsection{Etapas do ciclo biológico de Hirsutella sp. sobre B. phoenicis}

Os adultos de $B$. phoenicis apresentaram em média $0,32 \mathrm{~mm}$ de comprimento e 0,12 $\mathrm{mm}$ de largura, com histerossoma reticulado e presença de cinco pares de setas marginais (Figura 6 a). Os ovos eram elípticos, medindo $0,09 \mathrm{~mm}$ de comprimento e $0,06 \mathrm{~mm}$ de largura (Figura $6 \mathrm{~b}$ ). O tegumento do adulto era bastante rugoso e aparentemente espesso, apresentando em toda sua extensão ondulações e saliências. Estas características são semelhantes às observadas por Gonzáles (1975) e Lal (1978) em outros exemplares de B. phoenicis.

Nas folhas, os ácaros encontravam-se agregados e dispostos próximos às nervuras, alojando-se em depressões e rachaduras do substrato (Figura 6 c). Esta espécie tem a preferência por locais abrigados de frutos, ramos e folhas de hospedeiros como café e citros (Chiavegato, 1986; Reis et al., 2000). Em citros, plantas com sintomas de verrugose são preferencialmente escolhidas pelo ácaro para realização da postura e desenvolvimento, especialmente das fases jovens (Reis et al., 2000). Este aspecto comportamental do ácaro pode favorecer a atuação do patógeno pois a agregação dos adultos pode propiciar um microclima adequado, aumentando a taxa de infecção e permitindo que sua disseminação por meio da transmissão horizontal seja mais rápida e eficiente devido ao maior contato entre indivíduos doentes e sadios.

Após a aplicação da suspensão conidial de Hirsutella sp. foi possível observar alguns conídios aderidos à folha de citros e também à parte dorsal do tegumento do ácaro, especialmente nas depressões laterais do propodossoma e histerossoma (Figura 7 a,b). Os conídios de Hirsutella sp. apresentavam formato esférico, medindo aproximadamente $2,3 \mu \mathrm{m}$ de diâmetro com saliências em toda sua superfície. Apesar de conídios com estas características serem considerados "típicos" de Hirsutella sp., podem 
ocorrer variações em seu padrão dentro de uma mesma espécie (Baker \& Neuzing, 1968). De acordo com Alves (1998), os conídios de Hirsutella sp. são esféricos, medem de 2 a 4 ì m de diâmetro e são cobertos por uma substância muscilaginosa. Esta, além de proteger contra a dessecação, facilita a adesão destes à superfície do hospedeiro (Alves, 1998; Van der Geest et al., 2000). A presença desta substância também foi relatada para Erynia radicans, Conidiobolus obscurus (Zygomycetes: Entomophthorales) além de Verticillium lecanii (Brey \& Latge, 1986; Wraight et al., 1990; Alves, 1998). Na etapa de adesão, o "muco" é importante para que ocorra a infecção do patógeno, uma vez que todo o processo pode ser comprometido se algum fator interferir nas interações entre os conídios e o tegumento (Hajek \& St. Leger, 1994).

Em seqüência à fase de adesão, ocorreu o início da germinação após 6 horas da inoculação de Hirsutella sp. Nesta etapa observou-se alguns conídios aderidos nas proximidades das setas marginais do histerossoma do ácaro e outros no início de germinação (Figura 8 b). A Figura 8 (a) ilustra um conídio presente no gnatossoma, aparentemente com formação de apressório. Estas estruturas são consideradas adaptações do microrganismo o qual concentra energia física e alta atividade metabólica e enzimática sobre uma pequena área do hospedeiro para tornar o processo de penetração mais eficiente (Hajek \& St. Leger, 1994). Uma vez que o tegumento de $B$. phoenicis é espesso e bastante rugoso em toda sua extensão, a formação destas estruturas durante a germinação dos conídios pode ter sido estimulada. Este processo foi comprovado para Metarhizium anisopliae infectando larvas de Manduca sexta (Lepidoptera: Sphingidae) (Leger et al., 1991). Morfologicamente, os apressórios de Hirsutella sp. parecem ser formados diretamente dos conídios, semelhante ao que foi observado em Zoophthora radicans (Zygomycetes: Entomophthorales) os quais apresentam-se como pequenos tubos germinativos (Magalhães et al., 1990).

A etapa de germinação ocorreu com maior evidência após 12 horas da inoculação. Neste tempo a maioria dos conídios de Hirsutella sp. aderidos ao tegumento do ácaro apresentavam a formação característica de tubos germinativos bem desenvolvidos os quais, provavelmente, penetraram no hospedeiro, especialmente aqueles que se encontravam próximos às setas do histerossoma (Figura 9 a,b). Estes locais destacaram- 
se como os principais sítios de penetração deste patógeno em $B$. phoenicis. No caso de insetos, as aberturas do tegumento, mais precisamente as membranas intersegmentais, são os alvos preferidos para a penetração de fungos entomopatogênicos (Alves, 1998). Com relação ao tempo e velocidade do processo germinativo, estes podem depender do isolado, condições ambientais e passado térmico do conídio, sendo que para a maioria dos deuteromicetos, em condições de laboratório, a germinação pode ocorrer, no mínimo, em 12 horas a uma temperatura de 23 a $30^{\circ} \mathrm{C}$ (Alves, 1998). A germinação de conídios de M. anisopliae, Sporothrix insectorum, V. lecanii e B. bassiana sobre Leptopharsa heveae variou entre 24 para as três primeiras espécies e 48 horas para a última (Tanzini, 2002). Para B. bassiana e M. anisopliae aplicados em adultos de Heterotermes tenuis, a germinação dos conídios ocorreu entre 12 e 48 horas e 12 e 24 horas após a inoculação, respectivamente (Moino Jr. et al., 2002).

Decorridas 24 horas da inoculação foi possível observar crescimento micelial em algumas regiões do dorso de B. phoenicis, com evidências do crescimento de hifas nas proximidades das setas das pernas anteriores (Figura 10 a). Além deste crescimento, foi possível constatar a germinação e desenvolvimento de alguns conídios de Hirsutella sp. na folha de citros em que se encontravam os ácaros (Figura 10 b). Este aspecto pode ser explicado devido à grande quantidade de reservas presentes nos conídios, associadas a estímulos proporcionados por substâncias nutritivas das folhas, as quais permitem que, em condições adversas, estes germinem na tentatativa de localizar um novo hospedeiro. Observações semelhantes foram realizadas por Tanzini et al. (2000) os quais relataram a emergência e o crescimento de hifas de $H$. thompsonii sobre folhas de seringueira a partir de cadáveres de Calacarus heveae.

Depois de 48 e 72 horas da inoculação, foi possível observar o crescimento de micélio sobre o histerossoma, além de alguns conídios germinados (Figura 11 a,b). Neste período os índices médios de mortalidade acumulada foram de $24,5 \%$ ao terceiro e $74,5 \%$ ao quarto dia da aplicação do patógeno, indicando que nesta etapa ocorreu a invasão do fungo na hemocele e os eventos que desencadearam sua morte. Estes eventos são descritos como uma combinação de danos mecânicos que ocorrem em função do crescimento do fungo, exaustão de nutrientes do hospedeiro e ação de metabólitos 
tóxicos (Hajek \& Leger, 1994). O tempo para a colonização também é variável entre 72 a 120 horas dependendo do inseto, patógeno e condições ambientais (Alves, 1998). Observações semelhantes da infecção de B. bassiana em L. heveae revelaram que a colonização deste patógeno deu-se entre 48 e 72 horas, período em que ocorreu a mortalidade de grande parte dos insetos (Tanzini, 2002).

As últimas etapas do ciclo biológico de Hirsutella sp. em B. phoenicis estão ilustradas na Figura 12 (a,b). Após 120 horas da inoculação, foi possível constatar a extrusão e conidiogênese do patógeno após a mortalidade do ácaro. Uma grande parte de hifas observadas emergindo da parte anterior (gnatossoma) e posterior (opistossoma) de B. phoenicis, provavelmente provenientes das aberturas oral, anal e/ou genital. O ácaro morto apresentava todas as pernas nitidamente enrijecidas ventralmente e aspecto "murcho" (Figura 12 a). Os conidióforos de Hirsutella sp. formados durante o processo de conidiogênese eram constituídos de uma fiálide única com aproximadamente $0,27 \mathrm{~mm}$ $(270 \mu \mathrm{m})$ na qual encontrava-se o conídio (Figura 12 b).

Uma vez fora do corpo do hospedeiro, o patógeno apresentou um crescimento intenso por todo o substrato com formação de micélio que se estendeu até $0,5 \mathrm{~mm}$ do ácaro em praticamente todas as direções. Observações semelhantes foram realizadas em cadáveres de $P$. oleivora infectados por $H$. thompsonii, verificando a presença de hifas externas com a formação de conidióforos típicos crescendo a partir do hospedeiro em todo o substrato (McCoy, 1981 citado por McCoy, 1996). Para C. heveae, as hifas e conidióforos formadas á partir dos ácaros mortos foram encontrados a uma distância até 15 vezes o comprimento deste eriofiídeo (Tanzini et al., 2000). Estas características do patógeno podem ser favoráveis para a disseminação de suas estruturas reprodutivas no ambiente, contribuindo para a transmissão horizontal da doença em um população de ácaros.

A duração de cada etapa e do ciclo de vida completo de Hirsutella sp. sobre adultos de B. phoenicis está apresentada na Figura 13. 


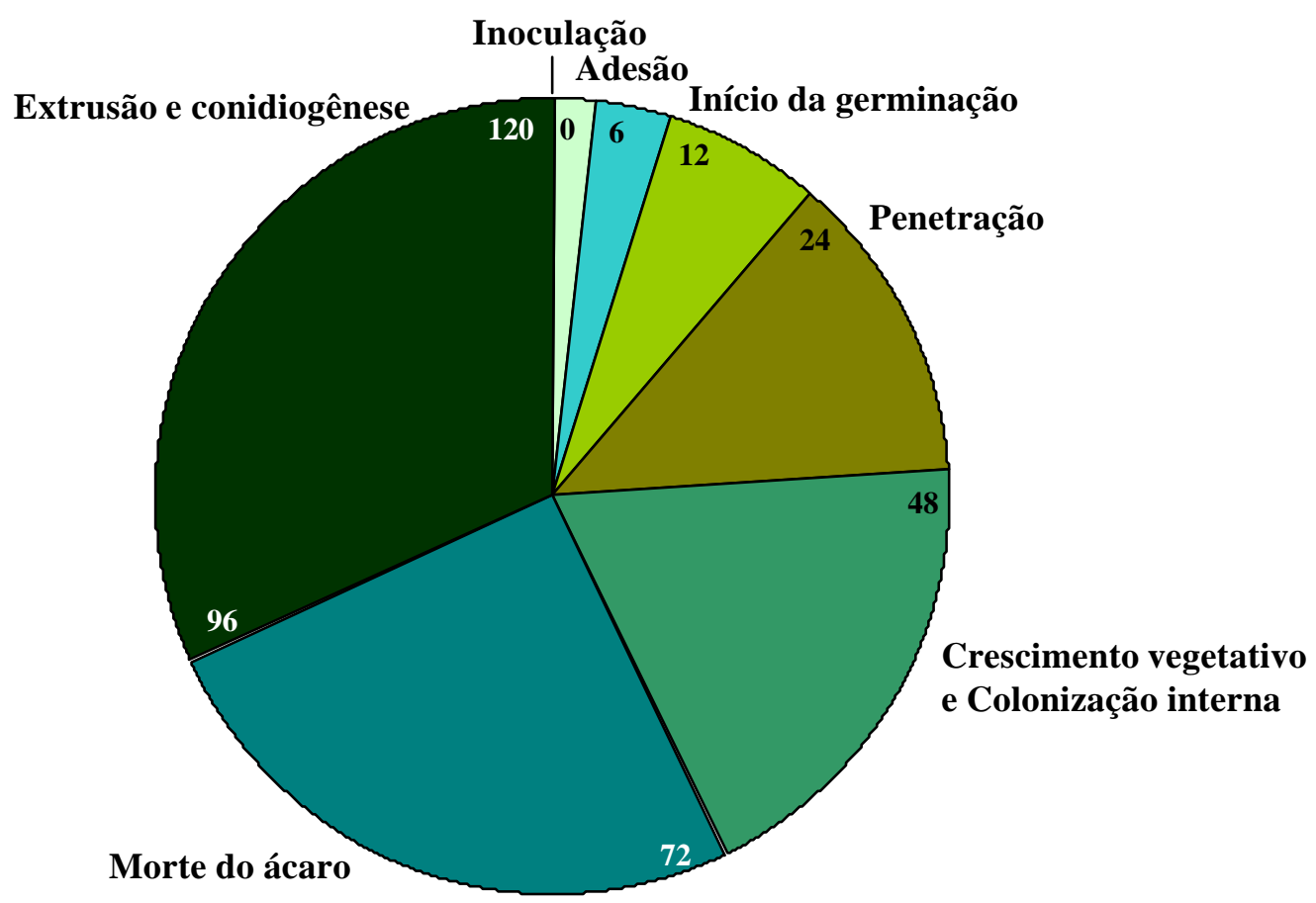

Figura 6 - Etapas do ciclo biológico de Hirsutella sp. em adultos de Brevipalpus phoenicis. 

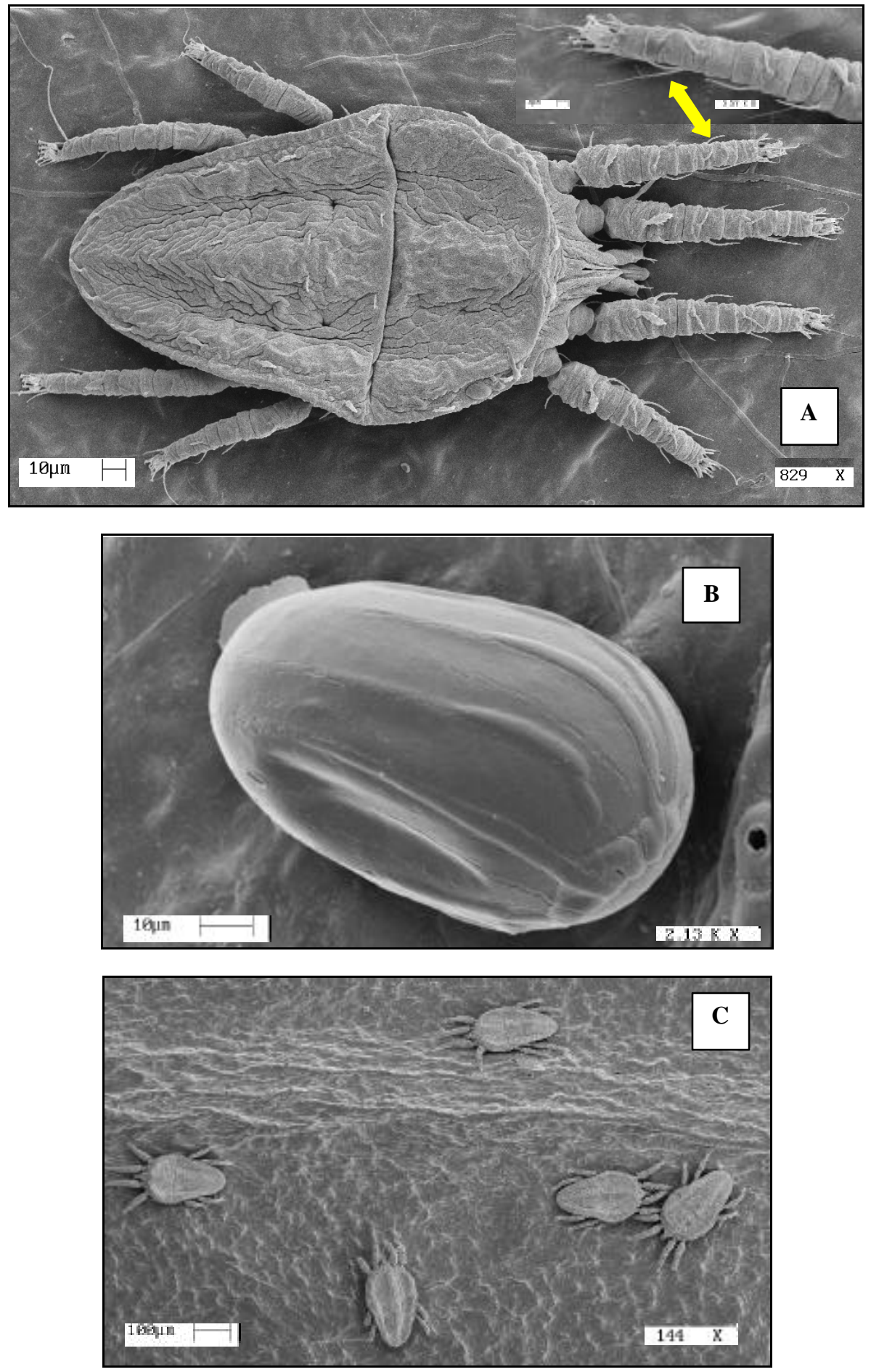

Figura 7 - Detalhes de Brevipalpus phoenicis. A) Adulto B) Detalhe do ovo C) Adultos agregados sobre a folha de citros. 

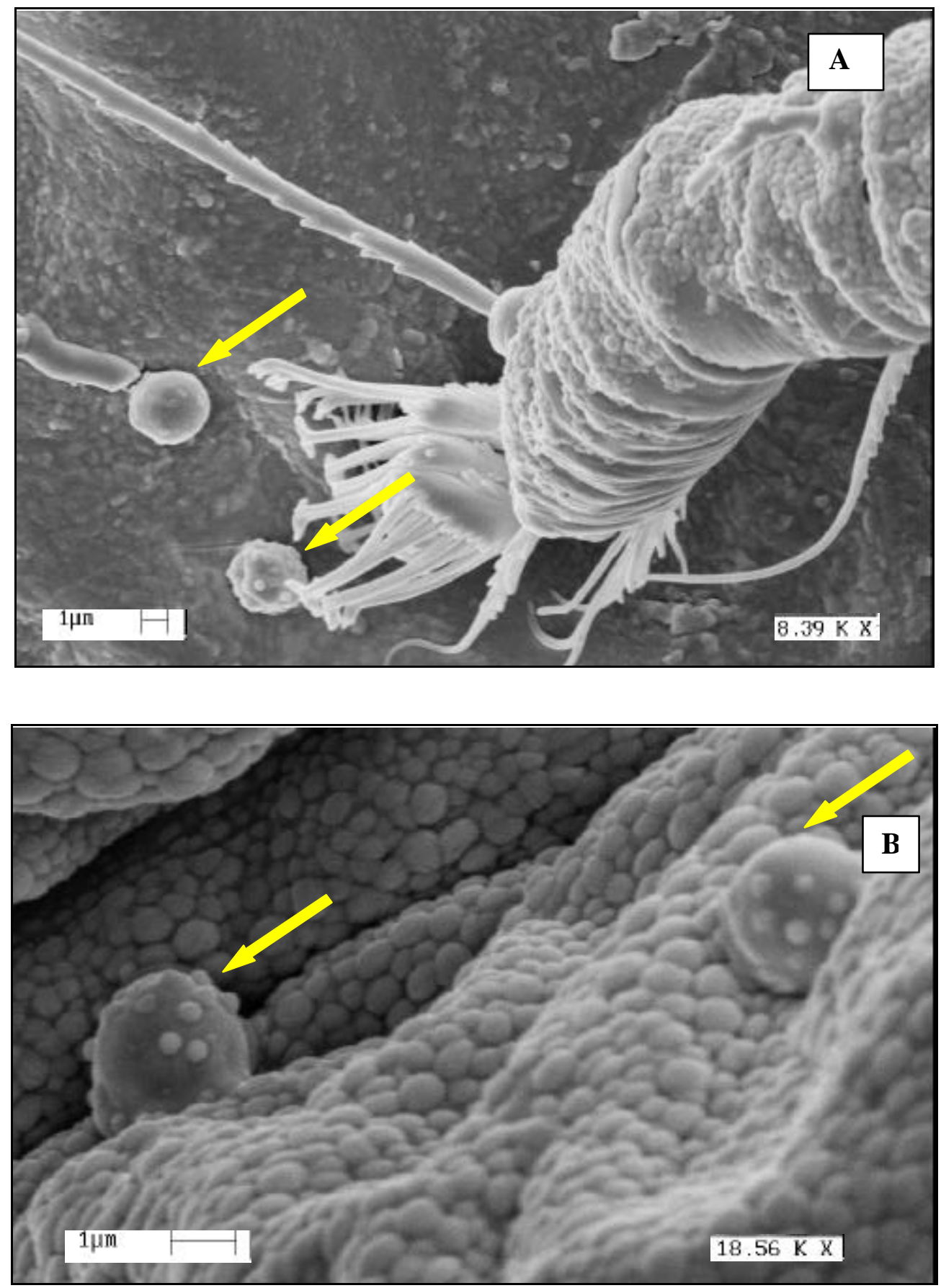

Figura 8 - Adesão de conídios de Hirsutella sp. ao corpo de Brevipalpus phoenicis (0 haa). A) Presença de conídios na folha e tarso do ácaro. B) Presença de conídios aderidos ao tegumento do ácaro. 

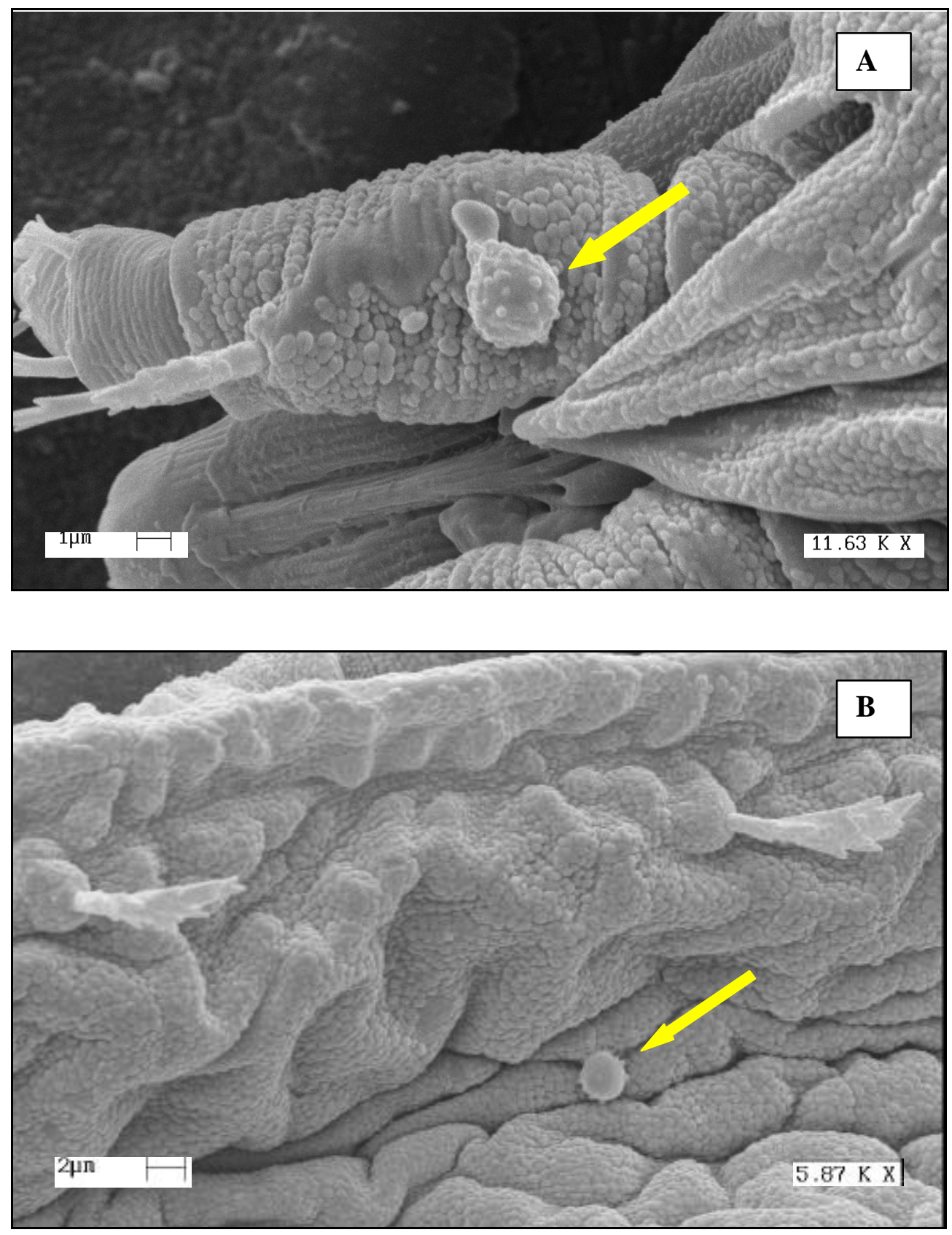

Figura 9 - Início da germinação de Hirsutella sp. sobre Brevipalpus phoenicis (6haa). A) Conídio presente no gnatossoma com aparente formação de apressório B) Conídios aderidos nas proximidades das setas marginais do histerossoma. 

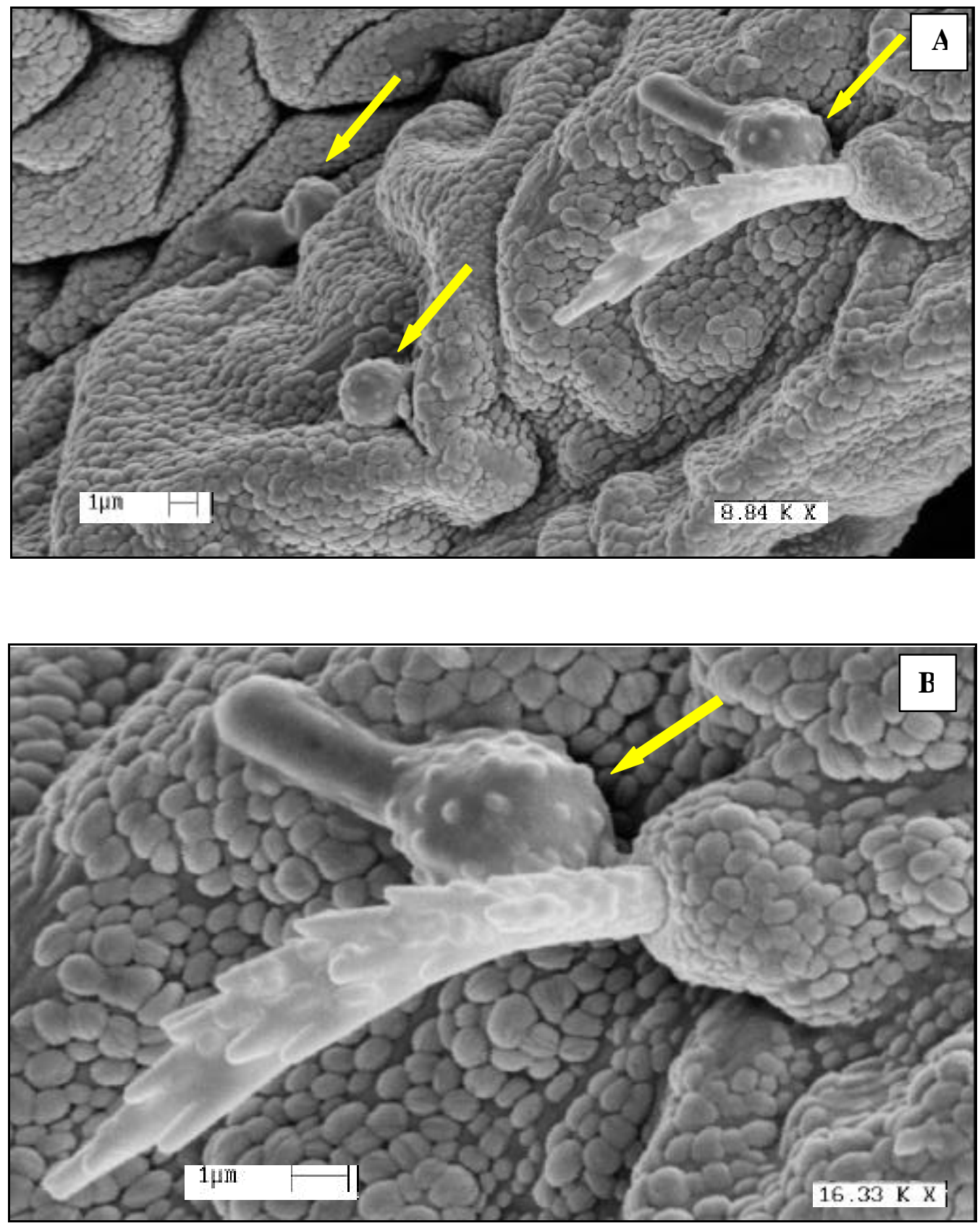

Figura 10 - Germinação de Hirsutella sp. em Brevipalpus phoenicis (12 haa). A) Conídios aderidos ao tegumento apresentando formação do tubo germinativo B) Detalhe de um conídio germinando na base de uma seta. 

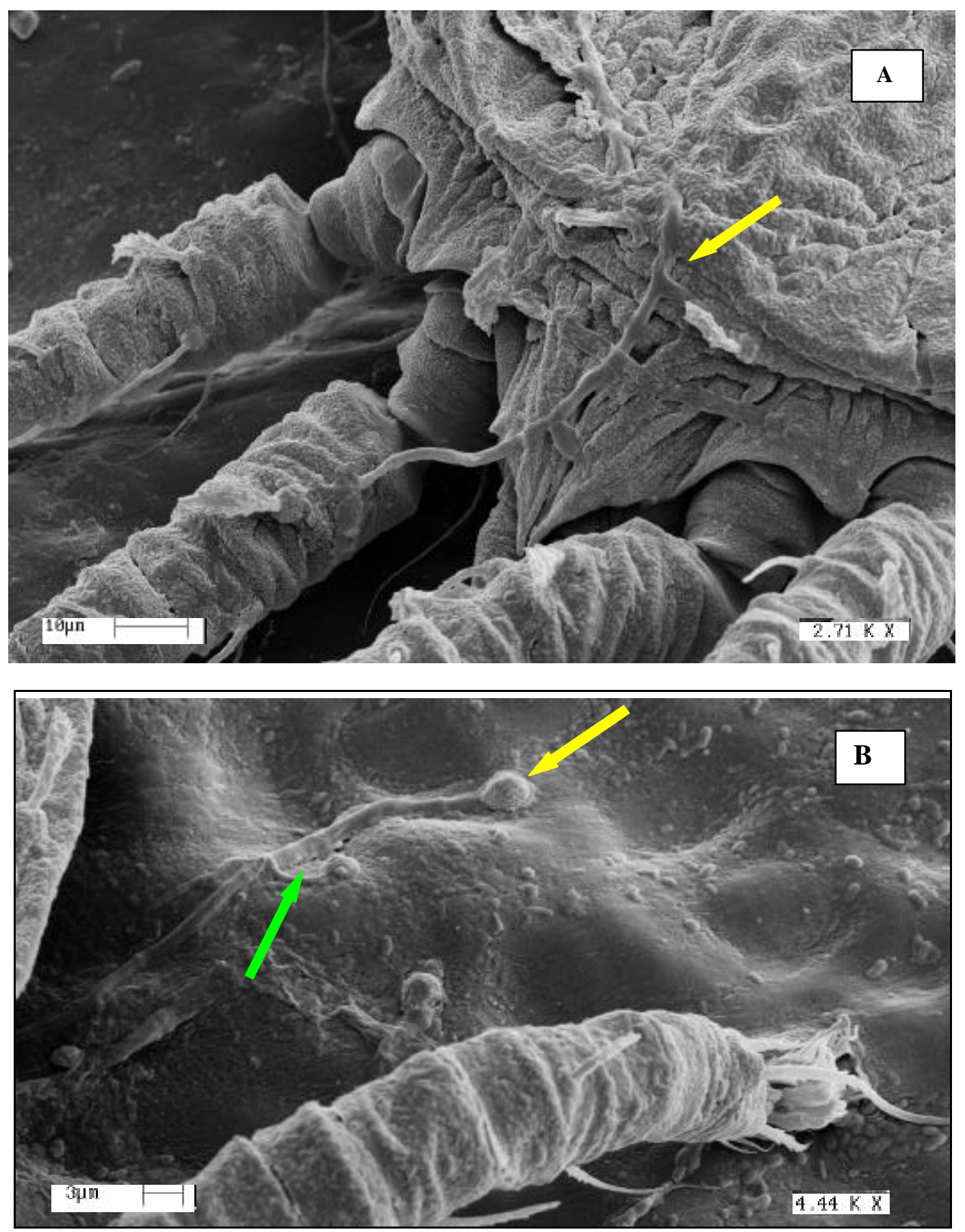

Figura 11 - A) Crescimento micelial na região dorsal de Brevipalpus phoenicis (24 haa). B) Germinação (seta amarela) e desenvolvimento de conídios (seta verde) de Hirsutella sp. na folha de citros. 

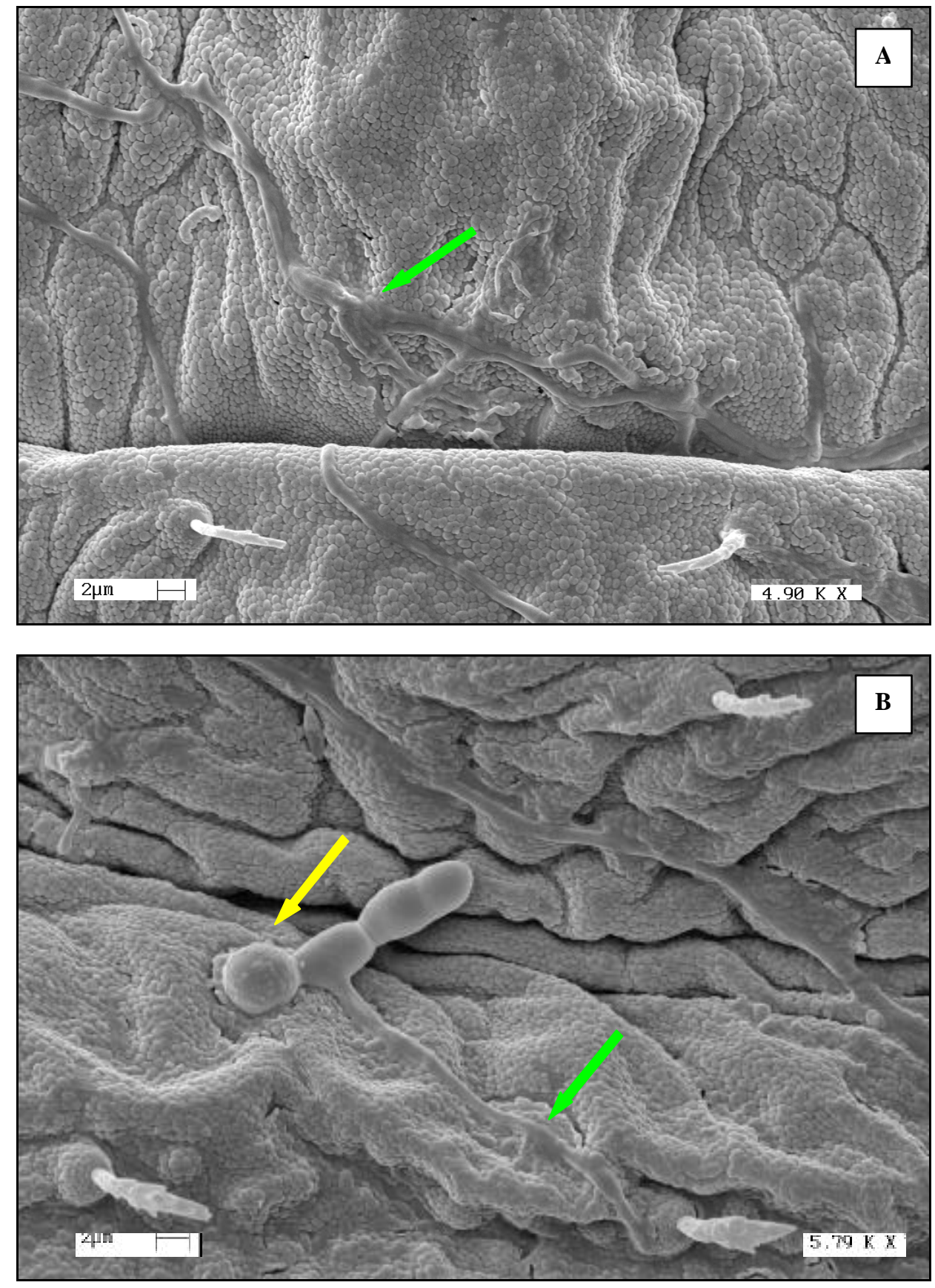

Figura 12 - Crescimento micelial de Hirsutella sp. após 48 e 72 horas da inoculação na região dorsal de Brevipalpus phoenicis. A) Micélio B) Germinação de conídio e crescimento de micélio. 

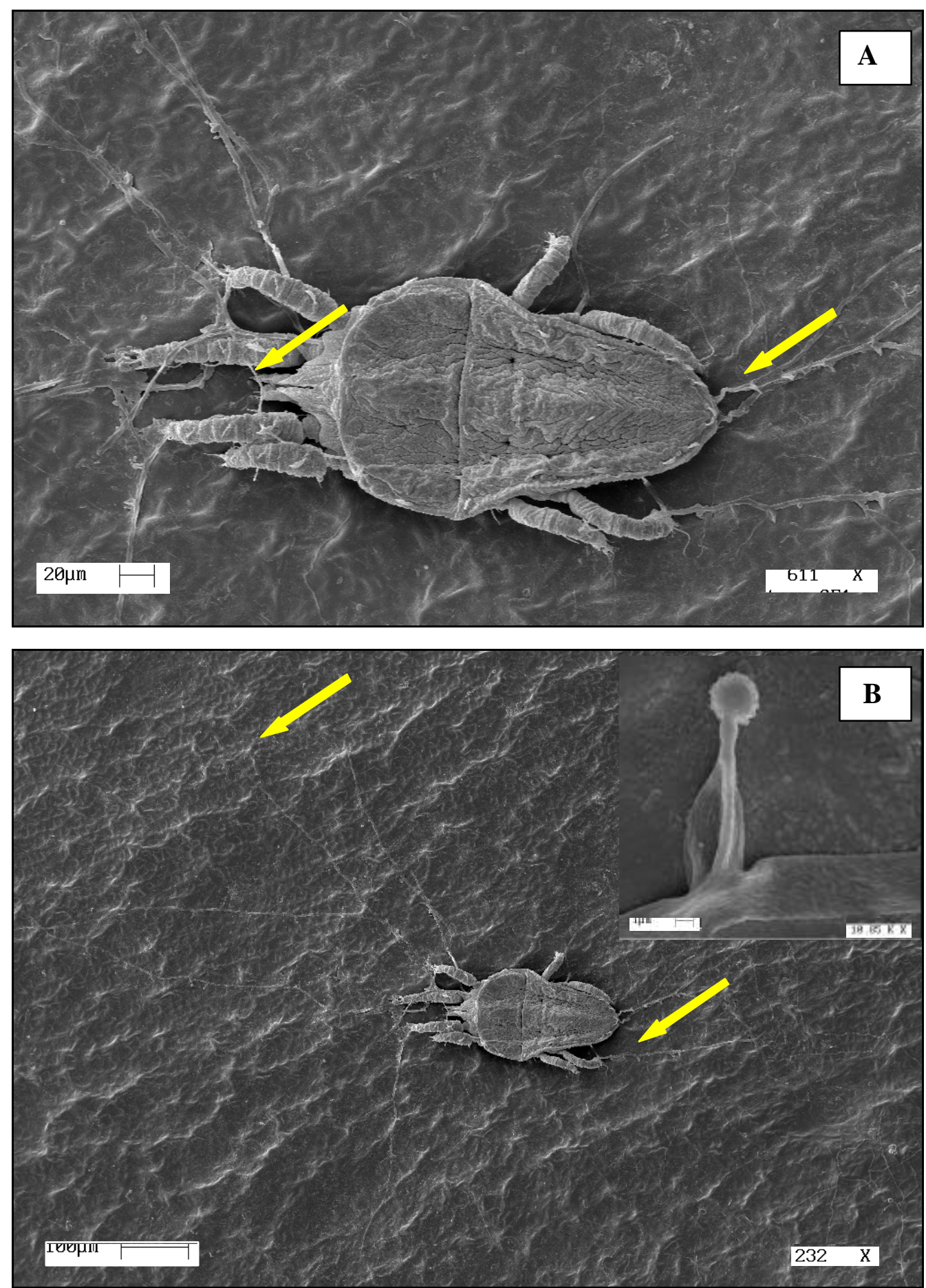

Figura 13 - Extrusão e conidiogênese de Hirsutella sp. (120 haa). A) Extrusão de hifas da parte posterior e anterior de Brevipalpus phoenicis B) Extrusão e crescimento de hifas Hirsutella sp. à longas distâncias do ácaro com detalhe do conidióforo. 


\subsubsection{Transmissão horizontal de Hirsutella sp. entre cadáveres e adultos vivos de $B$. phoenicis}

No bioensaio preliminar comprovou-se que ocorreu a transmissão horizontal de Hirsutella sp. entre cadáveres esporulados do ácaro para adultos sadios. Após cinco e seis dias da transferência dos indivíduos vivos para as placas contendo os mortos contatou-se níveis de mortalidade de $88 \%$ e $93 \%$ respectivamente, na proporção avaliada de cadáveres e ácaros vivos (Tabela 8).

Tabela 8. Mortalidade média (\%) de Brevipalpus phoenicis quando mantidos na presença de cadáveres esporulados após quatro e cinco dias.

\begin{tabular}{cccc}
\hline Tratamentos & Número de repetições & \% de mortalidade média de ácaros & \\
& & $\mathbf{5}^{\circ}$ dia & $\mathbf{6}^{\circ}$ dia \\
\hline Testemunha & 5 & 2 a A & 2 a A \\
5 mortos: $\mathbf{1 5}$ vivos & 5 & 88 b B & 93 b B \\
\hline $\begin{array}{l}\text { Médias seguidas por letras distintas diferem entre si ao nível de } 5 \% \text { e } 1 \% \text { de } \\
\text { probabilidade, respectivamente. }\end{array}$
\end{tabular}

No primeiro dia da transferência dos adultos vivos para as folhas contendo os cadáveres foi possível observar o contato direto entre muitos indivíduos e a fonte de inóculo. Ao terceiro e quarto dias muitos ácaros apresentavam sintomas de infecção pelo patógeno, fato comprovado pela elevada porcentagem de mortalidade observada a partir do quinto e sexto dias. Os altos índices de mortalidade observados para adultos de $B$. phoenicis indicam que os cadáveres de ácaros esporulados constituem uma fonte de inóculo e que podem desencadear epizootias da doença. Observações semelhantes foram realizadas para adultos de Musca domestica (Diptera: Muscidae) misturados a cadáveres desta espécie contaminados por M. anisopliae. Neste trabalho os autores concluíram que a manutenção de 50 adultos vivos do inseto em contato com 10 cadáveres proporcionou níveis variáveis de mortalidade de machos e fêmeas entre 65,3\% e 48\%, 
respectivamente, ao quinto dia de observação (Renn et al., 1999). Para Diabrotica virgifera virgifera (Coleoptera: Chrysomelidae) observou-se mortalidade superior a $80 \%$ após seis dias quando adultos vivos do inseto foram mantidos em gaiolas contendo uma média de 1,6 cadáveres do besouro por planta de milho (Mulock \& Chandler, 2001). De acordo com Furlong \& Pell (2001) a transmissão horizontal de Z. radicans e $B$. bassiana foi constatada entre machos e fêmeas adultas, adultos e larvas, e somente larvas de Plutella xylostella em diferentes situações, com destaque para a transmissão entre cadáveres esporulados e larvas não infectadas. Para T. urticae, a utilização em campo de cadáveres mortos por $N$. floridana mostrou ser uma estratégia para disseminação da doença (Van der Geest et al., 2000)

No momento da transferência a maioria dos ácaros caminhou sobre os cadáveres esporulados, muitas vezes ficando presos às hifas de Hirsutella que emergiram especialmente da parte posterior e anterior do corpo de B. phoenicis (Figura 7). Esta movimentação dos ácaros em meio aos cadáveres esporulados foi a principal forma de contato direto do hospedeiro com o patógeno, sendo provavelmente, o fator que determinou a contaminação e promoveu a mortalidade dos adultos. De acordo com Andreadis (1987) e Renn et al.(1999) a contaminação do hospedeiro pelo patógeno a partir de uma fonte de inóculo depende, entre outros aspectos, das características comportamentais dos indivíduos susceptíveis. Durante todo período de avaliação, observou-se grande quantidade de hifas crescendo a partir do corpo do ácaro por todo o substrato, evidenciando a capacidade desenvolvimento de Hirsutella em folhas de citros, aspecto que pode facilitar sua dispersão no ambiente. 


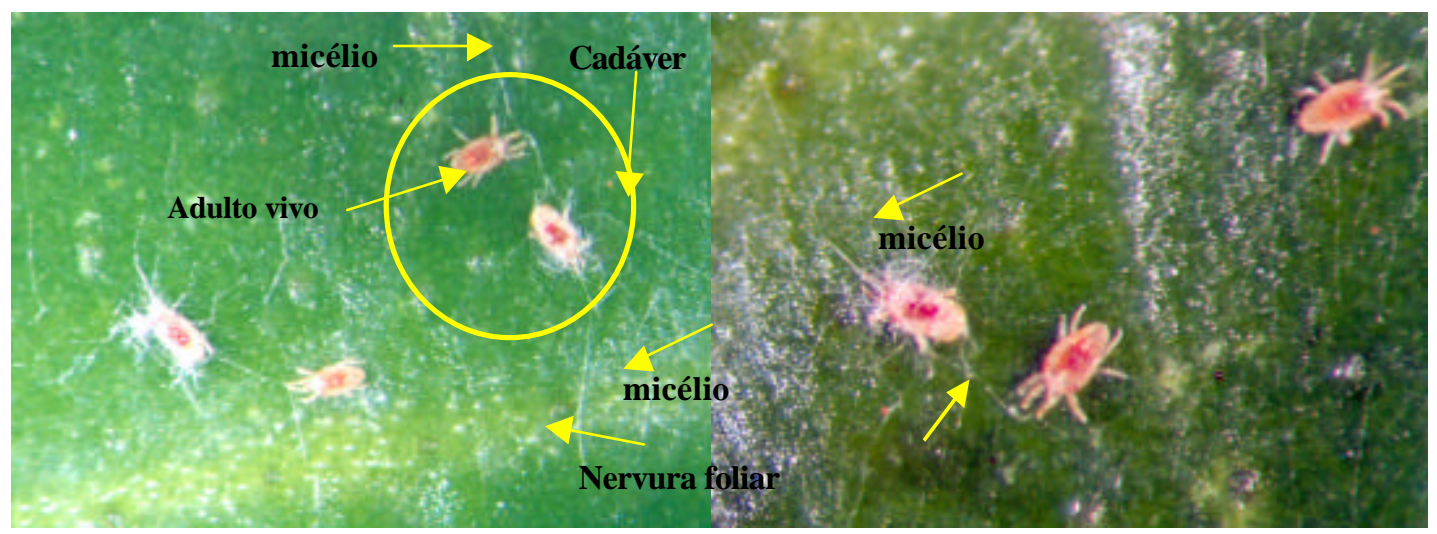

Figura 14 - Contato entre adultos vivos e cadáveres de Brevipalpus phoenicis colonizados por Hirsutella sp..

No segundo experimento observou-se que em todas as proporções ocorreu a transmissão horizontal de Hirsutella sp. (Figura 8). A maior porcentagem de mortalidade observada ao quarto e quinto dias de observação foi no tratamento em que a proporção de vivos em relação aos cadáveres foi de 50\%, ou seja, 10 indivíduos vivos para 5 mortos. Ao sexto dia, a porcentagem de mortalidade nestas condições foi estatisticamente igual ao tratamento 5/20 (25\%). Para os demais tratamentos, até o sexto dia, a porcentagem de observada mortalidade não foi superior a 30\% (Tabela 9). 


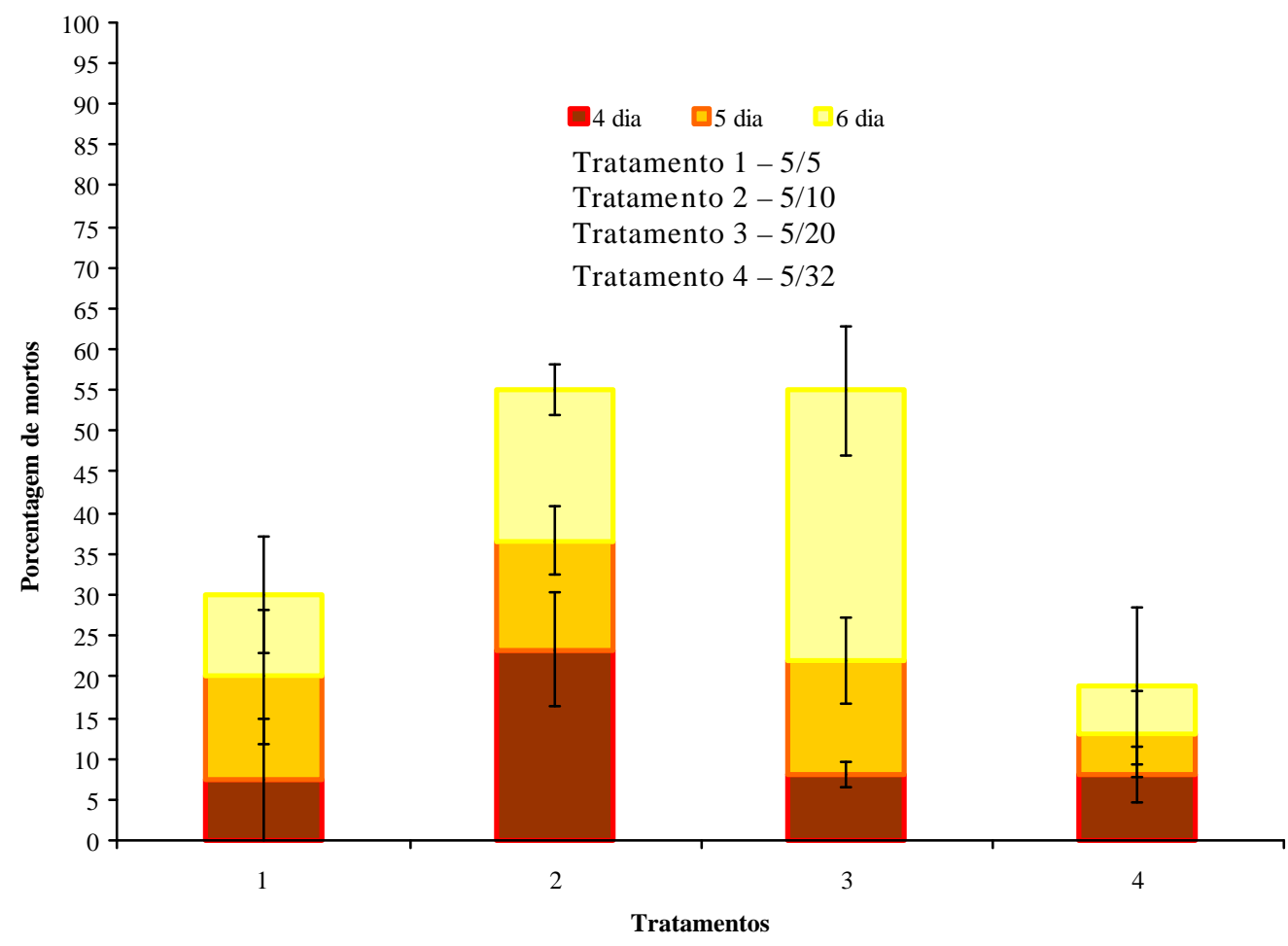

Figura 15 - Proporção média ( \pm desvio padrão) de Brevipalpus phoenicis mortos após o quarto, quinto e sexto dia de contato com cadáveres de ácaros colonizados por Hirsutella sp..

Tabela 9. Proporções médias (\%) de Brevipalpus phoenicis mortos em relação ao número de ácaros sadios misturados aos 5 cadáveres obtidas ao quarto, quinto e sexto dias após a transferência.

\begin{tabular}{cccc}
\hline Proporções & \multicolumn{3}{c}{ Dias após a transferência dos ácaros } \\
& $\mathbf{4}$ & $\mathbf{5}$ & $\mathbf{6}$ \\
\hline 5 cadáveres: 5 vivos $(100 \%)$ & $7,50 \mathrm{a}$ & $20,0 \mathrm{ab}$ & $30,0 \mathrm{~b}$ \\
5 cadáveres: 10 vivos $(50 \%)$ & $23,3 \mathrm{~b}$ & $36,67 \mathrm{a}$ & $55,0 \mathrm{ab}$ \\
5 cadáveres: 20 vivos $(25 \%)$ & $8,00 \mathrm{a}$ & $22,0 \mathrm{ab}$ & $55,0 \mathrm{ab}$ \\
5 cadáveres: 32 vivos $(15 \%)$ & $8,10 \mathrm{a}$ & $13,0 \mathrm{~b}$ & $27,0 \mathrm{c}$ \\
\hline
\end{tabular}

1 Médias seguidas por letras distintas comparadas entre os resultados das colunas diferem entre si ao nível de $6 \%$ de probabilidade. 
O desencadeamento de doenças em populações de insetos e ácaros está relacionado a fatores interdependentes como densidade e distribuição espacial do hospedeiro e do patógeno, além dos aspectos intrínsecos relacionados ao mesmo (infectividade, virulência e capacidade de sobrevivência) e condições do ambiente. $\mathrm{Na}$ transmissão horizontal o patógeno é transmitido de uma fonte de infecção para um novo hospedeiro e assim pode ser diretamente influenciado por estes fatores (Tanada \& Kaya, 1993). Para entomopatógenos que são transmitidos horizontalmente e especialmente de maneira direta como os fungos, a densidade populacional e comportamento são importantes características do hospedeiro que interferem na epizootiologia da doença (Andreadis, 1987; Hajek \& Leger, 1994; Alves, 1998). Já com relação aos patógenos a eficiência de transmissão, ou seja, a frequiência com que o hospedeiro mantém contato contato com patógeno, é o fator determinante à ocorrência da infecção (Brown \& Hasibuan, 1995).

Para B. phoenicis constatou-se que apenas entre os tratamentos 5/5 e 5/10 houve incremento da mortalidade em função do aumento do número de indivíduos sadios em relação aos cadáveres no período avaliado. Para os demais tratamentos a diminuição da relação mortos/vivos de $50 \%$ para $25 \%$ e $15 \%$ influenciou a taxa de transmissão e reduziu a mortalidade. Somente após 6 dias evidenciou-se o aumento do número de ácaros mortos nestas condições, sugerindo que o progresso da doença pode ser mais lento em função da eficiência de transmissão do patógeno quando o número de hospedeiros da população é elevado em relação ao potencial de inóculo. Estudos realizados entre operários adultos de $H$. tenuis misturados em diferentes proporções à cadáveres mortos por B. bassiana constataram que, inicialmente, a maior porcentagem de mortalidade foi observada quando a proporção vivos/mortos era $50 \%$ sendo alcançada após o quarto dia pelo tratamento no qual a proporção mortos/vivos era 33,3\% (Gusmão et al., 1999). De maneira semelhante, o aumento de indivíduos vivos em relação a cadáveres de Tetranychus urticae mortos por $N$. floridana resultou em menor proporção ácaros doentes, mesmo após 7 dias de observação (Brown \& Hasibuan, 1995).

Com relação ao comportamento do hospedeiro, uma vez que o impacto do fungo sobre altas densidades da população hospedeira depende especialmente da freqüência de 
encontros entre patógeno e hospedeiro, este aspecto pode ser uma característica determinante no sucesso da transmissão horizontal e ocorrência de epizootias. Para $B$. phoenicis, seu hábito de procurar abrigo em meio a lesões do fruto e folha, especialmente com sintomas de verrugose, muitas vezes vivendo agregados facilita o contato com a fonte de inóculo, seja outros ácaros ou mesmo insetos mortos, facilitando o processo de infecção. Para outros insetos e ácaros a influência do comportamento hospedeiro na disseminação e ocorrência de doenças fúngicas são relatados. Em experimento realizado em milho comprovou-se que para Diabrotica virgifera virgifera quando os adultos se alimentam do estilo-estigma presentes na espiga em formação, colmo e nós, existe maior contato entre besouros doentes e sadios, aumentando a taxa de transmissão de $B$. bassiana e, consequentemente, aumentando a incidência da doença (Mulock \& Chandler, 2001). Estudos de epizootiologia de Nomuraea riley constataram que para algumas espécies de lepidópteros em soja a doença foi constatada inicialmente apresentando baixa prevalência em lagartas que viviam agregadas, atingido em seqüência grandes proporções (Fuxa Jr., 1984 citado por Hajek \& Leger, 1994).

Assim, o conhecimento destes fatores durante a seleção de um entomopatógeno como possível agente de controle microbiano pode contribuir para escolha e sucesso da estratégia de controle a ser empregada, considerando-se a cultura e praga-alvo.

\subsubsection{Transmissão horizontal de Hirsutella sp. na infecção de adultos de $B$. phoenicis à partir de substrato contaminado}

Houve mortalidade significativa de $B$. phoenicis após um período de quatro dias em que estes foram mantidos em contato com substrato contaminado por Hirsutella sp., indicando que é possível ocorrer a transmissão horizontal do patógeno nestas condições (Tabela 9). Ao quarto dia da inoculação todos os indivíduos mortos apresentavam sintomas típicos de infecção por este patógeno, caracterizados pelo enrijecimento ventral das pernas e alterações na coloração do tegumento. 
Tabela 10. Análise de variância para o efeito de Hirsutella sp. (isolado 1269) na mortalidade de Brevipalpus phoenicis quando inoculada em folhas de citros.

\begin{tabular}{cccccc}
\hline Causas da Variação & G.L. & S.Q. & Q.M. & Valor F & Prob.>F \\
\hline Tratamento & 3 & 322,1552632 & 107,3850877 & 407,7915 & $0,00001^{* *}$ \\
Resíduo & 15 & 3,950000000 & 0,2633333 & & \\
Total & 18 & 326,1052632 & & & \\
\hline
\end{tabular}

** significativo a $1 \%$ de probabilidade

De acordo com Andreadis (1987) a simples permanência do hospedeiro primário em um ambiente contaminado pelo microrganismo é uma situação que permite a ocorrência da transmissão horizontal e consequentemente a epizootia. Muitos estudos de epizootiologia afirmam que a distribuição espacial do patógeno no habitat em que vive o hospedeiro é uma das condições que mais favorecem o processo de infecção e ocorrência da doença (Tanada \& Kaya, 1993).

A transmissão horizontal de $B$. bassiana entre adultos de $P$. xylostella ocorreu quando os insetos foram mantidos em contato com a superfície de placas de Petri contaminadas com diferentes concentrações do fungo. Ao quarto dia após a introdução das mariposas nos recipientes foi observada mortalidade de $100 \%$ dos indivíduos, sugerindo que a utilização em campo de armadilhas de feromônio contaminadas com fungo (Furlong \& Pell, 2001). Segundo Lacey et al. (2001) a utilização de substratos ou armadilhas atrativos contaminados com esporos de fungos promove um controle efetivo dos indivíduos atraídos além de permitir sua disseminação do patógeno no ambiente. Para populações de Mononychellus tanajoa estudos de epizootiologia comprovaram que o contato de adultos e formas jovens do ácaro com conídios de $N$. floridana (capiloconidio) presentes na superfície de folhas de mandioca promoveu a contaminação e conseqüente infecção dos mesmos, apesar de ter sido mais intensa em indivíduos com alta capacidade de mobilidade (Elliot, 1998 citado por Van der Geest et al., 2000).

A concentração das suspensões de Hirsutella sp. aplicadas influenciou diretamente na proporção de B. phoenicis mortos ao quarto dia, sendo as suspensões de $1 \times 10^{7}$ conídios $/ \mathrm{ml}$ e $1 \times 10^{6}$ conídios $/ \mathrm{ml}$ estatisticamente superiores a $1 \times 10^{5}$ conídios $/ \mathrm{ml}$ e 
testemunha. Assim, o potencial de inóculo do patógeno em contato com o hospedeiro interferiu e diminuiu o tempo de mortalidade do ácaros (Tabela 11). Na menor concentração $\left(1 \times 10^{5}\right.$ conídios/ml) observou-se apenas $4 \%$ de mortalidade de ácaros ao quarto dia da transferência, embora muitos indivíduos apresentassem sintomas da doença. Nos tratamentos em que as suspensões aplicadas foram 10 e 100 vezes menos concentradas, observou-se baixa mortalidade ao quarto dia e a presença dos indivíduos moribundos, evidências que a adesão de apenas alguns conídios ao corpo de B. phoenicis pode ser suficiente para promover o desenvolvimento da doença.

Tabela 11. Porcentagem de mortalidade média de Brevipalpus phoenicis quando mantidos em contato com substrato contaminado com as suspensões de Hirsutella sp. após o quarto dia da transferência.

\begin{tabular}{lcc}
\hline Suspensões & Número de repetições & \% de mortalidade média de ácaros ${ }^{1}$ \\
\hline $\mathbf{1 0}^{7}$ conídios/ml & 5 & $100 \mathrm{~A} \mathrm{a}$ \\
$\mathbf{1 0}^{6}$ conídios/ml & 4 & $27,5 \mathrm{~B} \mathrm{~b}$ \\
$\mathbf{1 0}^{\mathbf{5}}$ conídios/ml & 5 & $4,0 \mathrm{C} \mathrm{c}$ \\
Testemunha & 5 & $0,0 \mathrm{C} \mathrm{c}$ \\
\hline
\end{tabular}

Médias seguidas por letras distintas diferem entre si ao nível de $5 \%$ e $1 \%$ de probabilidade, respectivamente.

A influência do potencial de inóculo do fungo na transmissão horizontal têm sido descritos na literatura para alguns casos. O contato de adultos de $M$. tanajoa com 1; 2 ;4; 6; 8 capiloconidios de $N$. floridana promoveu variações entre 88 a $100 \%$ na mortalidade dos ácaros. Consequentemente observou-se redução no tempo de morte dos ácaros que estiveram em contato com maior número de estruturas do patógeno (Oduor et al., 1997). De maneira semelhante, para larvas $P$. xylostella expostas durante $0 ; 1 ; 10 ; 30 ; 90$ e 270 segundos a $6,2 \mu \mathrm{g} / \mathrm{mm}^{2} ; 2,4 \mu \mathrm{g} / \mathrm{mm}^{2}$ e $0,24 \mu \mathrm{g} / \mathrm{mm}^{2}$ de $B$. bassiana obtiveram ao terceiro dia de observação mortalidades de 100\%; $97 \%$ e 43\%, respectivamente, para o maior tempo de inoculação (Furlong \& Pell, 2001). 
Em situações de campo, a capacidade de dispersão de Hirsutella sp. na cultura de citros foi demonstrada para algumas pragas com resultados significativos de controle. Para B. phoenicis e Brevipalpus obovatus além de H. thompsonii ter promovido controle eficiente com redução de sintomas de leprose em frutos, contatou-se a presença de cadáveres infectados durante um período de sete meses após a aplicação, inclusive no tratamento controle (Acevedo \& Rosas, 2000). Este fato já havia sido verificado anteriormente para $P$. oleivora em que após a aplicação do produto comercial Mycar ${ }^{\circledR}$ foram observados ácaros com sintomas de infecção em todo o pomar, inclusive áreas não tratadas (McCoy \& Couch, 1982).

Assim, considerando-se o potencial de dispersão de Hirsutella sp., algumas considerações podem ser feitas à respeito de sua utilização prática para controle de $B$. phoenicis em pomares cítricos, levando-se em conta características da cultura para determinar a estratégia de controle mais adequada.

De acordo com Alves (1998) para culturas perenes com produção em grandes áreas como é o caso de citros, a introdução inoculativa do patógeno em áreas que não ocorra ou sua incrementação são estratégias mais viáveis. Para os dois casos, após a liberação do patógeno em campo sua densidade deve aumentar com o tempo à medida em que ocorre a transmissão horizontal da doença na população hospedeira. Segundo Hajek \& Leger (1994) a eficiência destas estratégias já foi verificada para 19 diferentes patógenos e hospedeiros em mais de 26 localidades. Em citros, o controle de P. oleivora com H. thompsonii, aleirodídeos com Aschersonya aleyrodes e algumas espécies de cochonilhas por fungos telomórficos mediante a introdução inoculativa ou incremento dos patógenos são exemplos da eficiência destas estratégias (Alves, 1998).

A ocorrência de transmissão horizontal do fungo no pomar é uma condição essencial para que estas estratégias propostas sejam bem sucedidas e a vegetação é um fator que influencia a prevalência da doença no caso de interações tritróficas (plantapatógeno-hospedeiro) (Hajek \& Leger, 1994).A possibilidade de haver interação entre entomopatógenos e plantas, em que estas são beneficiadas a medida que estimulam o contato entre o hospedeiro e o patógeno, tem sido muito explorada pela literatura, em alguns casos, com evidências de interação mutualística (Elliot et al., 2000). 
Simultaneamente a introdução ou incrementação de Hirsutella em pomares, uma estratégia que pode ser feita é a conservação ou proteção do entomopatógeno, realizada pela simples utilização de produtos químicos seletivos e compatíveis (Alves et al., 2000). O efeito sinérgico que pode ser obtido entre a ação conjunta do produto químico e do fungo é uma prática que pode tornar o controle mais efetivo, além de reduzir impacto ambiental.

\subsection{Conclusões}

- O ciclo biológico de Hirsutella sp. em adultos de B. phoenicis inicia-se entre 0 e 6 horas da inoculação com a etapa de adesão, seguida da germinação e penetração dos conídios no corpo do ácaro (12 a 48 horas), colonização interna (48 a 96 horas) e finaliza-se após 120 horas com a extrusão e conidiogênese do patógeno.

- Ocorre a transmissão horizontal de Hirsutella a partir de cadáveres esporulados de $B$. phoenicis.

- A aplicação de suspensões de Hirsutella sp. em folhas de citros causa altos níveis de mortalidade de adultos de B. phoenicis.

- A densidade de hospedeiros vivos em relação aos indivíduos mortos bem como a quantidade de inóculo presente no susbtrato influenciam a taxa de mortalidade. 


\section{CONCLUSÕES GERAIS}

- os isolados 1221; 1269; 1282 e 1266 de Hirsutella sp. são patogênicos e promissores ao controle de Brevipalpus phoenicis

- em meio de cultura sólido (M.C.) o isolado 1269 apresenta maior crescimento vegetativo e esporulação em relação aos isolados 1221; 1282 e 1266.

- O tempo de duração e etapas do ciclo biológico de Hirsutella sp. em adultos de $B$. phoenicis são: adesão (0 a 6 horas); início da germinação (12 a 24 horas); penetração (24 a 48 horas); crescimento vegetativo e colonização interna (48-72 horas); morte do ácaro (72 a 96 horas); extrusão e conidiogênese (96-120 horas).

- Ocorre transmissão horizontal de Hirsutella sp. a partir de cadáveres e susbtrato contaminado para adultos sadios de B. phoenicis. 


\section{REFERÊNCIAS BIBLIOGRÁFICAS}

ABBOTT, W.S. A method of computing the effectiveness of na insecticide. Journal of Economic Entomology, v.18, p.265-267, 1925.

ACEVEDO, J.L.R.; ROSAS, L.S. Control biológico de Brevipalpus spp. en Citrus aurantifolia en Guerrero, México. Manejo Integrado de Plagas (Costa Rica), v.55, p.56-59, 2000.

ALMEIDA, J.E.M.; ALVES, S.B.; PEREIRA, R.M. Selection of Beauveria spp. isolates for control of the termite Heterotermes tenuis (Hagen, 1858). Journal of Applied Entomology, v.121, p.539-543, 1997.

ALVES, E.B. Manejo da resistência do ácaro da leprose Brevipalpus phoenicis (Geijskes, 1939) (Acari: Tenuipalpidae) ao acaricida dicofol. Piracicaba, 1999. 91p. Dissertação (Mestrado) - Escola Superior de Agricultura "Luiz de Queiroz", Universidade de São Paulo.

ALVES, E.B.; OMOTO, C.; FRANCO, C.R. Bases for an acaricide resistance management program of Brevipalpus phoenicis (Acari: Tenuipalpidae) to the acaricide dicofol in brazilian citrus. In: INTERNATIONAL CONGRESS OF ENTOMOLOGY, 21., Foz do Iguaçú, 2000. Abstracts. Londrina: EMBRAPA, CNPSo, 2000. Book 1, p.4. 
ALVES, E.B., RIBEIRO, P.C.; CAMPOS, F.J.; OMOTO, C. A resistência do ácaro da leprose (Brevipalpus phoenicis) ao dicofol pode ser manejada? In: CONGRESSO BRASILEIRO DE ENTOMOLOGIA, 17., Rio de Janeiro, 1998. Resumos. Rio de Janeiro: SEB, 1998. v.2, p.1048.

ALVES, S.B. Fungos entomopatogênicos: In: ALVES, S.B. (Ed.) Controle microbiano de insetos. São Paulo: Manole, 1986. cap.6, p.73-126.

ALVES, S.B. Fungos entomopatogênicos. In: ALVES, S.B. (Ed.) Controle microbiano de insetos. 2.ed. Piracicaba: FEALQ, 1998. cap. 11, p.289-381.

ALVES, S.B.; LECUONA, R.E. Epizootiologia aplicada ao controle microbiano de insetos. In: ALVES, S.B. (Ed.) Controle microbiano de insetos. Piracicaba: FEALQ, 1998. cap. 5, p.289-381.1998.

ALVES, S.B.; PEREIRA, R.M. Produção de fungos entomopatogênicos. In: ALVES, S.B. (Ed.) Controle microbiano de insetos. Piracicaba: FEALQ, 1998. cap. 27, p.845-867.

ALVES, S.B.; LOPES, R.B.; TAMAI, M.A.; MOINO JUNIOR, A.; ALVES, L.F.A. Compatibilidade de produtos fitossanitários com entomopatógenos em citros. Laranja, v.21, n.2, p.295-306, 2000.

ANDREADIS, T.G. Key factors: transmission. In: FUXA, J.R.; TANADA, Y. (Ed.) Epizootiology of insect diseases. New York: John Wiley, 1987. cap.6, p.159-176.

ARASHIRO, F.Y.; RAIZER, A.J.; SUGAHARA, C.A.; MOTA, R.; SILVA, J.M.; MARICONI, F.A.M. Novo ensaio de combate químico ao ácaro da leprose dos citros Brevipalpus phoenicis (Geijskes, 1939) em laranjeiras. Anais da Escola Superior de Agricultura Luiz de Queiroz, v. 45, n. 1, p.67-78, 1988. 
BAKER, J.R.; NEUNZIG, H.H. Hirsutella thompsonii as a fungus parasite of the blueberry bud mite. Journal of Economic Entomology, v.61, n.4, p.1117-1118, 1968.

BEARVERS, J.B.; REED, D.K. Susceptibility of seven tetranychids to the nonoccluded virus of the citrus red mite and the correlation of the carmine spider mite as a vector. Journal of Invertebrate Pathology, v.20, p. 279-283, 1972.

BOARETTO, M.A.C.; CHIAVEGATO, L.G.; SILVA, C.A.D. da Transmissão da leprose através de fêmeas de Brevipalpus phoenicis (Geijskes, 1939) (Acari: Tenuipalpidae) e de seus descendentes, em condições de laboratório. Científica, v.21, n.2, p.245-253, 1993.

BREY, P.T.; LATGE, J.P. Integumental penetration of the pea aphid, Acyrthosiphon pisum, by Conidiobolus obscurus (Entomophthoraceae). Journal of Invertebrate Pathology, v.48, p.34-41, 1986.

BROW, G.C.; HASIBUAN, R. Conidial discharge and transmission efficiency of Neozygites floridana, na entomopathogenic fungus infecting two-spotted spider mites under laboratory conditions. Journal of Invertebrate Pathology, v.65, p.10$16,1995$.

BURGES, H.D. Formulation of mycoinsecticides. In: BURGES, H.D. (Ed.) Formulation of microbial biopesticides: beneficial microrganisms, nematodes and seed treatments. London: Kluwer Academic, 1998. cap. 4, p.132-185.

CHIARADIA, L.A.; SOUZA, L.C. de; MILANEZ, J. M. Fluctuation of Brevipalpus phoenicis (Acari: Tenuipalpidae) en citric orchard in Chapecó, SC.. In: INTERNATIONAL CONGRESS OF ENTOMOLOGY, 21., Foz do Iguaçú, 2000. Abstracts. Londrina: EMBRAPA, CNPSo, 2000. Book 1, p.17. 
CHIAVEGATO, L.G. Acarologia: aspectos biológicos. In: PARRA, J.R. (Ed.) Biologia dos insetos. Piracicaba: ESALQ, 1979. p.282-294.

CHIAVEGATO, L.G. Biologia do ácaro Brevipalpus phoenicis em citros. Pesquisa Agropecuária Brasileira, v. 21, n.8, p.815-816, 1986.

CHIAVEGATO, L.G. Avaliação da potencialidade de Brevipalpus phoenicis (Geijskes, 1939) (Acari: Tenuipalpidae) na transmissão da leprose em plantas cítricas. In: CONGRESSO BRASILEIRO DE ENTOMOLOGIA, 15., Caxambú, 1995. Abstracts. Caxambú: SEB, 1995. p.14.

CHIAVEGATO, L.G.; KHARFAN, P.R. Comportamento do ácaro da leprose Brevipalpus phoenicis (G.) (Acari: Tenuipalpidae) em citros. Anais da Sociedade Entomológica do Brasil, v.22, p. 355-359, 1993.

CHIAVEGATO, L.G.; MISCHAN, M.M. Comportamento do ácaro Brevipalpus phoenicis (Geijskes, 1939) (Acari: Tenuipalpidae) em frutos de diferentes variedades cítricas. Científica, v.15, n.1/2. p.17-22, 1987.

CHIAVEGATO, L.G.; MISCHAN, M.M.; SILVA, M. A. Prejuízos e transmissibilidade de sintomas de leprose pelo ácaro Brevipalpus phoenicis (Geijskes, 1939) Sayed, 1946 (Acari, Tenuipalpidae) em citros. Científica, v.10, n.2. p265-271, 1982.

CHIAVEGATO, L.G.; TRINDADE, M.L.B.; NOGUEIRA, C.E.T.; AFFÉRRI, F.S. Efeito de espalhante adesivo na eficiência de hexytiazox no controle do ácaro Brevipalpus phoenicis G. (Acari: Tenuipalpidae) em citros. Anais da Sociedade Entomológica do Brasil, v.22, n.2, p.341-348, 1993. 
CHIAVEGATO, L.G.; NOGUEIRA, C.E.T.; AFFÉRRI, F.S.; RANDO, J.S.S; LIMA,

S.L.L. Efeito da lavagem artificial na eficiência de acaricidas-ovicidas no controle de Brevipalpus phoenicis (Geijskes, 1939) (Acari: Tenuipalpidae) em citros. Pesquisa Agropecuária Brasileira, v.29, n.1, p.1-5, 1994.

CHILDERS, C.C. Feeding injury to "Robinson" tangerine leaves by Brevipalpus mites (Acari: Tenuipalpidae) in Florida and evaluation of chemical control on citrus. Florida Entomologist, v.77, n.2, p.265-271, 1994.

CHILDERS, C.C.; KITAJIMA, E.W.; WELBOURN, W.C.; RIVERA, C.; OCHOA, R. Brevipalpus como vectores de la leprosis de los cítricos. Manejo Integrado de Plagas, v.60, p.61-65, 2001a.

CHILDERS, C.C.; RODRIGUES, J.C.; KITAJIMA, E.W., DERRICK, K.S., RIVERA, C., WELBOURN, W.C. Estratégia de manejo para romper el ciclo del vector Brevipalpus spp. - Rhabdovirus, causante de la leprosis de los cítricos. Manejo Integrado de Plagas, v.60, p.71-75, 2001 b.

CORREIA, A.C.B.; GRAVENA, S.; KREBKSY, E.O. Primeira citação do fungo Hirsutella thompsonii var. thompsonii parasitando Phyllocoptruta oleivora (Ashm.) (Acari, Eriophyidae) no Brasil. Laranja, v.13, n.2, p.553-558, 1992.

COSTA JÚNIOR, W. H.; LOPES, R.B. Fruticultura orgânica: alternativa de diferenciação. In: FNP CONSULTORIA \& COMÉRCIO. Agrianual 2000: anuário da agricultura brasileira. Saõ Paulo, 2000. p. 62.

DOMINGUEZ, F.S.; BERNAL, A.; CHILDERS, C.C.; KITAJIMA, E.W. First report of the citrus leprosis virus in Panama. Plant Disease, v.85, n.2, p.288, 2001. 
ELLIOT, S.L.; SABELIS, M.W.; JANSSEN, A.; VAN DER GEEST, L.P.S.; BEERLING, E.A.M.; FRASEN, J. Can plants use entomopathogens as bodyguards? Ecology Letters, v.3, p.228-235, 2000.

EVANS, G.A.; CROMROY, H.A.; OCHOA, R. The Tenuipalpidae of Honduras (Tenuipalpidae: Acari). Florida Entomologist, v.76, p.126-155, 1993.

FISHER, F.E. An Entomophthora attacking citrus red mite. Florida Entomologist, v.34, n.3, p.83-88, 1951.

FNP CONSULTORIA \& COMERCIO. Agrianual 2000: anuário da agricultura brasileira. São Paulo, 2000. 346p.

FURLONG, M.; PELL, J.K. Horizontal transmission of entomopathogenic fungi by the diamondback moth. Biological Control, v.22, p. 288-299, 2001.

GEORGHIOU, G.P.; TAYLOR, C.E. Genetic and biological influences in the evolution of insecticide resistance. Journal of Economic Entomology, v.70, p. 653-658, 1977.

GILMORE, J.E. Preliminary field evaluation of a noninclusion virus for control of the citrus red mite. Journal of Economic Entomology, v.58, n.6, p.1136-1140, 1965.

GILMORE, J.E.; TASHIRO, H. Fecundity, longevity and transinfectivity of citrus red mites (Panonychus citri) infected with a noninclusion virus. Journal of Invertebrate Pathology, v.8, p.334-339, 1966. 
GONZÁLES, R.H. Revision of the Brevipalpus phoenicis "complex" with descriptions of new species from Chile and Tailand (Acarina, Tenuipalpidae). Acarologia, v.17, n.1, p.81-91, 1975 .

GRAVENA S. Manejo ecológico de pragas no pomar cítrico. Laranja, v.11, n.1, p.205-225, 1990.

GRAVENA, S. Manejo ecológico de pragas dos citros: Aspectos práticos. Laranja, v.19, n.1, p.61-77, 1998.

GUIRADO, N.; SILVÉRIO, J.L. Leprose e declínio: problemas sérios da citricultura paulista. Laranja, v.13, n.2, p.541-552, 1992.

GUSMÃO, L.G.; CASTIGLIONI, E.A.; ALVES, S.B. Diseminacion de Beauveria bassiana entre Heterotermes tenuis. Manejo Integrado de Plagas, v.52, p.89-92, 1999.

HAJEK, A.E.; LEGER, R.J. Interations between fungal pathogens and insect hosts. Annual Review of Entomology, v.39, p.293-322, 1994.

HARAMOTO, F. H. Biology and control of Brevipalpus phoenicis (Geijskes) (Acarina: Tenuipalpidae). Technical Bulletin of Hawaii Agricultural Experiment Station n.68, p.6-61, 1969.

HELlE, W; BOLlAND, H.R.; HEITMANS, W.R.B. Chromosomes and types of parthenogenesis in the fase spider mites (Acari: Tenuipalpidae). Genetica, v.54, p.45-50, 1980.

JEPPSON, L.R.; KEIFER, H.H.; BAKER, E.W. Mites injurious to economic plants. Berkeley: University of California Press, 1975. 614p. 
KENETH, R.; MUTTATH, T.I.; GERSON, U. Hirsutella thompsonii, a fungal pathogen of mites. I. Biology of the fungus in vitro. Annals of Applied Biology, v.91, n.1, p.21-28, 1979.

KITAJIMA, E.W.; REZENDE, J.A.M.; RODRIGUES, J.C.V.; CHIAVEGATO, L.G., PIZA JR, C.T.; MOROZINI, W. Green spot of passion fruit, a possible viral disease associated with infestation by the mite Brevipalpus phoenicis Fitopatologia Brasileira, v.22, n.4, p.555-559, 1997.

KNORR, L.C.; DENMARK, H.A.; BURNETT, H.C. Ocurrence of Brevipalpus mites, leprosis and flase leprosis on citrus in Florida. Florida Entomologist, v.51, p.11$17,1968$.

LACEY, L.A.; FRUTOS, R.; KAYA, H.K.; VAILS, P. Insect pathogens as biological control agents: do they have a future? Biological Control, v.21, p. 230-248, 2001.

LAL, L. Biology of Brevipalpus phoenicis (Geijskes) (Tenuipalpidae: Acarina). Acarologia, v.20, n.1, p.97-101, 1978.

LEGER, R.J.; GOETTEL, M.; ROBERTS, D.W.; STAPLES, R.C. Penetrations events during infection of host cuticle by Metarhizium anisopliae. Journal of Invertebrate Pathology, v.58, p.168-179, 1991.

LIPA, J.J. Microbial controle of mites and ticks In: BURGES, H.D.; HUSSEY, N.W. (Ed.) Microbial control os insects and mites. London: Academic Press, 1971. cap.15, p.357-373.

LIU, J.C.; BOUCIAS, D.G.; PENDLAND, J.C.; LIU, W.Z.; MARUNIAK, J. The mode of action of hirsutellin A on eukaryotic cells. Journal of Invertebrate Pathology, v.67, p.224-228, 1996. 
LOPES, R.B. Seleção de fungos entomopatogênicos e controle de Frankliniella occidentalis. (Tysanoptera: Thripidae). Piracicaba, 1999. 72p. Dissertação (Mestrado) - Escola Superior de Agricultura "Luiz de Queiroz", Universidade de São Paulo.

MAGALHÃES, B.P.; BUTT, T.M.; HUMBER, R.A.; SHIELDS, E.J.; ROBERTS, D.W. Formation of apressoria in vitro by the entomopathogenic fungus Zoophthora radicans (Zygomycetes: Entomophthorales). Journal of Invertebrate Pathology, v.55, p.284-288, 1990.

MARICONI, F.A.M.; RANGEL, R.C.; HAMAMURA, R.; CLARI, A.I.; MESQUITA, L. F.; CARDOSO, M.A.C.; REGITANO, E.B. Ácaro da leprose Brevipalpus phoenicis (Gejskes, 1939): combate experimental em laranjeiras. Anais da Escola Superior de Agricultura Luiz de Queiroz, v.46, n.2, p.473-483, 1989.

MATINELLI, N.M.; OLIVEIRA, C.A.L.de; PERECIN, D. Conhecimentos básicos para estudos que envolvam levantamentos da população do ácaro Brevipalpus phoenicis (Geijskes, 1939) na cultura dos citros. Científica, v.4, p. 242-253, 1976.

MCCOY, C.W. Pathogens of eriophyoid mites. In: LINDQUIST, M.W.; SABELIS, M.W.; BRUIN, J. (Ed.) Eriophyoid mites: their biology, natural enemies and control. Amsterdan: Elsevier Sciense, 1996. cap. 2.4, p.481-490.

MCCOY, C.W. Pest control by the fungus Hirsutella thompsonii. In: BURGES, H.D. (Ed.). Microbial control of insects, mites and plant diseases. London: Academic Press, 1981. v.2, cap. 26, p.499-512.

MCCOY, C.W.; COUCH, T.L. Hirsutella thompsonii: a potencial mycoacaricide. Developments in Industrial Microbiology, v.20, p.89-96, 1978. 
MCCOY, C.W.; COUCH, T.L. Microbial control of the citrus rust mite with the mycoacaricide Mycar ${ }^{\circledR}$. Florida Entomologist, v.65, n.1, p.116-125, 1982.

MCCOY, C.; LYE, B. H. Effect of copper sprays on the population dynamics of the citrus rust mite, Phyllocoptruta oleivora (Acari: Eriophyidae) and its fungal pathogen, Hirsutella thompsonii. Proceedings of the Florida State for Horticultural Society, v.108, p.126-129, 1995.

MCCOY, C.W.; SAMSON, R.; BOUCIAS, D.C. Entomogenous fungi. In: IGNOFFO, C. (Ed.) Handbook of natural pesticides. Boca Raton: CRR Press, 1988. cap. 5, p.151-230.

MESUMECCI, M.R.; ROSSETTI, V. Transmissão de sintomas de leprose dos citros pelo ácaro Brevipalpus phoencis. Ciência e Cultura, v.15, n.3, p.228, 1963.

MEYER, M.K.P.S. Mite pests of crops in southern Africa. Pretoria: Departament of Agriculture and Fisheries, 1981. 92p. (Science Bulletin, 397).

MOINO JÚNIOR, A.; ALVES, S.B.; PEREIRA, R.M. Efficacy of Beuveria bassiana (Balsamo) Vuillemin isolates for control of stored-grain pests. Journal of Applied Entomology, v.122, p.301-305, 1998.

MOINO JÚNIOR, A.; ALVES, S.B.; LOPES, R.B.; NEVES, P.M.O.J.; PEREIRA, R.M.; VIEIRA, S.A. External development of the entomopathogenic fungi Beauveria bassiana and Metarhizium anisopliae in the subterranean termite Heterotermes tenuis Scientia Agricola, v.59, n. 2, p.267-273, 2002. 
MORAES, L.A.H.; BRAUN, J.; PORTO, O.M.; FINKLER, L.M.; GIMENEZ, P.R.M.; CAMERINI, C.C.; CONTE, M.O. Controle químico do ácaro da leprose Brevipalpus phoenicis (Geijskes, 1939) (Acari: Tenuipalpidae) em citrus. Pesquisa Agropecuária Gaúcha, v.1, n.1, p.7-11, 1995.

MULOCK, B.S.; CHANDLER, L.D. Beauveria bassiana transmission in western corn rootworm (Coleoptera: Chrysomelidae). The Canadian Entomologist, v.133, p.105-107, 2001.

MUMA, M.H. Factors contributing to the natural control of citrus insects and mites in Florida. Journal of Economic Entomology. v.48, p.432-438, 1955.

MUNGER, F.; GILMORE, J.E.; DAVIS, W.S. A disease of citrus red mites California Citrograph, v.44, p.190-216, 1959.

OCHOA, R.; AGUILAR, H.; VARGAS, C. Phytophagous mites of Central America: an illustrated guide. Turrialba: CATIE, 1994. 234 p.

ODUOR, G.I.; YANINEK, J.S.; DE MORAES, G.J.; VAN DER GEEST, L.P.S. The effect of pathogen dosage on the pathogenicity of Neozygites floridana (Zygomycetes: Entomophthorales) to Mononychellus tanajoa (Acari: Tetranychidae). Journal of Invertebrate Pathology, v.70, p.127-130, 1997.

OLIVEIRA, C.A.L. de. Ácaros dos citros. São Bernardo do Campo: Basf Brasileira, Departamento de Agroquímicos, 1994.18p.

OLIVEIRA, C.A.L.; NETO, R.R.C.; FERNANDES, C.B. Efeito de diferentes volumes de calda no controle do ácaro da leprose Brevipalpus phoenicis (Geijskes) em citros. Anais da Sociedade Entomológica do Brasil, v.27, n.1, p.117-124, 1998. 
OMOTO, C. Acaricide resistance management of leprosis mite (Brevipalpus phoenicis) in brazilian citrus. Pesticide Sciense, v.52, p.189-191, 1998.

OMOTO, C.; MCCOY, C. Toxicity of purified fungal toxin hirsutellin A to the citrus rust mite Phyllocoptruta oleivora (Ash.). Journal of Invertebrate Pathology, v.72, p.319-322, 1998.

OOMEN, P.A. Studies on population dynamics of the scarlet mite, Brevipalpus phoenicis, a pest of tea in Indonesia. Wageningen: Veenman \& Zonen, 1982. 88p.

PEÑA, J.E.; OSBORNE, L.S.; DUNCAN, R.E.; Potential of fungi as biocontrol agents of Polyphagotarsonemus latus (Acari: Tarsonemidae). Entomophaga, v.41, p.2736, 1996.

PIJNACKER, L.P.; FERWERDA, M.A.; BOLLAND, H.R.; HELLE, W. Haploid females parthenogenesis in the false spider mite Brevipalpus obovatus (Acari: Tenuipalpidae). Genetica, n.51, p. 211-214, 1980.

RAGA, A.; SATO, M.E.; CERAVOLO, L.C.; ROSSI, A.C.; SCARPELLINI, J.R. Ação de acaricidas sobre o ácaro da leprose Brevipalpus phoenicis (Geijkes, 1939) em pomar cítrico de Presidente Prudente (SP). Ecossistema, v.15, 1990.

RAMOS, E.Q. Seleção de isolados de fungos entomopatogênicos para o controle de Bemisia tabaci biótipo "B”. Piracicaba, 2001. 57p. Dissertação (mestrado) - Escola Superior de Agricultura “Luiz de Queiroz”, Universidade de São Paulo.

REED, D.K.; HALL, I.M. Electron microscopy of a rod-shaped non-inclusion virus afecting the citrus red mite, Panonychus citri. Journal of Invertebrate Pathology. v.20, p.272-278, 1972 
REIS, P.R. Ácaros de algumas fruteiras de clima tropical e subtropical e seus hospedeiros. Lavras: ESAL, 1994. 32p. (Boletim Técnico, Série Pesquisa, 3)

REIS, P.R.; SOUZA, J.C. de; SOUZA, E. de; TEODORO, AV. Distribuição espacial do ácaro Brevipalpus phoenicis (Geijskes) (Acari: Tenuipalpidae) em cafeeiro (Coffea arabica L.). Anais da Sociedade Entomológica do Brasil, v.29, n.1, p.177$183,2000$.

RENN, N.; BYWATER, A.F.; BARSON, G. A bait formulated with Metarhizium anisopliae for the control of Musca domestica L. (Dipt., Muscidae) assessed in largescale laboratory enclosures. Journal of Applied Entomology, v.123, p.309-314, 1999.

ROBERTS, D.W.; KRASNOFF, S.B. Toxinas e enzimas de fungos entomopatogênicos In: ALVES, S.B. (Ed.) Controle microbiano de insetos. Piracicaba: FEALQ, 1998. cap. 32, p.967-980.

RODRIGUES, J.C.V. Relações patógeno-vetor-planta no sistema leprose dos citros. Piracicaba, 2000. 168p. Tese (Doutorado) - Centro de Energia Nuclear na Agricultura, Universidade de São Paulo.

RODRIGUES, J.C.V.; BONATO, O.; NOGUEIRA, N.L. Population dynamics of Brevipalpus phoenicis on different citrus varieties in Brazil: II Influence of citrus variety. In: INTERNATIONAL CONGRESS OF ENTOMOLOGY, 21., Foz do Iguaçú, 2000. Abstracts. Londrina: EMBRAPA, CNPSo, 2000. Book 1, p.17.

RODRIGUES, J.C.V.; NOGUEIRA, N.L.; FREITAS, D.S.; PRATES, H.S. Virus-like particles associated with Brevipalpus phoenicis Geijkes (Acari: Tenuipalpidae), vector of citrus leprosis virus. Anais da Sociedade Entomológica do Brasil, v.26, n.2, p.391-395, 1997. 
RODRIGUES, J.C.V.; NOGUEIRA, N.L.; PRATES, H.S.; FREITAS, D.S. Leprose dos citros: importância, histórico, distribuição e relações com o ácaro vetor. Laranja, v.15, p.123-138, 1994.

ROSSETTI, V.; COLARICCIO, A.; CHAGAS, C.M.; SATO, M.E.; RAGA, A. Leprose dos citros. São Paulo: Sociedade Amigos do Instituto Biológico. (Boletim Técnico, 6). http://www.geocities.com/ esabio/leprose/leprose.htm (11 abr. 2002).

ROSSI, L.S.; ALVES, S.B.; TAMAI, M.A.; CASTIGLIONI, E. Patogenicidade de Beauveria bassiana ao ácaro Phyllocoptruta oleivora Ashmed. In: SIMPÓSIO DE CONTROle BIOLÓGiCO, 7., Poços de Caldas, 2001. Resumos Lavras: UFLA, 2001. p.352.

SALVA, R.A.; MASSARI, C.A. Situação do ácaro da leprose no estado de São Paulo (Levantamento - Fundecitros Agosto 1995). In: OLIVEIRA, C.A.L. de; DONADIO, L.C. (Ed.) Leprose dos citros. Jaboticabal: FUNEP, 1995. p.13-18.

SELHIME,A.G.; MUMA, M.H. Biology of Entomophthora floridana attacking Eutetranychus banksi. Florida Entomologist, v.49, n.3, p.161-168, 1966.

SEWIFY,G.H.; MABROUK, A.M. The susceptibility of different stages og the citrus brown mite, Eutetranychus orientalis Oudemans (acarina: Tetranychidae) to the entomopathogenic fungus, Verticillium lecanii (Zimm.) Viégas. In: INTERNATIONAL COLLOQUIUM OF INVERTEBRATE PATHOLOGY AND MICROBIAL CONTROL, 5., Adelaide, 1990. Proceedings and abstracts. Adelaide: SIP, 1990. p.395. 
SHAW, J.G.; TASHIRO, H.; DIETRICK, E.D. Infection of the citrus red mite with virus in central and southern California. Journal of Economic Entomology, v.61, n.6, p.1492-1495, 1968 a.

SHAW, J.G.; CHAMBERS, D.L.; TASHIRO, H. Introducing and establishing the noninclusion virus of the citrus red mite in citrus groves. Journal of Economic Entomology, v.61, n.5, p.1352-1355, 1968 b.

SHAW, K.E.; DAVIDSON, G.; CLARK, S.J.; BALL, B.V.; PELL, J.K.; CHANDLER, D.; SUNDERLAND, K.D. Laboratory bioassays to assess the pathogenicity of mitosporic fungi to Varroa destructor (Acari: Mesostigmata), na ectoparasitic mite of the honeybee, Apis mellifera. Biological Control, v.24, p.266-276, 2002.

SMITH, K.M.; HILL, G.J.; MUNGER, F.; GILMORE, J.E. A suspected virus disease of the citrus red mite Panonychus citri. Nature, v. 184, p.70, 1959

SMITLEY, D.R.; BROOKS, W.M.; KENNEDY, G.G. Enviromental effects on production of primary and secondary conidia, infection nad pathogenesis of Neozygites floridana, a pathogen of the twospotted spider mite, Tetranychus urticae. Journal of Invertebrate Pathology, v. 47, p.325-332, 1986.

SOSA-GÓMES, D.R.; NASCA, A.J. A primera cita del hongo patógeno de ácaros, Hirsutella thompsonii (Fisher, 1950) para la República Argentina. CIRPON Revista de Investigacíon, v.1, n.3, p.137-141, 1983.

SOSA GÓMEZ, D.R.; RICCI, J.G.; NASCA, A.J. Efecto de Hirsutella thompsonii Fisher var. thompsonii, sobre larvas y adultos de Coccidophilus citricola Brethes y Lindorus lophanthae (Blaisdell) (Col.: Cocinellidae). CIPRON - Revista de Investigacíon, v.3, n.1/2, p.73-77, 1985. 
SOSA-GÓMEZ; TIGANO, M.S.; ARANTES, O.M.N. Caracterização de entomopatógenos. In: ALVES, S.B. (Ed.) Controle microbiano de insetos. Piracicaba: FEALQ, 1998. cap. 22, p.731-758.1998.

SPEARS, A.T.; YOTHERS, W.W. Is there na entomogenous fungus attacking the citrus rust mite in Florida? Science, v.11, p.41-42, 1924.

STIMAC, J.L.; ALVES, S.B.; CAMARGO, M.T.V. Controle de Solenopsis spp. (Hymenoptera: Formicidae) com Beauveria bassiana (Bals.) Vuill. em condições de laboratório e campo. Anais da Sociedade Entomológica do Brasil, v.18, p.95-103, 1989.

TAMAI, M.A. Avaliação de fungos entomopatogênicos para o controle de Tetranychus urticae Koch. Piracicaba, 1998. 86p. Dissertação (Mestrado) - Escola Superior de Agricultura “Luiz de Queiroz”, Universidade de São Paulo.

TAMAI, M.A. Controle de Tetranychus urticae Koch com fungos entomopatogênicos. Piracicaba, 2002. 144p. Tese (Doutorado) - Escola Superior de Agricultura "Luiz de Queiroz", Universidade de São Paulo.

TAMAI, M. A.; ALVES, S.B.; NEVES, P.J. Patogenicidade de Beauveria bassiana (Bals.) Vuill. ao ácaro Tetranychus urticae Koch. Scientia Agricola, v.56, n.1, p.285-288, 1999.

TANADA, Y.; KAYA, H.K. Epizootiology. In: TANADA, Y.; KAYA, H.K. (Ed.) Insect pathology. San Diego: Academic Press, 1993. cap. 16, p.595 - 622.

TANZINI, M.R. Controle do percevejo-de-renda-da-seringueira (Leptotharsa heveae) com fungos entomopatogênicos. Piracicaba, 2002. 140p. Tese (Doutorado) Escola Superior de Agricultura “Luiz de Queiroz”, Universidade de São Paulo. 
TANZINI, M.R.; ALVES, S.B.; MORAES, G.J.; TAMAI, M.A.; FERLA, N.J. An epizootic of Calacarus heveae (Acari: Eriophyidae) caused by Hirsutella thompsonii F. on rubber trees. Experimental and Applied Acarology, v.24, n.2, p.141-144, 2000 .

TASHIRO,H.; BEAVERS, J.B. Field epizootic of the citrus red mite virus disease California Citrograph, v.51, n. 12, p.503-506, 1966.

TRINDADE, M.L.B.; CHIAVEGATO, L.G. Caracterização biológica dos ácaros Brevipalpus obovatus D., B. californicus B. e B. phoenicis G. (Acari: Tenuipalpidae). Anais da Sociedade Entomológica do Brasil, v.23, n.2, p.189$195,1994$.

VAN DER GEEST, L.P.S.; ELLIOT, S.L.; BREEUWER, J.A.J.; BEERLING, E.A.M. Disease of mites. Experimental and Applied Acarology, n.24, p.497-560, 2000.

VELOSO, V.R.S.; SILVA, A.L.; SANCHEZ, S.E.M.; ROCHA, M.R. Controle químico do ácaro Brevipalpus phoenicis (Geijskes, 1939), transmissor da leprose em ditros. Anais da Escola de Agronomia e Veterinária de Goiânia, v. 18, n.1, p.141-149, 1988.

VEY, A.; QUIOT, J.M.; MAZET, I.; McCOY, C.W. Toxicity and pathology of crude broth filtrate produced by Hirsutella thompsonii var. thompsonii in shake culture. Journal of Invertebrate Pathology, v.61, p.131-137, 1993.

WEEKS, A.R.; MAREC, F.; BREEUWER, J.A. A mite species that consists entirely of haploid females. Sciense, v.292, p. 2479-2481, 2001. 
WEISER, J.; MUMA, M.H. Entomophthora floridana n.s. (Phycomycetes: Entomophthoraceae), a parasite of the Texas citrus mite Tetranychus banksi. Florida Entomologist, v.49, n. 3, p.155-159, 1966.

WILDING, N. Pest control by Entomophthorales. In: BURGES, H.D. (Ed.). Microbial control of pest and plant diseases. London: Academic Press, 1981. cap.28, p.539554.

WRAIGHT, S.P.; BUTT, T.M., GALAINI-WRAIGHT, S; ALLEE, L.L.; SOPER, R.S.; ROBERTS, D.W. Germination and infection processes of the entomophthoralean fungus Erynia radicans on the potato leafhopper, Empoasca fabae. Journal of Invertebrate Pathology, v.56, p.157-174, 1990.

YANINEK, J. S.; MORAES, G. A synopsis of classical biological control of mites in agriculture. In: DUSBABECK, F.; BUKVA, V. (Ed.). Modern acarology. Prague: SPB Academic Publ., 1991. cap.1, p.133-149.

YOUNG, S.S.Y.; YEHLING, D.M.; SASTRODIHARDJO, S.; WRENSCH, D.L. Sampling population density of Brevipalpus phoenicis (Acari: Tenuipalpidae) and assessment of feeding damage level on Indonesian tea. Journal of Economic Entomology, v. 88, n.2, p.283-287, 1995.

ZOEBISCH, T.G.; OCHOA, R.; VARGAS, C.; GAMBOA, A. Identification y potencial del hongo Hirsutella thompsonii Fisher para el control de acaros de importancia economia en America Central. Manejo Integrado de Plagas, v.23, p.9$12,1992$. 